\title{
CONSUMO DE ÁGUA POR CULTURA DE CITROS CULTIVADA EM LATOSSOLO VERMELHO AMARELO
}

\section{ANTÔNIO CARLOS RODRIGUES CRUZ}

Tese apresentada à Escola Superior de Agricultura "Luiz de Queiroz", Universidade de São Paulo, para obtenção do título de Doutor em Agronomia, Área de Concentração: Solos e Nutrição de Plantas.

\author{
PIR A C ICABA \\ Estado de São Paulo - Brasil \\ Fevereiro - 2003
}




\section{CONSUMO DE ÁGUA POR CULTURA DE CITROS CULTIVADA EM LATOSSOLO VERMELHO AMARELO}

\section{ANTÔNIO CARLOS RODRIGUES CRUZ}

Engenheiro Agrônomo

Orientador: Prof. Dr. PAULO LEONEL LIBARDI

Tese apresentada à Escola Superior de Agricultura "Luiz de Queiroz", Universidade de São Paulo, para obtenção do título de Doutor em Agronomia, Área de Concentração: Solos e Nutrição de Plantas.

PIRACICABA

Estado de São Paulo - Brasil

Fevereiro - 2003 
Dados Internacionais de Catalogação na Publicação (CIP) DIVISÃO DE BIBLIOTECA E DOCUMENTAÇÃO - ESALQ/USP

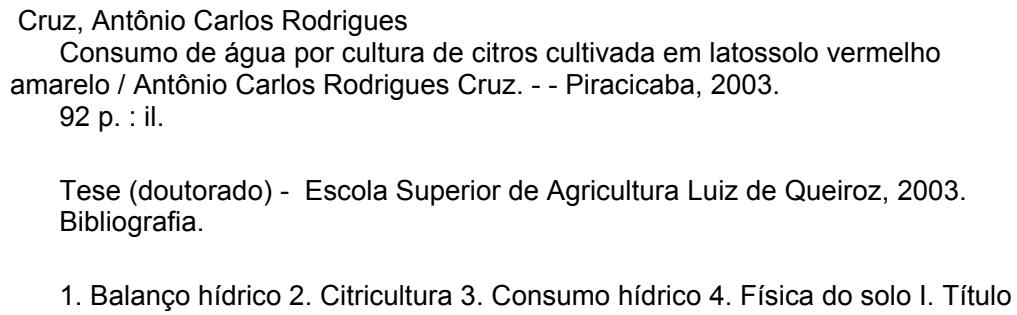

CDD 634.3 


\section{DEDICO}

A Deus por me manter com saúde.

Aos meus pais, Fernando e llca pela amizade, amor, e constante incentivo durante todos momentos de minha vida. 


\section{AGRADECIMENTOS}

Ao professor Dr. Paulo Leonel Libardi pela orientação, ensinamentos e amizade durante o curso.

Aos professores Sérgio de Oliveira Moraes, Nilson Augusto Villa Nova, Quirijn de Jong van Lier e Antonio Roberto Pereira, pela amizade e incentivo.

Ao Prof. Dr. Godofredo César Vitti pela amizade e exmplo de dedicação à docência.

Aos professores do Departamento de Solos e Nutrição de Plantas responsáveis por minha formação e atualização dos meus conhecimentos.

Ao colega e amigo Luciano L. de Toledo Piza, pela amizade e companheirismo durante todos os momentos da realização deste trabalho.

Aos colegas de pós-graduação pelo convívio durante o curso em especial: Roberto Wagner, Jonas Russhel, Ricardo Romero, Márcia Toffany.

Aos colegas que contribuíram de diversas formas para a realização deste trabalho: Genelício, Laércio, Rogério, Ana Lúcia, Claudia Lima, Herdjania, Elias, Flávia, Luciana Castro, Claudia Teixeira, José Fernandes e Jean.

Aos funcionários do Laboratório de Física do Solo do Departamento de Física e Meteorologia, Francisco Bernardo Dias e Luiz Fernando Novello.

Ao amigo Jorge A. Wiendl pelas contribuições em informática e pelas conversas sempre produtivias.

Às bibliotecárias Eliana M. Garcia e Kátia M. de Andrade Ferraz, da DIBD/ESALQ/USP, pela revisão das referências bibliográficas.

Ao CNPq pela concessão da bolsa de estudo.

A CAPES, por meio do Projeto 0095/00-1 do PROCAD - 2000, do qual o presente trabalho faz parte.

Ao Departamento de Produção Vegetal da ESALQ/USP pela permissão da montagem do experimento em sua área experimental. 
Á minha família que sempre foi incentivadora de minha carreira profissional, meus pais, Fernando e Ilca, e meus irmãos, Julio César, Maria Lucia e Fernando Luiz. 


\section{SUMÁRIO}

Página

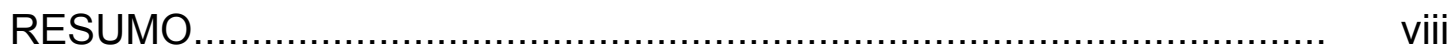

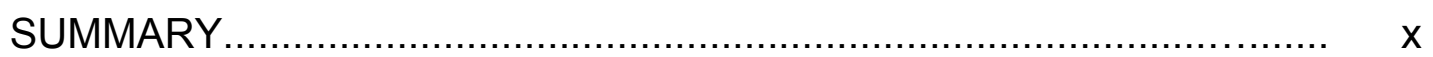

1 INTRODUÇÃO......................................................................... 1

1.1 Justificativa............................................................................... 2

1.2 Objetivo............................................................................... 2

2 REVISÃO DE LITERATURA....................................................... 3

2.1 Balanço hídrico ........................................................................ 5

2.2 Fatores hídricos que influenciam na adaptação de espécies de

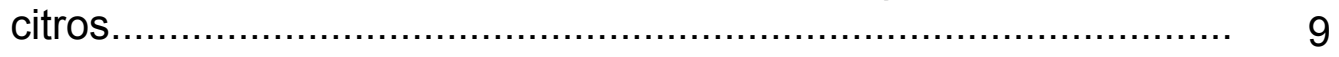

2.3 Estimativa do consumo de água do solo para citros......................... 11

2.4 Solos e sistema radicular de citros................................................. 15

2.5 Extração de água por raízes de culturas.......................................... 18

2.6 Estatística descritiva e análise exploratória de dados....................... 19

3 MATERIAL E MÉTODOS.............................................................. 23

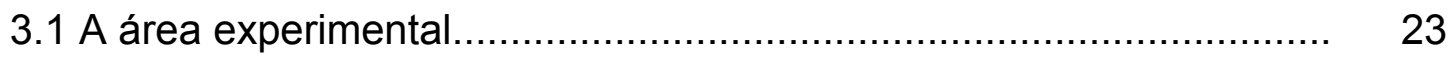

3.1.1 Localização............................................................... 23

3.1.2 Clima

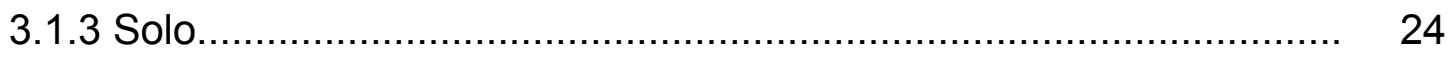

3.1.4 Descrição da cultivar......................................................... 24

3.2 Caracterização hidráulica do solo................................................. 25

3.2.1 Curvas de Retenção................................................................ 25

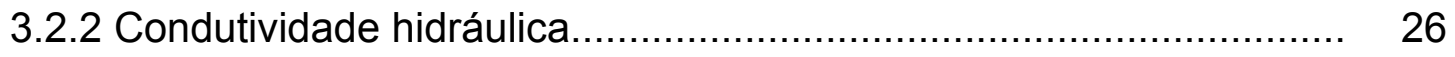

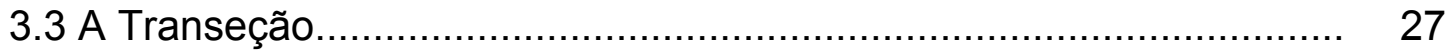


3.4 Tensiômetros e tubos de acesso para sonda de nêutrons................ 28

3.5 Avaliação da Evapotranspiração do Citros.................................... 29

3.5.1 Precipitação.............................................................. 30

5.2 Irrigação.......................................................................... 30

3.5.3 Deflúvio superficial.................................................... 31

3.5.4 Drenagem interna ou ascensão capilar................................. 31

3.5 .5 Evapotranspiração........................................................... 32

3.5.6 Variação de armazenagem.............................................. 33

3.6 Eficiência de uso da água................................................ 34

3.7 Detalhamento de uma planta............................................... 34

3.8 Análise estatística dos dados.......................................... 37

3.8.1 Resumo estatístico....................................................... 37

3.8.2 "Resumo de 5-números"................................................ 37

3.8.2.1 Medidas de Posição e Dispersão........................................ 38

3.8.3 "Boxplots" .............................................................. 38

4 RESULTADOS E DISCUSSÃO ........................................... 40

4.1 Experimento do balanço hídrico no campo.................................. 41

4.1.1 Análise exploratória dos dados.......................................... 41

4.1.2 Os processos do balanço................................................. 49

4.2 Experimento de extração de água por uma planta de citros............ 59

4.3 Outras considerações...................................................... 67

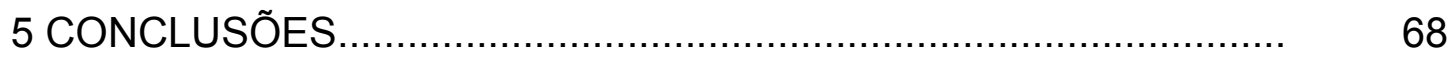

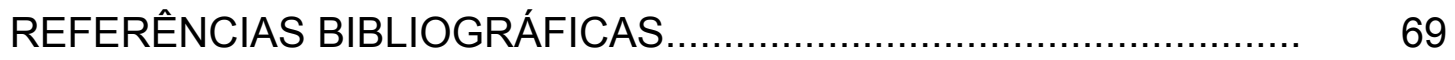

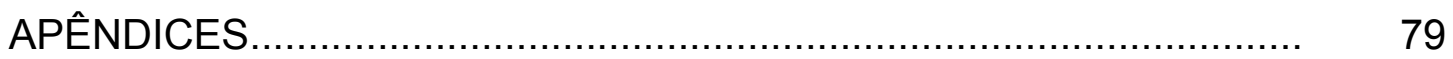




\title{
CONSUMO DE ÁGUA POR CULTURA DE CITROS CULTIVADA EM LATOSSOLO VERMELHO AMARELO
}

\author{
Autor: ANTÔNIO CARLOS RODRIGUES CRUZ \\ Orientador: Prof. Dr. PAULO LEONEL LIBARDI
}

\section{RESUMO}

A produção das culturas e, particularmente neste estudo, a de citros, associada às condições climáticas e edáficas, é função da presença de água e nutrientes no solo em época e quantidades apropriadas. Sua falta ou excesso é fator limitante à produção, determinando em muitos casos a sua diminuição. $O$ objetivo do presente trabalho foi a avaliação do consumo de água de pomares de citros em Latossolo Vermelho-Amarelo Distrófico argissólico, pela determinação do balanço hídrico no solo, na busca de explicar cientificamente o comportamento hídrico dessa cultura neste solo ao longo do ano agrícola e a influência do consumo de água sobre a produtividade da cultura. $\mathrm{O}$ balanço hídrico foi conduzido em duas transeções com 20 plantas e $100 \mathrm{~m}$ de

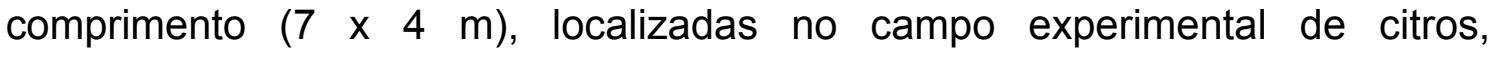
Departamento de Produção Vegetal, Esalq/USP, município de Piracicaba (SP). A condutividade hidráulica para a profundidade controle $(1,10 \mathrm{~m})$ foi determinada pelo método do perfil instantâneo conduzido em área adjacente. $\mathrm{O}$ armazenamento foi determinado com o uso de sonda de nêutrons. A drenagem 
interna e/ou ascensão capilar foi medida pela leitura diária de três tensiômetros instalados na projeção da copa (2 $\mathrm{m}$ do tronco) das 40 plantas em três profundidades: $1,00 \mathrm{~m}, 1,10 \mathrm{~m}$ e 1,20 m. A precipitação pluvial foi medida por pluviôgrafo instalado na área e foi considerada normal para o período do ano monitorado (agosto-agosto). A extração de água por uma planta do pomar também foi medida pela instalação de tensiômetros nas profundidades $0.2 \mathrm{~m}$, $0.4 \mathrm{~m}, 0.6 \mathrm{~m}, 0.8 \mathrm{~m}$ e $1.0 \mathrm{~m}$ e a $0.4 \mathrm{~m}, 0.8 \mathrm{~m}, 1.2 \mathrm{~m}, 1,6 \mathrm{~m}$ e $2.0 \mathrm{~m}$ do tronco em direção à linha e em direção à entrelinha. A evapotranspiração da cultura (ETc) média desta comunidade de plantas foi de $1271 \mathrm{~mm}$, sendo a variação da ETc diária entre 0,4 e 8,3 $\mathrm{mm} \mathrm{dia}^{-1}$ e a razão ETc/ECA variando entre 0,3 e 1,5 para os meses de menor e maior necessidade hídrica. A camada de 0,40 à 0,60 m de profundidade mostrou ser que a cultura de citros apresenta maior volume de raízes. Em futuros projetos de irrigação por gotejadores (irrigação localizada) para a cultura de citros, a distância de $0,40 \mathrm{~m}$ do tronco deve ser a adotada para a obtenção da melhor eficiência. 


\title{
CITRUS ORCHARD WATER USE IN A LATOSSOLO VERMELHO AMARELO (OXISOL)
}

\author{
Author: ANTÔNIO CARLOS RODRIGUES CRUZ \\ Adviser: Prof. Dr. PAULO LEONEL LIBARDI
}

\section{SUMMARY}

The agricultural yield and, particularly in this study, the citrus yield, associated to weather and soil conditions, is dependent on the presence of water and nutrients in the soil in appropriate amounts along the time. Its lack or excess is a limiting factor to the production, determining in many cases its decrease. The objective of the present work was to evaluate the water consumption by citrus orchards in a Latossolo Vermelho Amarelo(Oxisol), by the means of the soil water balance determination aiming at the scientific explanation of the hydric behavior of this crops in this soil, along the agricultural year, and the influence of the water consumption on the crop productivity. The soil water balance was determined in two transects, $100 \mathrm{~m}$ length $(7 \times 4 \mathrm{~m})$ and 20 plants each, located at the experimental fields of the Vegetable Crop Department, Esalq/USP, Piracicaba (SP - Brazil). The hydraulic conductivity for the control depth $(1,10 \mathrm{~m})$ was determined by the instantaneous profile method carried out in an adjacent area. The water storage was measured by a neutron probe. The internal drainage and/or capillary rise was measured by the daily reading of three tensiometers installed under each one of the 40 trees $(2 \mathrm{~m}$ from 
stem) at three depths: $1.00 \mathrm{~m}, 1.10 \mathrm{~m}$ and $1.20 \mathrm{~m}$. The rainfall was measured by means of a pluviographer installed in the area and it was considered normal for the period of the monitored year (August-August). Water extraction of one plant of the orchard was also assessed installing tensiometers at the depths $0.2 \mathrm{~m}$, $0.4 \mathrm{~m}, 0.6 \mathrm{~m}, 0.8$ and 1.0 and $0.4 \mathrm{~m}, 0.8 \mathrm{~m}, 1.2 \mathrm{~m}, 1.6 \mathrm{~m}$ and 2,0 from the stem along and perpendicular to the plants line. The annual evapotranspiration of the crop (Etc) was $1271 \mathrm{~mm}$ and the daily one varied from 0.4 to $8.3 \mathrm{~mm} \mathrm{dia}^{-1}$. The ETC/ECA ratio varied from 0.3 to 1.5 for the months with lowest and highest water need. The soil layer in which the citrus presented the highest volume of roots was $0,40-0,60 \mathrm{~m}$. In future drip irrigation projects (trickle irrigation) for the citrus, the distance of $0.40 \mathrm{~m}$ from stem should be adopted to obtain the highest irrigation efficiency. 


\section{INTRODUÇÃO}

O Brasil é, atualmente, o maior produtor mundial de citros, com produção em 2001 de aproximadamente 18 milhões de toneladas, seguido dos EUA, México e Espanha. A produção de citros do Estado de São Paulo corresponde à cerca de $75 \%$ da produção nacional. Nos últimos 20 anos esta cultura experimentou notável desenvolvimento graças à adoção de melhor tecnologia na condução dos pomares, ao maior potencial genético representado pelos clones nucelares e ao programa de plantas matrizes selecionadas.

A produção das culturas e, particularmente neste estudo, a de citros, associada às condições climáticas e edáficas, é função da presença de água e nutrientes no solo em época e quantidades apropriadas. Sua falta ou excesso é fator limitante à produção, determinando em muitos casos a sua diminuição. $O$ conhecimento da quantidade de água retirada do solo pelos vegetais é de grande interesse, principalmente, para os estudos sobre a economia hídrica das culturas.

O consumo de água pela cultura de citros em Latossolo VermelhoAmarelo foi a preocupação maior do trabalho, cuja quantificação levou a um maior aprofundamento da água nesse sistema solo-planta-atmosfera.

A elaboração do balanço hídrico da cultura de citros nesta classe de solo poderá, portanto, além de fornecer dados sobre as necessidades hídricas desta comunidade vegetal, caracterizá-la do ponto de vista do regime hídrico regional. 


\subsection{Justificativa}

A idéia geral deste trabalho foi identificar, cientificamente, o comportamento hídrico das plantas de citrus com o tempo e mostrar as diferenças no consumo de água, para a classe Latossolo Vermelho-Amarelo a partir de determinações de balanços de água no solo. Paralelamente a isto foi avaliada a extração de água por uma árvore do pomar, na tentativa de avaliar o comportamento radicular no que diz respeito à absorção de água. Este conhecimento servirá de base para futuras implantações de pomares em solos como o agora estudado, bem como para futuros estudos de viabilidade de irrigação para esta cultura, nestas condições.

\subsection{Objetivo}

O objetivo do presente trabalho foi avaliar o consumo de água por citros em Latossolo Vermelho-Amarelo, pela determinação do balanço hídrico no solo e, com isso, explicar o comportamento da água neste solo, ao longo do ano agrícola, além de avaliar, também a influência do consumo de água sobre a produtividade da cultura. 


\section{REVISÃO DE LITERATURA}

O gênero Citrus é o mais importante da Família Rutaceae, existindo numerosas espécies cultivadas em caráter comercial, como as laranjas tangerinas, limões, limas, cidras, pomelos e outras. Destacam-se várias espécies como a Citrus sinensis L. Osbeck., Citrus deliciosa Tenore, Citrus aurantifolia Swingle, Citrus latifólia Tanaka, Citrus limon Burn.e Citrus paradisi Macfadyen. Estas plantas cítricas são originárias de regiões úmidas tropicais e subtropicais do continente asiático e foram introduzidas no Brasil quando da colonização do país, provavelmente pela Bahia (Figueiredo, 1991).

O Brasil é, atualmente, o maior produtor mundial de citros, com produção em 2001 de aproximadamente 18 milhões de toneladas, seguido dos EUA, México e Espanha. A cultura encontra-se disseminada por todo o território nacional, com grande importância econômica e social para diversos estados da federação, nos quais se situa entre as dez principais culturas: São Paulo $( \pm 14$ milhões de toneladas), Sergipe ( \pm 900 mil toneladas), Rio de Janeiro ( \pm 170 mil toneladas), Minas Gerais ( \pm 450 mil toneladas), Rio Grande do Sul $( \pm 400$ mil toneladas) e Bahia ( \pm 900 mil toneladas) (FNP, 2002).

Conforme os dados citados, a produção de citros do Estado de São Paulo corresponde à cerca de $75 \%$ da produção nacional. Nos últimos 20 anos esta cultura experimentou notável desenvolvimento graças à adoção de melhor tecnologia na condução dos pomares, ao maior potencial genético representado pelos clones nucelares e ao programa de plantas matrizes selecionadas. Dentro do Estado destacam-se como maiores produtores, os municípios de Bebedouro, Itápolis, Limeira, Taquaritinga, Monte Azul Paulista, Olímpia, Colina, Matão e 
Araraquara. O que tem sido verificada é uma diversificação nas áreas de plantio, visto não depender mais da proximidade de fábrica de suco. Em vista dessa situação, vem se tornando freqüente o interesse da prática da irrigação que, nas plantações mais tecnificadas, é dirigida para a comercialização de frutas frescas.

A exploração de citros é desenvolvida, em sua grande maioria, sob condições de sequeiro, com isso o suprimento de água se constitui num dos principais fatores limitantes à produção desta cultura. Nesse contexto, os estudos relacionados à influência do ambiente sobre a cultura de citros devem priorizar a avaliação dos efeitos dos fatores do clima o uso e perdas de água pelas plantas e sobre o regime hídrico do solo (Reuther, 1973).

A água no solo está sempre submetida a processos dinâmicos e para melhor caracterizar o tipo de manejo a ela imposto, ou a uma cultura, faz-se necessário quantificar os parâmetros do solo, planta e clima, influentes nestes processos. A magnitude das resistências ao movimento da água no sistema solo-planta-atmosfera varia em função do tipo de solo, demanda evaporativa da atmosfera e características vegetais, que são, portanto, fatores essenciais aos estudos de fisiologia vegetal, irrigação e agrometeorologia, entre outras, ou mesmo para a análise da produtividade vegetal (Brunini, 1987).

A capacidade de armazenamento de água no solo disponível para o desenvolvimento das culturas é função de parâmetros fisico-hídricos do solo e da profundidade do sistema radicular (Villa Nova, 1982). O regime hídrico do solo e a disponibilidade de água às plantas são fator importante quando um solo é avaliado como potencialmente produtivo para determinada cultura. A quantidade de água absorvida pelas plantas não depende apenas do conteúdo ou potencial total da água no solo, mas também de sua capacidade em transmitir esta água para as plantas (Hillel, 1970). Para Reichardt (1978) esta capacidade ou esta dinâmica da água no solo depende de inúmeros fatores como heterogeneidade do perfil, tipo de planta e condições atmosféricas, entre 
outras, e seu conhecimento durante o desenvolvimento da cultura é essencial para o aprimoramento de práticas de manejo.

\subsection{Balanço hídrico com ênfase no armazenamento da água no solo}

O consumo de água pelas comunidades vegetais é um parâmetro importante a ser considerado nos estudos de regionalização agrícola ou na avaliação da produtividade das culturas. Uma forma pela qual esse consumo hídrico (evapotranspiração) pode ser determinado é pelo balanço hídrico no solo.

Para prover as disponibilidades hídricas no solo necessárias à agricultura, e aqui particularmente à cultura dos citros, não basta considerar os dados pluviométricos do período. Estes correspondem apenas ao processo de suprimento de água para o uso das plantas. É necessário considerar também os processos de perda de água do solo para a atmosfera fazendo-se o balanço hídrico da água no solo (Camargo, 1987).

Nesses balanços contábeis, o solo funciona como reservatório de água; a chuva ou a irrigação, como entrada, e a evapotranspiração como saída de água (Camargo, 1987). O conhecimento de como as plantas utilizam a água do solo e de como respondem aos níveis de armazenagem é feito a partir do já citado balanço hídrico. O movimento cíclico da água no pomar começa com a infiltração no solo, continua com o seu armazenamento temporário na região do sistema radicular e termina com a sua remoção do solo por meio da drenagem, da evaporação e da absorção pelas raízes (Hillel, 1970).

O processo de contabilidade hídrica mais utilizado para fins climatológicos é o método de Thornthwaite \& Mather (1955), que consiste no cotejo entre a precipitação pluviométrica e a evapotranspiração, considerandose uma determinada capacidade de retenção de água pelo solo, bem como em função do tipo de cobertura vegetal (Ortolani \& Camargo, 1987).

A metodologia do balanço hídrico num volume de controle de solo tem sido apresentada por vários autores (Rose \& Stern, 1965; Rose, 1966; Slatyer, 
1967; Guandique \& Libardi, 1997; Reichardt et al., 1979), sendo seus componentes (precipitação, irrigação, evapotranspiração, deflúvio superficial, drenagem/ascensão capilar e variação do armazenamento de água no solo) apresentados numa forma integral ou diferencial numa equação geral de balanço de massa. Atualmente a ênfase destes balanços tem sido dada à disponibilidade de água no solo relacionada com elementos climáticos e com o desenvolvimento vegetal. A disponibilidade de água no solo, não se baseia apenas em dados de precipitação pluvial, também é necessário levar em conta as perdas de água no solo para a atmosfera, que se verificam normalmente pela perda de água por evaporação mais transpiração vegetal (Andreatta, 1990). A determinação desses componentes é feita por técnicas e meios diferentes.

A precipitação é medida com considerável precisão por pluviômetros ou pluviógrafos. O principal problema consiste na representatividade de dados coletados numa estação meteorológica. Sua distância à cultura onde se realiza o balanço é de fundamental importância, sendo recomendável que a medida da chuva seja feita o mais próximo possível da área experimental.

Outro elemento do balanço hídrico é o deflúvio superficial ou run-off. Segundo Rose (1966), a medida do deflúvio superficial é feita por meio de técnicas e estruturas apropriadas, mas em algumas ocasiões as medidas diretas se tornam difíceis devido ao volume de água envolvido, e à variação com a declividade.

Quando a água é perdida devido a movimentos descendentes dentro do perfil do solo, saindo da zona explorada pelo sistema radicular, ocorre a drenagem interna. Dependendo do tipo de solo, de suas condições de umidade e da precipitação pluvial, as perdas por drenagem interna podem ser consideráveis. Em certos períodos pode chegar até a $60-70 \%$ da precipitação, embora também, muitas vezes, seja desprezível (Oliveira, 1991).

Os fluxos de água no solo na profundidade considerada (L) e a variação de armazenamento de água numa camada de profundidade $0-L$, são 
fatores tipicamente de solo. Variam de classe de solo para classe de solo, e dependem da heterogeneidade do perfil e de todos os outros componentes do balanço.

O fluxo de drenagem interna ou ascensão capilar é o componente de mais difícil determinação, motivo pelo qual tem sido freqüentemente desprezado e incluído como parte do armazenamento ou da evapotranspiração (Rose, 1966). No entanto, segundo Vauchaud et al. (1985) e Stone et al. (1973), esse componente não é sempre desprezível, podendo constituir $30 \%$ ou mais do balanço hídrico total, principalmente em regiões de clima tropical. Brunini et al. (1981) afirma que a componente drenagem é um fator importante no balanço, pois, em lavoura de arroz, pode chegar a mais de $90 \%$ da variação total do armazenamento de água no solo.

Van Genuchten \& Nielsen (1985) fazem uma excelente revisão sobre as várias equações encontradas na literatura que representam a curva de retenção da água no solo e sua utilização para descrever a função $K(\theta)$. São citados pelos autores, os modelos de Brook \& Corey (1964), Visser (1968), Laliberte (1969) e Van Genuchten (1980). As curvas de retenção, graficamente, variam de acordo com as características físicas do solo (Gardner, 1983), principalmente textura e estrutura. Van Genuchten (1980), com base no modelo de Mualem (1976), propôs uma equação que descreve a condutividade hidráulica relativa do solo, utilizando os dados da curva de retenção.

Vauclin et al. (1982) estudaram os métodos de Libardi et al. (1980) e Van Genuchten (1980) para a avaliação da condutividade hidráulica de solos e concluíram que, apesar de ter representado bem os dados da função $\theta\left(\phi_{m}\right)$, o modelo de Van Genuchten (1980), superestimou os valores da função $K(\theta)$, já o modelo de Libardi et al. (1980) subestimou os dados da função $K(\theta)$, mas facilitou seu cálculo por só utilizar os valores de umidade do processo de redistribuição de água. Entre os atributos do solo influentes no processo de condutividade hidráulica, a textura é uma das características importantes, devido a sua grande correlação com outros atributos ou com fenômenos que 
ocorrem no solo. A taxa de infiltração da água no solo, a capacidade de retenção de água e de nutrientes, é amplamente influenciadas pela composição granulométrica dos solos.

Para a quantificação do armazenamento de água num solo cultivado deve-se levar em consideração uma camada que envolve todo o volume explorado pelo sistema radicular da cultura. Em função da profundidade considerada $(L)$, e para uma dada profundidade, ele varia em função do tempo devido a processos de ganho de água (chuva e/ou irrigação) e de perdas (evapotranspiração e/ou drenagem interna). Este armazenamento de água é determinado a partir da integração dos perfis de umidade do solo. Esses normalmente têm sido obtidos gravimetricamente (Van Bavel et al., 1968), pela moderação de nêutrons (Reichardt et al., 1974; Turatti et al., 1990), ou ainda pela combinação dos dois (Stone et al., 1973).

Mais recentemente aplicação da técnica de TDR para medida do conteúdo de água no solo tem sido bastante utilizada para estudos de campo e laboratório. Esta técnica utiliza a constante dielétrica da água para estimar o conteúdo de água do solo. Um dos trabalhos precursores nessa linha foi o de Topp et al. (1980), que mostraram a aplicação do método para medir o conteúdo volumétrico de água de cinco solos. Segundo Teixeira (2001), apesar dos avanços tecnológicos aplicados à técnica, os estudos disponíveis no Brasil ainda são poucos, principalmente relacionados à calibração, à sensibilidade da medida e à comparação com outros equipamentos para medida do conteúdo de água. Parte dos estudos devem estar voltados às diferentes características de nossos solos que podem interferir nas medidas, como textura, matéria orgânica, teor de óxidos etc.

Embora em uso já por mais de quatro décadas, não foi possível estabelecer critérios satisfatórios para a calibração do método de moderação de nêutrons, sendo esta uma de suas desvantagens. São relatados que vários fatores, como densidade do solo, mineralogia, $\mathrm{pH}$, porosidade e matéria orgânica afetam largamente a calibração da sonda de nêutrons (Holmes \& 
Jenquinson, 1959; Lal, 1974; Turatti et al., 1990). Turatti et al. (1990) verificaram que a variabilidade do solo foi o principal fator que afetou a calibração da sonda, devido, principalmente, à umidade, à porosidade e à densidade do solo, apresentando um coeficiente de regressão igual a 0,86.

\subsection{Fatores hídricos que influenciam na adaptação de espécies de citros}

A maioria das plantas cítricas e os gêneros relacionados são plantas que retêm a água e são capazes de resistir a períodos longos de seca quando se trata de árvores adultas. Esta capacidade de reter água é devida a uma combinação de fatores anatômicos e fisiológicos que limitam o movimento de água na planta (Davies \& Albrigo, 1994). A folhas das plantas cítricas são também adaptadas a conservar água. Seus estômatos controlam fracamente a perda de água em plantas jovens, mas são muito eficientes em plantas adultas (Smalstrla \& Koo, 1997).

A eficiência do uso da água nos citros é bastante baixa quando comparada a outras plantas C3. Seu fruto por possuir casca coriácea, com baixa densidade estomática e altos níveis de cera, contribuem também para a conservação total de água da árvore. A fruta serve como depósito de água para as folhas durante os períodos secos. Por esta razão, plantas com frutos resistem mais a períodos secos que plantas sem frutos.

Neste contexto, o propósito da irrigação em pomares de citros é minimizar os efeitos perniciosos do estresse hídrico sobre o crescimento, os rendimentos e qualidade de frutos. A irrigação é útil na busca de um crescimento e rendimento máximos numa ampla gama de condições de cultivo em todo o mundo. Em geral, árvores maduras requerem de 1000 a 1563 mm (Van Bavel et al., 1967) de água ao ano para compensar as perdas referentes à evaporação e transpiração ( $E T)$, ainda que perdas devido a escorrimento superficial e percolação também sejam significativas. A ET das plantas cítricas não é superior a $80 \%$ da ET potencial. Smajstrla \& Koo (1984), não 
encontraram diferenças entre os rendimentos de citros "Valência" com reposição de 100, 50 e $25 \%$ da ET potencial.

Segundo Ortolani et al. (1991), a maior parte das regiões citrícolas do mundo dispõe de chuvas anuais entre 1000 e 2000 mm, com sazonalidade, apresentando uma estação seca. De modo geral, esses totais são menos importantes que a sua distribuição, pois a disponibilidade de água depende do balanço entre a evapotranspiração da cultura e a precipitação pluvial no decorrer do ciclo fenológico dos citros, correspondentes às fases de indução floral ou pré-florescimento, estabelecimento, crescimento e maturação do fruto e crescimento vegetativo.

Muitos são os fatores que interferem nas necessidades hídricas dos citros (espaçamento, idade, vento, umidade do ar, etc), entretanto, pode-se afirmar que esta necessidade varia entre 600 e $1300 \mathrm{~mm}$ anuais. Os estresses hídricos são extremamente prejudiciais à cultura, principalmente se durante o florescimento e o pegamento dos frutos, e também durante toda a fase de desenvolvimento do fruto (Bem Mechlia \& Carrol, 1989).

Em condições de cultivo normais, a formação de folhas novas excede a queda de folhas velhas, de modo que as plantas adultas estão sempre verdes. A principal fase de queda de folhas e de crescimento de folhas novas e frutos ocorre durante o florescimento da primavera, época de grande necessidade hídrica para os citros. Como toda planta perene, a resposta dos citros à água num determinado estádio de crescimento depende da sua disponibilidade hídrica anterior (Doorenbos \& Kassan, 1979). Segundo Angelocci (2000), o repouso durante o ano é importante para o período de floração, pois é nele que ocorre a indução da gemas florais. O repouso pode ser induzido por baixas temperaturas $\left(10^{\circ} \mathrm{C}\right)$ em climas subtropicais, mas em climas tropicais o frio pode ser substituído por período de deficiência hídrica, por exemplo, durante dois meses. A relação entre o grau de floração e de crescimento vegetativo posterior depende da intensidade da deficiência no período de repouso: deficiência acentuada pode induzir depois a formação 
excessiva de flores, com efeito no crescimento vegetativo e no rendimento, inclusive em produções subsequentes. A floração ocorre com a eliminação da deficiência. No Estado de São Paulo existe uma predominância de climas tropicais de altitude ou mesotérmicos úmidos. Estes são caracterizados por duas estações distintas: uma de verão úmido e quente, de outubro a março, com meses de transição (abril/maio) e outra de inverno seco (junho/agosto). Setembro é um mês de transição, com características bem variáveis (Ortolani et al., 1991).

A maioria dos mapas de zoneamento fornecem apenas uma visão macroclimática geral e às vezes conflitante pelos métodos usados e de classes de adaptação estabelecidas. O comportamento e capacidade de produção de citros no Estado de São Paulo têm demonstrado que a influência dos tipos de solos, das combinações cavalo-copa e do sistema radicular são fatores preponderantes na conceituação de classes agroclimáticas de aptidão. Além desses fatores, outras variáveis como radiação solar, amplitude diária e estacional da temperatura do ar, umidade do ar e duração do molhamento foliar, velocidade e direção dos ventos devem ser consideradas em estudos de classes de aptidão agroclimáticas. Essas associações mais complexas devem levar em consideração os momentos fenológicos mais importantes das plantas cítricas, para possibilitar o desenvolvimento de modelos que simulem as etapas de pré-florescimento, estabelecimento do fruto, crescimento vegetativo, crescimento do fruto e produção final (Ortolani et al., 1991).

\subsection{Estimativa do consumo de água do solo para citros}

O conhecimento da demanda hídrica por parte de uma cultura é muito importante para a elaboração de um projeto de irrigação. Para isso existe uma extensa metodologia que pode ser utilizada na determinação da ET de referência ou na sua estimativa através da evapotranspiração potencial $\left(E T_{0}\right)$, sendo no entanto necessário o uso de um coeficiente adequado, o coeficiente de cultura, kc (Doorembos \& Pruit, 1977). 
A evapotranspiração de uma cultura como dos citros, do tipo arbórea, geralmente é um parâmetro difícil de ser medido (Koo, 1958) sendo comum a utilização de valores estimados. As estimativas obtidas geralmente de modelos agrometeorológicos mais ou menos complexos como por exemplo os de Penman (1948) ou de Thornthwaite \& Math Penman (1948) ou de Thornthwaite \& Mather (1955) ou através de aparelhos mais simples como o tanque Classe A. Esses resultados precisam ser ajustados pelo coeficiente de cultura $(\mathrm{kc})$.

Para Angelocci (2000), uma opção prática para a determinação da exigência hídrica de frutíferas é o uso de coeficientes de cultura $(K c)$, que relacionam a evapotranspiração máxima da cultura ETm (isto é sem deficiência hídrica que comprometa o crescimento), com a evapotranspiração de referência ou potencial ETo (de um gramado extenso, em crescimento ativo e, também, sem deficiência hídrica), pela expressão:

$$
\mathrm{ETm}=\mathrm{Kc} . \mathrm{ETo}
$$

O valor de coeficiente de cultura depende, portanto, das condições de crescimento das árvores (relacionando-se então com a própria idade das plantas no caso de frutíferas que vegetam o ano todo, como os citros da idade), da geometria de plantio, bem como da existência ou não de vegetação intercalar. Se a superfície do solo estiver muito úmida, a evaporação pode representar uma boa fração da ETm, principalmente nos estágios iniciais de crescimento da cultura.

A FAO organizou, através de especialistas, documentos com valores indicativos de $\mathrm{Kc}$ para diversos estágios de culturas, incluindo-se várias frutíferas arbóreas. Uma revisão recente desses valores encontra-se no texto de Allen et al. (1997). Evidentemente, tais valores são aproximados, sendo uma recomendação da $\mathrm{FAO}$ que a pesquisa se preocupe em ajustá-los como valores regionalizados, de acordo com variedades e condições de clima. 
As referências na literatura sobre o coeficiente kc para os citros são escassas, nas publicações internacionais e principalmente nas publicações nacionais. Duas importantes publicações da FAO, Doorembos \& Kassam (1979) e Doorembos \& Pruit (1984) fizeram uma síntese para as difirentes condições de cultivo e estágio de crescimento da cultura, ao longo do ano:

Jan Fev Mar Abr Mai Jun Jul Ago Set Out Nov Dez

$\begin{array}{llllllllllll}0,90 & 0,90 & 0,85 & 0,85 & 0,85 & 0,85 & 0,85 & 0,85 & 0,85 & 0,85 & 0,85 & 0,85\end{array}$

Segundo Ribeiro (1993), para as condições de Limeira em solo litólico de textura variada, o limão tahiti sobre o porta-enxerto limão Cravo com 3 anos e meio de idade e formado sem irrigação, o oceficiente de cultura kc, variou, em média, de 0,61 a 0,90 durante o ano. Em seu trabalho, as determinações de umidade do solo tinham a finalidade de controle e manejo da microaspersão, portanto, o coeficiente de cultura obtido foi denominado kc operacional.

No Arizona, Hilgeman \& Van Horn (1954) determinaram a razão entre a evapotranspiração (ET) e a evaporação (EV) do tanque Classe A. Esses resultados variaram de $0,45 \mathrm{em}$ janeiro à $0,58 \mathrm{em}$ julho. No sul da Califórnia durante o verão, Reeve \& Furn (1941) obtiveram razões entre ET/EV mais baixas, de 0,25 para 0,30, sendo que as medidas em tanque evaporimétrico, eram feitas em tanque raso de fundo preto. Kalma (1972) acompanhando balanço hídrico e variações da umidade do solo num pomar de laranjas em Israel, plantado com espaçamento $4 \times 4$ m encontrou valores médios de ET/EV de 0,54 . As taxas de ET variaram de $1 \mathrm{~mm}$ no inverno a $4,4 \mathrm{~mm}$ no verão. No Arizona, Van Bavel et al. (1966) estimaram ET/EV de 0,66 para um pomar maduro. Taxas diárias de ET, no Arizona, variaram de 0,9 mm no inverno a 5,3 mm no verão.

Rogers et al. (1983), Koo \& Hurner (1969) and Hoffman et al (1982), os dois primeiros para as condições da Florida, e o último, para as condições do Arizona, são trabalhos definitivos a respeito da ET para essa cultura, cujos resultados são até hoje referenciados. Rogers et al (1983) encontraram valores 
de ET anual medida da ordem de 820 a $1280 \mathrm{~mm}$ (média de $1210 \mathrm{~mm}$ ), Boman (1994) monitorando dois anos de ET (1989 e 1990) também na Flórida encontrou valores de 1272 e 931 . Koo \& Hurner (1969), utilizando dados de Koo (1963), relatam valores de ET de $1170 \mathrm{~mm}$, para pomares não cultivados na entrelinha, e Hoffman et al.(1982) encontraram valores de $1470 \mathrm{~mm}$, para plantas maduras de citros. As sugestões de kc feitas pelo trabalho de Rogers et al (1983) são superiores aquelas sugeridas por Doorembos \& Pruitt (1975), com kcs da ordem de 0,95 e 1,00. A metodologia utilizada por estes pesquisadores foi com o uso de lisímetros.

Fares \& Alva (1999), trabalhando com plantas jovens de citros para as condições da Florida, encontraram ET da ordem de 32 a $68 \%$ da $\mathrm{ET}_{0}$, valores já bem abaixo dos encontrados por Rogers et al.(1983), para as mesmas condições. Castel (1997) monitorando plantas jovens de citros em Valência, na Espanha, sugerem valores de kc 20\% menores que os sugeridos por Doorembos \& Pruitt (1975) para plantas de mesmo tamanho.

Conforme observado, os resultados de consumo de água e kc são muito variáveis. A idade das plantas, as condições de cultivo, a combinação copa porta-enxerto, solo e clima, são elementos que dificultam a obtenção de valores práticos para uso extensivo na orientação da irrigação. A quantidade de água necessária à cultura, e que se pode aplicar na forma de irrigação, pode ser calculada estimando-se a evapotranspiração potencial e multiplicando-se por um fator $(\mathrm{kc})$, que representaria a demanda ideal, favorecendo a obtenção de elevadas produções. Na estimativa da evapotranspiração para projetos de irrigação, segundo Pires (1992) a utilização de valores médios mensais requerem algumas avaliações. A autora cita Arruda \& Barroso (1984). Em condições de clima subtropical, o valor médio mensal possivelmente poderia subestimar a real demanda por incluir em seu cálculo as baixas evaporações de dias chuvosos e nublados. 


\subsection{Solos e sistema radicular de citros}

O solo fundiona como suporte onde as plantas apóiam as suas raízes, fornecendo água para a sua fotossíntese, elementos minerais para a sua nutrição e oxigênio para o seu metabolismo.

Segundo Doorenbos \& Kassan (1979) a maioria das espécies de citros desenvolvem um só raiz pivotante e as raízes laterais formam uma manta horizontal de raízes alimentícias com pelo radiculares fracamente desenvolvidos.

A importância do sistema radicular sobre o desenvolvimento, crescimento e frutificação das espécies vegetais é um fato incontestável por ser este órgão a sede de alguns dos principais processos metabólicos que atuam no funcionamento geral da planta. O sistema radicular das plantas cítricas, da mesma forma que a maioria das árvores, é relativamente intolerante às condições de má drenagem (Reuther, 1973).

A presença de água livre na zona de enraizamento resulta em aeração deficiente e em injúrias para as plantas (Camargo, 1987). Segundo Jones \& Embleton (1973), raramente se encontram bons pomares cítricos em solos que não apresentam boa drenagem até, pelo menos, $100 \mathrm{~cm}$ de profundidade. Duas causas podem ser responsáveis pela limitação do desenvolvimento do sistema radicular devido ao excesso de água no solo: a) a presença de lençol freático elevado; b) a presença de camadas compactadas pouco profundas no perfil, ambas, diminuindo consideravelmente o fluxo vertical descendente da água, causando estagnação em períodos de muita precipitação pluvial (Oliveira \& Van Berg, 1985).

De acordo com Montenegro (1980), nos solos argilosos o sistema radicular dos citros encontra menor facilidade para penetrar, sendo, por isso, menos abundante, originando plantas de menor porte. Em solos arenosos, por serem normalmente porosos e arejados, produzem plantas com maior sistema radicular e maior volume de copa. 
Rodrigues (1979) relata que os pomares de citros em São Paulo estão situados praticamente em cinco tipos principais de solos, a saber: Podzólico variação Marília, Podzólico variação Lins, Latossolo Vermelho-Escuro fase arenosa, Latossolo Vermelho-Escuro Orto e Latossolo Vermelho-Amarelo fase arenosa. O mesmo autor ressalta que as plantas cítricas se adaptam muito bem a esses tipos de solos, mediante suprimento de suas necessidades nutricionais com adubos químicos e/ou orgânicos. Segundo Nel (1984), as propriedades físicas desses solos influenciam os processos de crescimento da planta de duas formas: elas determinam o grau de liberação de água para absorção pelas raízes e influenciam o caminho e a taxa pela qual as raízes podem penetrar no solo na procura de água e nutrientes.

Pace (1979) estudou o sistema radicular de laranjeira "Natal" com 5 anos de idade, sobre três porta-enxertos de citros, em solo Podzólico Vermelho (Argissolo Vermelho), no Estado do Rio de Janeiro, pelo método da trincheira. Encontrou maior percentual de radicelas nos primeiros $20 \mathrm{~cm}$ de profundidade do solo, na área correspondente ao raio da projeção da copa. Constatou, também, acentuada diminuição de radicelas abaixo de $20 \mathrm{~cm}$, sendo muito pequena a quantidade abaixo de $80 \mathrm{~cm}$.

Ford (1954), estudando a influência da idade das plantas, encontrou que com o aumento da idade variavam as proporções das raízes nas diversas profundidades avaliadas. De um modo geral, as raízes absorventes superficiais estavam um pouco mais profundas nas plantas mais velhas. Em solo muito arenoso como estudado por Ford, laranjeiras enxertadas sobre limão "Rugoso" com 25 anos de idade, apresentaram maior quantidade de radicelas na camada de 75 a $150 \mathrm{~cm}$ de profundidade do que na camada de 0 a $25 \mathrm{~cm}$.

Cahonn \& Stolzy (1960), na Califórnia, estudando a distribuição das raízes em pomar de citros irrigado, encontraram estreita correlação com a umidade do solo. Nos três tipos de solos estudados encontraram sempre a maior quantidade de raízes e a maior umidade do solo nas camadas superficiais, acima de $60 \mathrm{~cm}$. 
Montenegro (1960), estudando a distribuição do sistema radicular de laranjeiras "Hamlin", "Baianinha" e "Pêra", emxertadas sobre diversos portaenxertos, constatou que a distribuição horizontal das raízes foi de 75 a $94 \%$ num raio de 2 metros. Quanto a profundidade, constatou que, em árvores de 10 anos, $90 \%$ das raízes estão na camada de solos que vai da superfície 'a profundidade de $60 \mathrm{~cm}$, e que, para árvores com 23 anos, $90 \%$ das raízes estão localizadas na camada que vai da superfície à $90 \mathrm{~cm}$.

Moreira (1983), estudando laranjeiras da cultivar "Pêra" sobre portaenxerto limão Cravo, constatou que as radicelas localizavam-se superficialmente, com $50 \%$ delas nos primeiros $15 \mathrm{~cm}$ do solo e mais $10 \%$ até a profundidade de $30 \mathrm{~cm}$. Horizontalmente, as radicelas ocorriam a distância de $420 \mathrm{~cm}$ do tronco, com a maior concentração entre as distâncias de 140 e 350 $\mathrm{cm}$.

Nooling (1992) trabalhando em solos arenosos bem drenados na Flórida com laranja Valência, encontrou $99 \%$ do volume total de raízes no primeiro metro de profundidade, sendo que $77 \%$ encontrava-se nos primeiros $0,60 \mathrm{~m}$.

Apesar da relativa semelhança existente entre o sistema radicular das espécies frutíferas e arbóreas, a distribuição horizontal e vertical das raízes depende de vários fatores, a saber: idade da planta, variedade, origem da raiz (semente ou porta-enxerto), tipo de porta-enxerto, classe de solo e manejo adotado na condução do pomar. A maioria das raízes distribui-se horizontalmente em torno de $2 \mathrm{~m}$ e a maior concentração de radicelas situa-se nos primeiros $0,5 \mathrm{~m}$ de profundidade (Kolesnikov, 1971). Segundo Jones \& Embleton (1973) para as plantas cítricas, em solos bem drenados, tem sido observado o crescimento de raízes a profundidades de 1,2 e 1,5 m, com a maior concentração entre 0,6 e 0,9 m.

Paiva et al. (1998), avaliando a disponibilidade de água em solos do Tabuleiro Costeiro, verificaram que as laranjeiras revelaram maior desenvolvimento vegetativo no Podzólico Acinzentado em comparação com o 
Latossolo Amarelo e Podzólico Amarelo, apresentando conteúdo de água disponível superior até a profundidade de $1,50 \mathrm{~m}$. Os autores relataram que tais resultados, possivelmente são decorridos da posição dos solos na paisagem, aliada à textura, que controlaram o conteúdo de água disponível. Cintra et al. (2000), na mesma região fisiográfica, analisando o balanço hídrico de citros em solos coesos, verificaram maior demanda hídrica nos meses de outubro e novembro, além da fase de maturação dos frutos (final do período seco). No mesmo trabalho, os autores verificaram pouca adaptação nestes solos da Tangerina Cleópatra, com base na taxa de evapotranspiração em período de grande demanda hídrica.

\subsection{Extração de água por raízes de culturas}

O conhecimento detalhado da dinâmica da água durante $\mathrm{O}$ desenvolvimento de uma cultura fornece elementos essenciais ao estabelecimento ou aprimoramento de práticas de manejo agrícola que visam a otimização da produtividade. O estudo da dinâmica da água em condições de campo, dando ênfase a fluxos de água na zona radicular da cultura, são escassos e muitas vezes incompletos (Reichardt et al., 1979). Black et al. (1970), Cruciani (1972) e Pereira et al. (1974) são exemplos de trabalhos nos quais é dada ênfase a fluxos de drenagem abaixo da zona radicular. Outros trabalhos utilizando a mesma metodologia não são do nosso conhecimento até o momento, dadas às dificuldades apresentadas pelo método no que diz respeito ao conhecimento detalhado das propriedades hídricas do solo.

Segundo Nye \& Tinker (1977), existe uma tendência dos sistemas radiculares mudarem de perfil durante a estação de crescimento. Para culturas anuais isto é, em parte, o resultado da extensão normal das raízes, mas para culturas anuais e perenes pode acontecer quando as partes superiores do solo secam, e as raízes na superfície podem ficar inativas, como em cultivo de centeio (Garwood \& Williams, 1967). Em áreas com chuva limitada, os sistemas 
radiculares podem ser limitados a profundidade de umedecimento durante a estação chuvosa.

Gardner (1964) relacionou a distribuição radicular de sorgo medida com a estimada por modelo matemático, neste trabalho o autor já comentava a dificuldade de obter-se uma boa estimativa da distribuição radicular a partir de amostras de solo.

Rose e Stern (1967), fazem uma análise completa da extração de água do solo, apresentando pormenores da dinâmica da extração de água pelas raízes de uma cultura. A aplicação do método proposto por estes autores é difícil devido à necessidade de uma caracterização físico-hídrica detalhada do perfil do solo. Reichardt et al. (1979) utilizou-se desta metodologia, concluindo que, apesar das dificuldades já citadas, o estabelecimento de um balanço hídrico completo pode fornecer informações úteis para o manejo correto de diferentes culturas em diferentes solos.

\subsection{Estatística descritiva e análise exploratória de dados}

A estatística não espacial, freqüentemente referida como estatística clássica, também é usada para examinar aspectos de variabilidade espacial dos parâmetros físicos do solo. Neste caso a amostragem é feita de forma inteiramente casualizada e sem considerar a posição relativa de cada variável no espaço. Também se assume que as amostras são completamente independentes entre si. Estes métodos estatísticos foram desenvolvidos a partir do ano de 1919, quando Ronald A. Fischer assumiu a direção do Departamento de Estatística da Estação Experimental de Rothampstead em Londres e passou a buscar métodos matemáticos que lhe possibilitasse obter conclusões sobre vários fenômenos experimentais. A base teórica e detalhamento dos métodos estatísticos clássicos estão amplamente descritos em (Spiegel, 1968; Gomes 1987a; Gomes, 1987b; Banzato \& Kronka, 1995, Levine et al., 1998). Outros autores discutem diretamente a aplicação destes conhecimentos ao estudo da 
variabilidade dos solos (Warrick \& Nielsen, 1980; Reichardt et al., 1986; Souza, 1992; Miyazaki, 1993; Mulla \& McBratney, 2000).

Os parâmetros estatísticos considerados pela estatística clássica são a média, a moda, a mediana, o desvio padrão da média, a variância, a distribuição da freqüência dos dados, o coeficiente de variação, a assimetria, a curtose e os intervalos de confiança para as estimativas dos dados. A média e seu correspondente desvio padrão são duas características chaves para a análise inicial da variabilidade de uma população.

Segundo Libardi et al. (1996), o desvio padrão tem a vantagem de apresentar a variabilidade dos dados na unidade de medida original, sendo, desta forma, recomendável como estatística de avaliação da variabilidade. Porém a utilização do desvio padrão para comparação de duas variáveis diferentes é inadequada, visto que as unidades de medida também são diferentes. Neste caso torna-se necessário uma medida relativa da variabilidade, tal qual o coeficiente de variação. Este coeficiente de variação é um número que representa o desvio padrão em percentagem da média.

O CV é um número abstrato e relativo, que indica a precisão dos dados e possibilita a comparação racional entre valores diferentes. Propriedades do solo com CV elevado são mais variáveis que aquelas com baixo valor de CV. Neste caso, existe até proposições de uma classificação para identificar a extensão da variabilidade das propriedades do solo com base no seu coeficiente de variação.

Warrick \& Nielsen (1980) classificaram a variabilidade das propriedades do solo, expressa pelo coeficiente de variação, em três níveis: Baixa variação ( $C V<12 \%)$, média $(12 \%<C V<80 \%)$ e alta $(C V>80 \%)$. Por outro lado, Mulla \& McBratney (2000) citam outro esquema de classificação bem mais rigoroso, no qual valores de $0-15 \%, 16-35 \%$ e $>36 \%$, para o coeficiente de variação, indicam pequena, média e alta variabilidade, respectivamente. 
Informações complementares aos momentos estatísticos já descritos podem ser obtidas pela caracterização da freqüência de distribuição dos parâmetros medidos, contribuindo para definir de maneira mais completa a sua variabilidade.

A dispersão de uma freqüência de distribuição normal em torno da média é uma importante medida da variabilidade da população amostrada. A curva de freqüência de distribuição para uma população com alta variabilidade apresenta-se relativamente larga e ampla, ao contrário, se a população varia pouco, a curva tem aspecto estreito e muitos dos seus valores estarão bem próximos da média e mediana.

Segundo Reichardt et al. (1986) foram Nielsen et al. (1973) provavelmente os primeiros autores a verificarem que as propriedades do solo obedecem a diferentes padrões de distribuição. De acordo com os autores muitas propriedades do solo, como teores de areia e argila, apresentam uma distribuição normal, enquanto outras, como a condutividade hidráulica, seguem distribuição assimétrica, geralmente log-normal. Estes padrões de distribuição também foram encontrados por vários pesquisadores; areia e argila (Vieira, 1997), condutividade hidráulica (Libardi et al., 1980; Banton, 1993; Logsdon \& Jaynes, 1996).

Existem diversos métodos para identificar qual o tipo de distribuição de um conjunto de dados. Jones (1969) propõe a utilização de tabelas relacionando os valores de assimetria e curtose para testar a normalidade de um conjunto de dados com base na teoria estatística dos testes de hipótese. Moraes (1991) e Beiguelman (1994) detalham o método dos momentos estatísticos, informando que é um dos mais utilizados para este propósito e Libardi et al., (1996) demonstram a verificações da normalidade para os métodos do gráfico de Henry, "Box-plot" e ramos e folhas.

As distribuições de freqüência de um conjunto de dados não diferem apenas quanto ao valor médio (ou às medidas de tendência central, de um modo geral) e à variabilidade, mas também quanto a sua forma. Com relação à 
forma, as características mais importantes são o grau de deformação da distribuição, ou assimetria e o grau de achatamento ou afilamento da curva de freqüências ou histograma. As medidas de assimetria nos indicam a quão deformada é uma distribuição. As medidas de curtose (excesso) nos dão idéia de quanto a curva de freqüências da distribuição é mais afilada ou mais achatada do que uma curva padrão, denominada curva normal. 


\section{MATERIAL E MÉTODOS}

\subsection{Descrição geral da área}

\subsubsection{Localização}

O estudo foi realizado em campo experimental de citros (Apêndice1), Departamento de Produção Vegetal, Esalq/USP, município de Piracicaba (SP). Esta área localiza-se a $22^{\circ} 42^{\prime} 43,3^{\prime \prime}$ de latitude sul e $47^{\circ} 37^{\prime} 10,4^{\prime \prime}$ de longitude oeste, a uma altitude de $580 \mathrm{~m}$. A área escolhida constitui-se de duas linhas de cultivo com extensão de $100 \mathrm{~m}$ cada uma. As duas linhas são cultivadas com pomares de citros, variedade Valência, sobre porta-enxerto Cleópatra, com 11 anos de idade. A Figura 1 mostra um esquema da localização da área experimental, bem como da disposição espacial das avaliações que foram efetuadas.

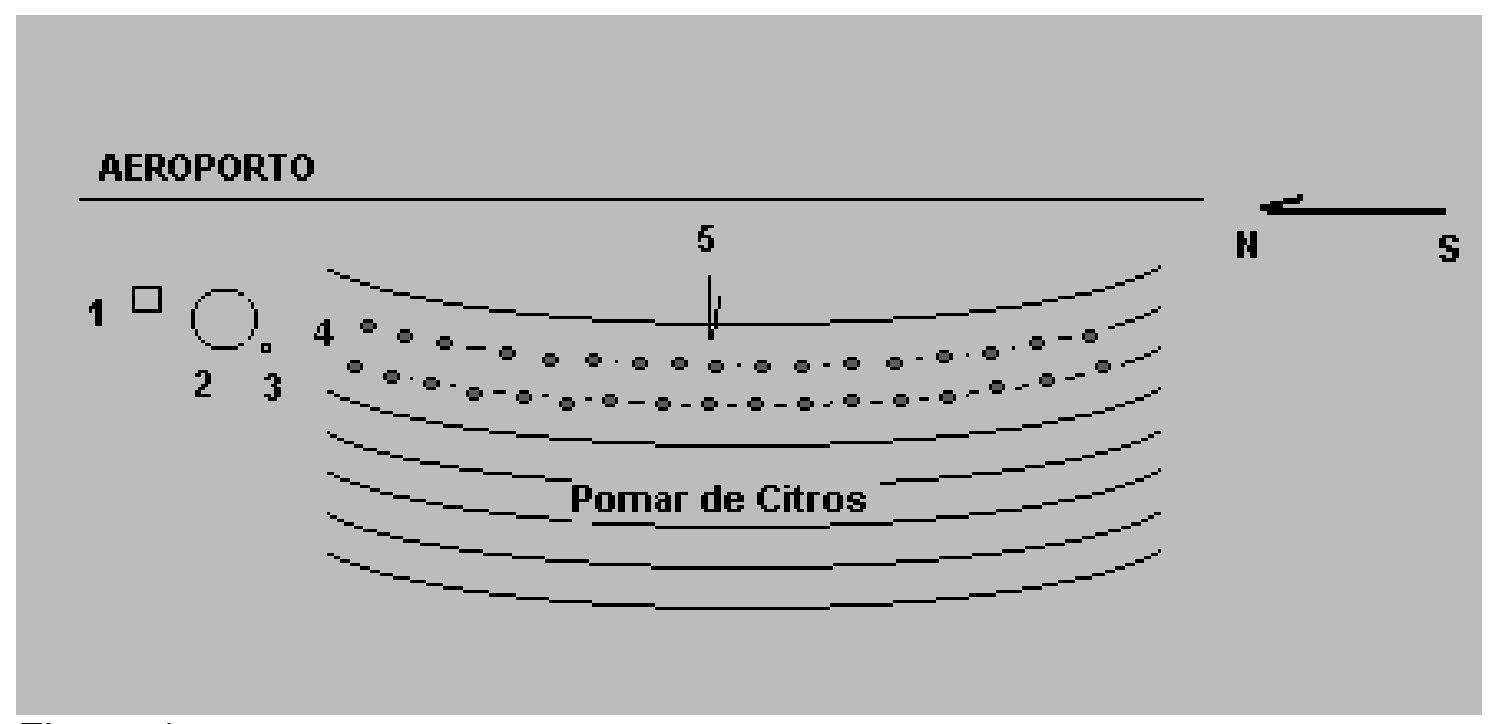

Figura 1 - Esquema da localização da área experimental: (1) trincheira para a coleta de amostras deformadas e descrição morfológica do perfil do solo; (2) experimento de condutividade hidráulica; (3) pluviógrafo; (4) transeções, com 20 plantas por linha de 100 metros; (5) planta para a avaliação de extração de água. 


\subsubsection{Clima}

No município de Piracicaba o clima é do tipo Cwa, segundo a classificação de Köppen, denominado "tropical de altitude". É um clima mesotérmico de inverno seco, em que a temperatura média do mês mais frio é inferior a $18^{\circ} \mathrm{C}$ e a do mês mais quente ultrapassa $22^{\circ} \mathrm{C}$. As médias anuais de temperatura, precipitação e umidade relativa são de $21,1^{\circ} \mathrm{C}, 1.257 \mathrm{~mm}$ e $74 \%$, respectivamente. A estação seca ocorre entre os meses de abril e setembro, sendo julho o mês mais seco. O mês mais chuvoso oscila entre janeiro e fevereiro e o total das chuvas do mês mais seco não ultrapassa $30 \mathrm{~mm}$ (Serviço Nacional de Pesquisas Agronômicas, 1960).

\subsubsection{Solo}

A caracterização morfológica do solo foi realizada a partir de trincheira aberta na área (Figura 1), de onde foram retiradas amostras para as seguintes determinações: análise granulométrica (Apêndice 2), análise química e a determinação de óxidos por ataque sulfúrico (Apêndice 3 ), segundo a metodologia utilizada no laboratório do Departamento de Solos e Nutrição de Plantas da ESALQ/USP(Gee \& Bauder,1986). O solo foi classificado como Latossolo Vermelho-Amarelo Distrófico argissólico (Apêndice 2).

\subsubsection{Descrição da cultivar}

Valência (Citrus sinensis L. Osbeck)

Cultivar de origem supostamente espanhola, entretanto, sem confirmação. Apresenta árvores de porte médio a grande, com folhagem abundante. Sua produção pode atingir cerca de $200 \mathrm{~kg}$ de frutos por planta. Os frutos apresentam cerca de $50 \%$ do seu peso em suco, e podem ser destinados tanto para o consumo in natura, como para as industrias de suco concentrado. No Estado de São Paulo, estima-se que creca de $9 \%$ do total de árvores plantas sejam de 'Valência'. É cultivar de maturação tardia, que se estende de agosto a setembro. 
O porta-enxerto é o limão 'Cravo' (Citrus reticulata var. austera). Segundo Figueiredo et al.(1981), este porta-enxerto está presente na maior parte dos pomares do Estado de São Paulo, fato tido como extremamente arriscado, sendo necessário a introdução de novos porta-enxertos o mais rápido possível.

\subsection{Caracterização hidráulica do solo}

\subsubsection{Curvas de Retenção}

Numa trincheira de $3 \times 2 \times 1,5 \mathrm{~m}$ (Figura 1), distante cerca de $10 \mathrm{~m}$ da transeção, foram coletadas amostras com estrutura indeformada com o objetivo da elaboração das curvas de retenção. Esta amostragem foi feita com o aparelho de Uhland. Cada anel de coleta apresenta aproximadamente $0.05 \mathrm{~m}$ de altura e $0.048 \mathrm{~m}$ de diâmetro. Foram retiradas 10 amostras em cada profundidade, ou seja, nas profundidades de $0.1 ; 0.2 ; 0.3 ; 0.4 ; 0.5 ; 0.6 ; 0.7 ; 0.8$; $0.9 ; 1.0 ; 1.10$ e $1.20 \mathrm{~m}$. Estas amostras foram embrulhadas com papel alumínio e em seguida embainhadas com parafina derretida, para posteriormente serem armazenadas em refrigerador, mantendo assim o mínimo possível de alteração estrutural e perda de água. As amostras foram saturadas por um período de 24 horas, em um recipiente de plástico. Após a saturação, foi colocada uma amostra de cada profundidade em cada tensão. Como foi utilizada uma amostra para cada tensão, evitou-se a saturação de uma mesma amostra mais de uma vez, ou seja, cada ponto na curva foi determinado por uma amostra diferente, porém da mesma profundidade. No Apêndice 4 são apresentadas as curvas características da água do solo avaliado e na Tabela 1 , as respecitvas equações ajustadas. 
Tabela 1. Equações ajustadas referentes às curvas características da água no solo em cada profundidade amostrada.

\begin{tabular}{llr}
\hline Profundidades & Equações ajustadas & Densidade do solo \\
\hline 0,20 & $\theta=0,166+\frac{0,302-0,166}{\left[1+\left(1,002\left|\phi_{m}\right|\right)^{1,414}\right]^{1,267}}$ & 1,76 \\
0,40 & $\theta=0,179+\frac{0,343-0,179}{\left[1+\left(0,168\left|\phi_{m}\right|\right)^{1,489}\right]^{8,499}}$ & 1,66 \\
0,60 & $\theta=0,146+\frac{0,334-0,146}{\left[1+\left(2,415\left|\phi_{m}\right|\right)^{2,563}\right]^{p, 472}}$ & 1,55 \\
0,80 & $\theta=0,153+\frac{0,347-0,153}{\left[1+\left(2,098\left|\phi_{m}\right|\right)^{2,605}\right]^{0,740}}$ & 1,52 \\
1,00 & $\theta=0,156+\frac{0,371-0,156}{\left[1+\left(1,140\left|\phi_{m}\right|\right)^{1,, 266}\right]^{2,131}}$ & 1,53 \\
1,10 & $\theta=0,154+\frac{0,376-0,154}{\left[1+\left(0,099\left|\phi_{m}\right|\right)^{1,479}\right]^{4,115}}$ & 1,49 \\
\hline
\end{tabular}

As equações foram ajustadas pelo método de VanGenuchten (1980), com o auxílio do programa TableCurve 2D - Jandel Scientific - Copyright 19891994 - AISN Software.

\subsubsection{Condutividade hidráulica}

Optou-se por quantificar a condutividade hidráulica pelo método do perfil instantâbeo (Watson, 1966) conduzido no campo (Carvalho, 2003). Em área adjacente, com perfil de mesmas características, montou-se um experimento de avaliação de condutividade hidráulica pelo método do perfil instantâneo (Libardi, 2000) (Figura 1). Foi delimitada uma área de $3 \mathrm{~m}$ de diâmetro, com o uso de folha metálica (chapa galvanizada), até a profundidade de $1,0 \mathrm{~m}$. Neste local foram instalados tensiômetros nas profundidades de 0.1 , $0.2,0.3,0.4,0.5,0.6,0.7,0.8,0.9,1.0,1.1$, e $1.2 \mathrm{~m}$. Esta área foi saturada com 
auxílio de caminhão pipa e após sua cobertura com lona plástica( $\mathrm{p} /$ evitar evaporação, e com isso fluxo ascendente) foram avaliadas as tensões obtidas nos tensiômetros em intervalos de tempo pré-determinados. A função $K(\theta)$ foi obtida pela equação

$\left.K(\theta)\right|_{z}=\frac{-\int_{0}^{z} \frac{\partial \theta}{\partial t} d z}{\left.\frac{\partial \phi_{t}}{\partial z}\right|_{z}}$

na qual, o numerador é a variação da armazenagem de água com o tempo no intervalo de profundidade de 0 a $z$ e o denominador o gradiente de potencial $\operatorname{total}\left(\phi_{t}\right)$ na profundidade $z$.

$\mathrm{Na}$ Tabela 2 são apresentadas as equações da condutividade hidráulica $\mathrm{K}$ em função da umidade volumétrica $\theta$ por profundidade $\mathrm{e}$ respectivos coeficientes de correlação, obtidas no experimento.

Tabela 2. Equações da função $K(\theta)$ e coeficientes de correlação obtidos em experimento de condutividade hidráulica, pelo método do perfil instantâneo.

\begin{tabular}{lll}
\hline Profundidades & Equações & $\mathrm{r}^{2}$ \\
\hline 0,20 & $\ln K=86,488 \theta-24,504$ & 0,9905 \\
0,40 & $\ln K=70,484 \theta-17,857$ & 0,9834 \\
0,60 & $\ln K=72,944 \theta-18,398$ & 0,9890 \\
0,80 & $\ln K=67,654 \theta-16,058$ & 0,9834 \\
1,00 & $\ln K=58,872 \theta-13,779$ & 0,9823 \\
1,10 & $\ln K=46,298 \theta-11,550$ & 0,9956 \\
\hline
\end{tabular}

\subsection{A Transeção}

Conforme a Figura 1, o experimento de avaliação do consumo de água pela cultura de citros foi realizado em duas transeções com $100 \mathrm{~m}$ de comprimento, distantes 7,0 m uma da outra, contendo 20 plantas espaçadas de 4,0 m. As entrelinhas são cultivadas com grama-seda. 


\subsection{Tensiômetros e tubos de acesso para sonda de nêutrons}

Foram instalados 120 tensiômetros ao longo das duas transeções. Estes aparelhos foram colocados em 3 profundidades $(1,00 \mathrm{~m}, 1,10 \mathrm{~m}$ e 1,20 m) e numa distância de 2 metros do tronco (projeção da copa - Figura 2). As leituras de potencial mátrico foram realizadas diariamente; foram também instalados 40 tubos de alumínio com $1,5 \mathrm{~m}$ de comprimento e $0,045 \mathrm{~m}$ de diâmetro interno e parede de $1,5 \mathrm{~mm}$ de espessura. O tubo é selado na extremidade inferior e foi introduzido no solo até $1,1 \mathrm{~m}$ de profundidade (Figura 2). Para a instalação foi utilizado um trado do tipo holandês de diâmetro semelhante ao do tubo.

Estes tubos serviram de acesso à sonda de nêutrons para a quantificação da armazenagem de água até a profundidade de 1,1 m. A sonda de nêutrons utilizada foi uma 503 Hydroprobe da CPN Corporation, munida de uma fonte de ${ }^{241} \mathrm{Am} / \mathrm{Be}$ de intensidade radioativa de $1,85 \mathrm{GBq}$ e tempo de cada contagem de 30 s.

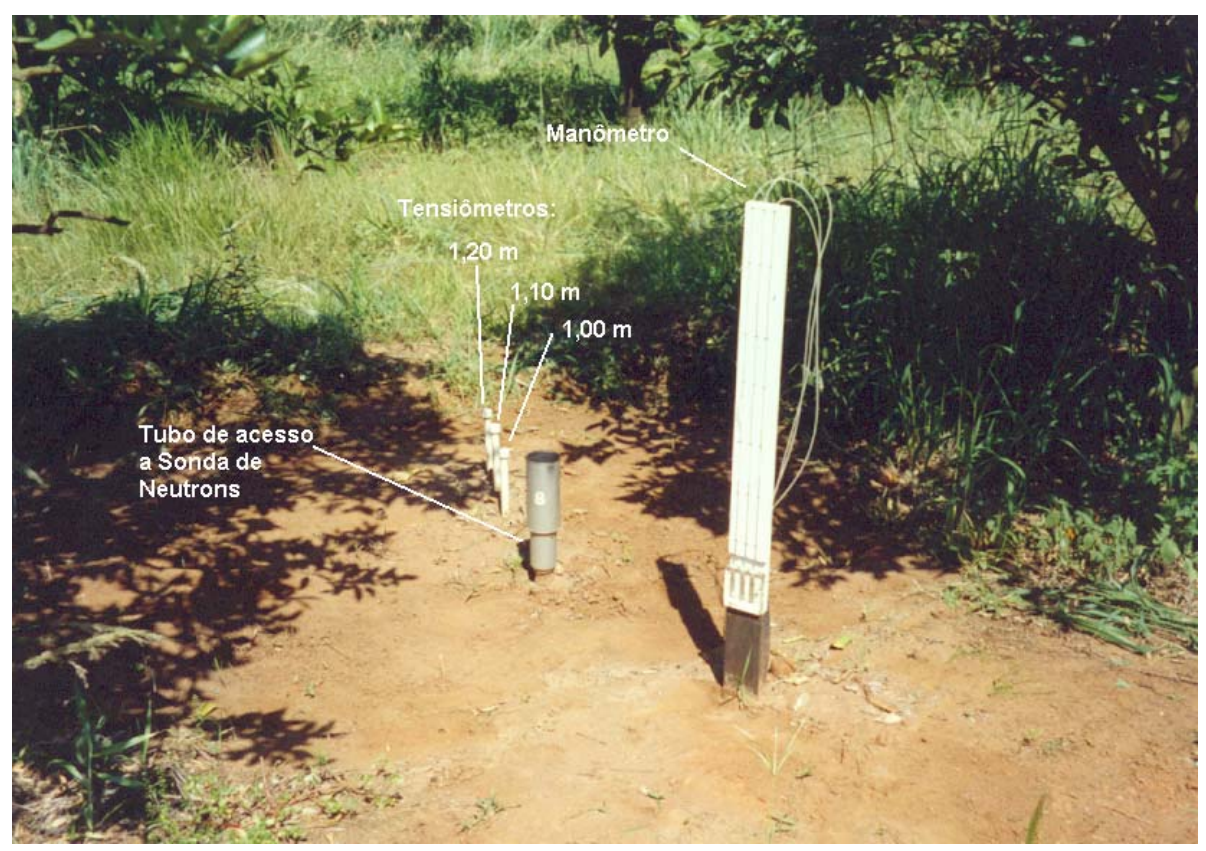

Figura 2 - Foto mostrando a disposição dos tensiômetros, tubo de acesso à sonda de nêutrons e suporte dos manômetros de mercúrio. 


\subsection{Avaliação da Evapotranspiração do Citros}

Esta determinação baseia-se na utilização da equação da conservação de massa, que mostra que a soma algébrica dos fluxos da água num determinado volume de solo é igual à variação da quantidade de água nele armazenada num dado intervalo de tempo (Rose \& Stern, 1967):

$$
\left.\int_{t i}^{t j} p+i \pm r-e t \pm q_{z}\right) d t=\int_{t i}^{t j} \int_{0}^{L}\left[\frac{\partial \theta}{\partial t}\right] d z d t
$$

Escrita de uma forma mais simplificada:

$P+I \pm D-E T \pm R= \pm \Delta h_{z}$

sendo: $\mathrm{P}$ - precipitação $(\mathrm{mm})$;

I - irrigação (mm);

$D$ - drenagem interna $(\mathrm{mm})$;

ET - evapotranspiração ( $\mathrm{mm})$;

$R$ - deflúvio superficial ( $\mathrm{mm}$ );

$\Delta \mathrm{h}_{\mathrm{z}}$ - variação de armazenagem (mm) (Figura 3). 


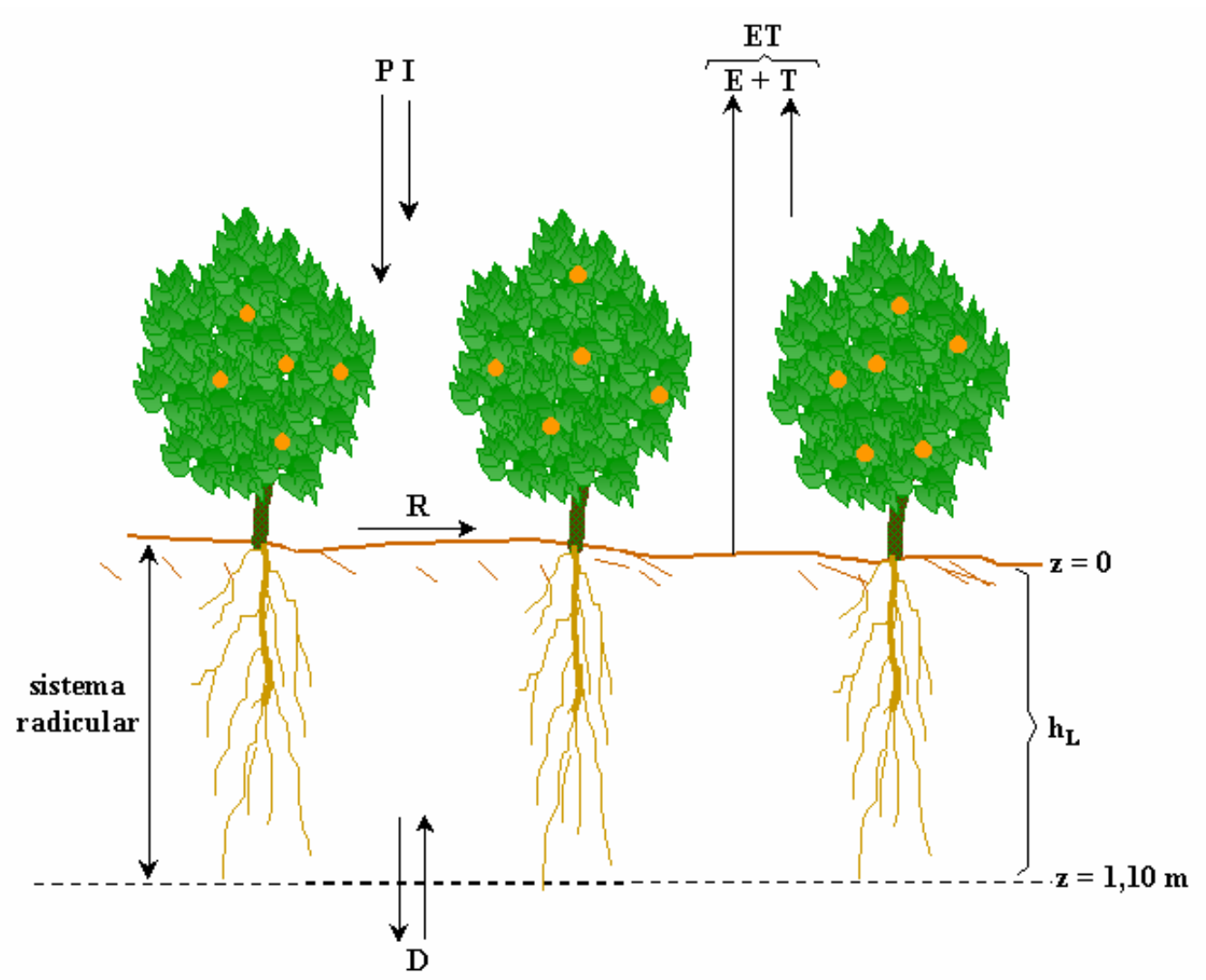

Figura 3 - llustração esquemática dos componentes do balanço hídrico em pomar de citros.

\subsubsection{Precipitação - $P$}

Calculada por:

$$
\int_{t i}^{t j} p d t=P
$$

sendo $\mathrm{p}$ a intensidade de precipitação $\left(\mathrm{mm} \mathrm{dia}^{-1}\right)$.

A contabilização da entrada de água por precipitação foi medida em equipamento agrometeorológico (Tipping Bucket Raingauge - Model TB3 Hydrological Services Pty Ltd.) instalado próximo a transeção avaliada.

\subsubsection{Irrigação - I}

Dada por: 


$$
\int_{t i}^{t j} i d t=I=0
$$

sendo i é a intensidade de irrigação $\left(\mathrm{mm} \mathrm{dia}^{-1}\right)$.

No caso presente, como a área não é irrigada, tal parâmetro foi desconsiderado na equação.

\subsubsection{Deflúvio superficial - $\mathbf{R}$}

Calculado por:

$$
\int_{t i}^{t j} r d t= \pm R=0
$$

sendo $\mathrm{r}$ a intensidade do deflúvio superficial $\left(\mathrm{mm} \mathrm{dia}^{-1}\right)$ que será positivo quando decorrente de contribuição à montante e negativo quando refletir perda de água por escorrimento superficial.

No presente trabalho este componente não foi considerado devido à área ser considerada plana, com variação de declividade em torno de $2 \%$.

\subsubsection{Drenagem interna ou ascensão capilar - D}

Calculada por:

$$
\int_{t i}^{t j} q_{z} d t= \pm D
$$

sendo $\mathrm{q}_{\mathrm{z}}$ a densidade de fluxo de água no solo $\left(\mathrm{mm} \mathrm{dia}^{-1}\right)$, que pode ser positiva se for decorrente de ascensão capilar e negativa se originada pela drenagem interna.

Este componente na profundidade e tempo considerados foi estimado pela equação de Darcy-Buckingham:

$$
q_{z}=-\left.K(\theta) \frac{\partial H}{\partial z}\right|_{L}
$$


na qual, a $K(\theta)$ foi obtida em experimento de condutividade pelo método do perfil instantâneo (Tabela 2) e o gradiente medido pela diferença entre os tensiômetros instalados nas profundidades 1,20 e 1,00 m, isto é,

$$
\frac{\partial H}{\partial z}=\frac{\phi_{t 1,2}-\phi_{t 1,0}}{0,2}
$$

sendo $\phi_{\mathrm{t} 1,0} \circ$ potencial total da água na profundidade $1,0 \mathrm{~m}, \phi_{\mathrm{t} 1,2} \circ$ potencial total da água na profundidade 1,2 m e 0,2 a distância, em metros, entre os dois tensiômetros.

\subsubsection{Evapotranspiração - ET}

Dada por:

$$
\int_{t i}^{t j} e t d t=-E T
$$

sendo et a intensidade da evapotranspiração $\left(\mathrm{mm} \mathrm{dia}^{-1}\right)$. Este componente foi determinado por diferença, por meio da equação simplificada para o balanço hídrico, visto que os outros componentes da equação foram determinados mediante a metodologia descrita anteriormente.

A avaliação da Evapotranspiração foi realizada durante um ciclo anual da cultura de citros. Este monitoramento foi realizado de 09/08/2001 à

\begin{tabular}{|c|c|c|c|}
\hline Período 1 & $9 / 08$ à $5 / 09 / 01$ & Período 8 - & $\begin{array}{l}23 / 01 \text { à } 23 / 02 / 02 \\
23 / 02 \text { à } 14 / 03 / 02\end{array}$ \\
\hline Período 2 & $5 / 09$ à $26 / 09 / 01$ & Período 9 - & $\begin{array}{l}23 / 02 \text { à } 14 / 03 / 02 \\
14 / 03 \text { à } 7 / 04 / 02\end{array}$ \\
\hline Período 3 & $\begin{array}{l}26 / 09 \text { à } 24 / 10 / 01 \\
24 / 10 \text { à } 14 / 11 / 01\end{array}$ & Período 10 - & $\begin{array}{l}14 / 03 \text { à } 7 / 04 / 02 \\
7 / 04 \text { à } 28 / 04 / 02\end{array}$ \\
\hline Período 5 & $14 / 11$ à $5 / 12 / 01$ & Período 12 - & $28 / 04$ à $16 / 05 / 02$ \\
\hline Período 6 & $5 / 12$ à 2/01/02 & odo 13 - & 5 à $7 / 06 / 02$ \\
\hline Períod & $2 / 01$ à $23 / 01 / 02$ & Perío & $21 / 08 / 02$ \\
\hline
\end{tabular}
21/08/2001, em 14 períodos, conforme segue:

Durante os mesmo períodos citados foi acompanhada a evaporação medida pelo Tanque Classe A (ECA) para a obtenção da relação entre a ETc e 
a ECA. O Tanque utilizado estava distante cerca de $500 \mathrm{~m}$ da área em estudo e possui as seguintes características:

-Tanque "Classe A" (ECA) - tanque cilíndrico construído em chapa galvanizada $\mathrm{n}^{\circ} 22$ (AWG), com 120,0 cm de diâmetro e $30 \mathrm{~cm}$ de profundidade, tendo como acessórios para as medidas, um poço tranqüilizador convencional nivelado por três parafusos e um micrômetro capaz de medir variações do nível da água de até $0,02 \mathrm{~mm}$; tal micrômetro fica assentado sobre o poço tranqüilizador por ocasião da tomada de leitura. Esse tanque está assentado sobre um estrado de madeira pintado de branco, com sua superfície distante $15,0 \mathrm{~cm}$ da superfície do solo. A quantidade de evaporação é medida diariamente nesse poço tranqüilizador com o parafuso micrométrico. Para evitar a ocorrência de derramamentos pela ação do vento, o nível da água deve ser mantido sempre entre 5 e $7,5 \mathrm{~cm}$ abaixo da borda do tanque.

\subsubsection{Variação de armazenagem $-\Delta h_{z}$}

Calculada por:

$$
\int_{0}^{L}\left[\int_{t i}^{t j}\left(\frac{\partial \theta}{\partial t}\right) d t\right] d z=\Delta h_{z}
$$

O componente variação de armazenagem foi determinado utilizandose os dados de umidade obtidos pelas leituras semanais com sonda de nêutrons até a profundidade de 1,10 m (Figura 2). Foi realizada uma calibração do aparelho nas condições e no solo avaliado (Gráfico - Apêndice 4), correlacionando 223 coletas de amostras. A equação da reta obtida pela calibração foi:

$$
U=-0,023+0,086 C R
$$

Optou-se pela calibração com a relação entre a contagem relativa e a umidade gravimétrica $U$ em função dos distúrbios advindos de uma coleta 
indeformada de solo. A transformação de $U$ para $\theta$ foi realizada após a obtenção da reta de calibração evitando com isso acumulação de erros. Esta transformação foi obtida pelo uso da equação:

$$
\theta=U \frac{\rho}{\rho_{a}},
$$

sendo $\rho$ a densidade do solo e $\rho_{a}$ a densidade da água. As densidades para cada profundidade foram obtidas pela média de 3 amostras indeformadas coletadas em área adjacente (Tabela 1).

\subsection{Eficiência de uso da água}

Com os dados de produtividade obtida na área de estudo foi determinada a eficiência de uso da água pela relação desta produtividade e a quantidade de água consumida pela cultura ao longo do ciclo, representada pela evapotranspiração estimada pela equação do balanço de água no solo.

$$
\text { E.U.A. }=\text { P.C. }{ }^{-1}
$$

sendo: E.U.A. - eficiência de uso da água $\left(\mathrm{kg} . \mathrm{m}^{-3}\right)$;

$\mathrm{P}$ - produção em kg.ha-1;

C - consumo de água em $\mathrm{m}^{3} \cdot \mathrm{ha}^{-1}$.

\subsection{Detalhamento de uma planta}

Em um ponto desta mesma transeção foram instalados tensiômetros em 5 profundidades $(0,20,0,40,0,60,0,80,1,00 \mathrm{~m})$ e a 5 distâncias do tronco $(0,40,0,80,1,20,1,60$ e 2,00 m). Dois destes conjuntos de 25 tensiômetros foram instalados, um em direção à linha, e outro, em direção à entrelinha de cultivo (Figura 4 e 5). Nesta planta foi avaliada a dinâmica da água sob a influência das raízes da planta de citros. 


\section{VISTA SUPERIOR}

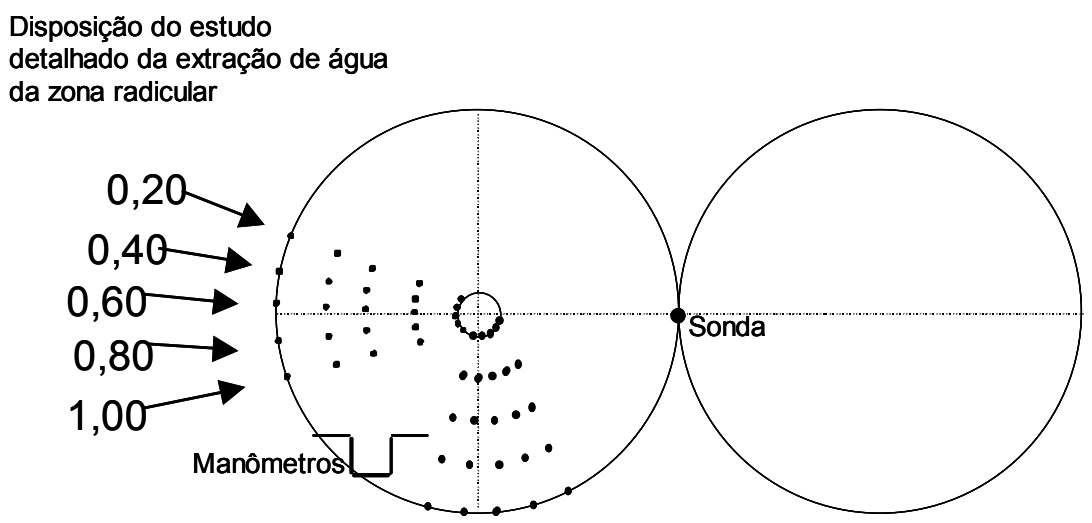

Distâncias da planta: 0,$4 ; 0,8 ; 1,2 ; 1,6 ; 2,0 \mathrm{~m}$

Profundidades por distâncias: 0,$2 ; 0,4 ; 0,6 ; 0,8 ; 1,0 \mathrm{~m}$.

Distância entre tensiômetros: 0,2 m.

Figura 4 - Vista superior da disposição dos tensiômetros no estudo detalhado da extração de água na zona radicular de citros.

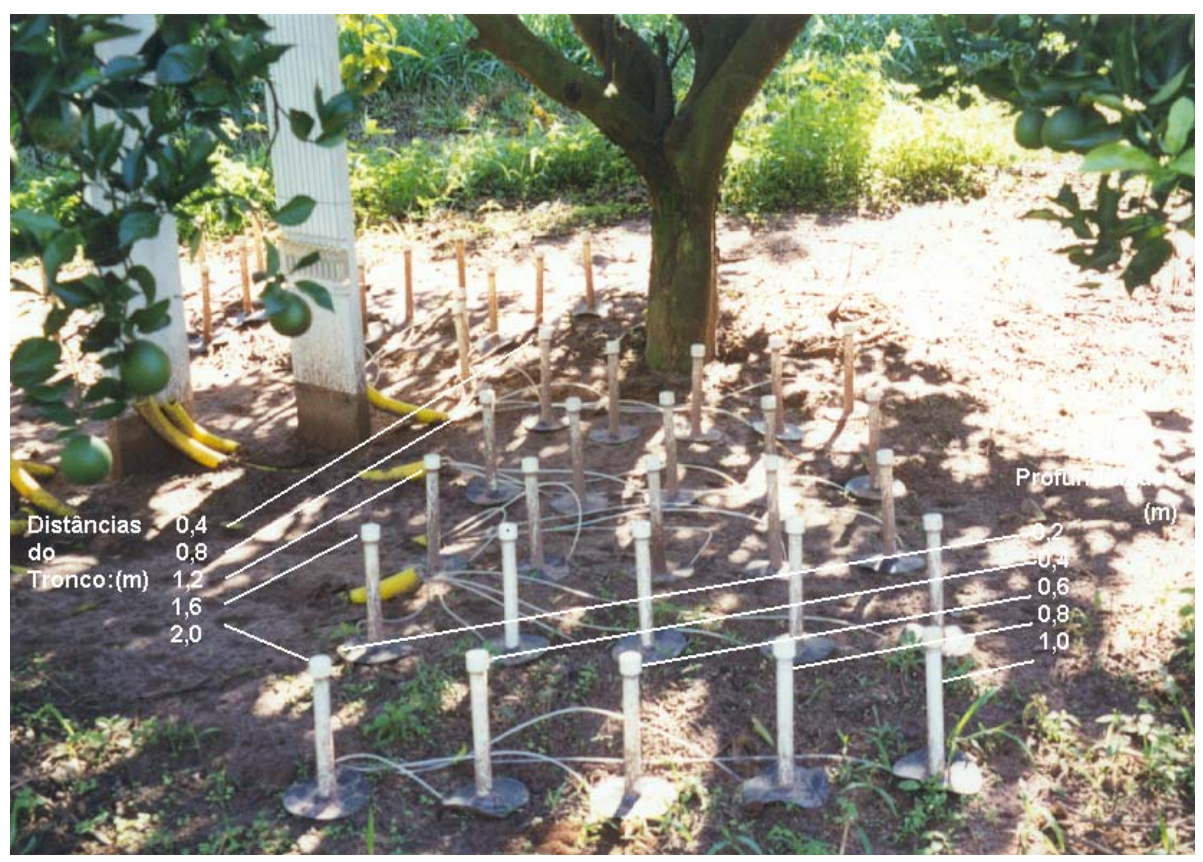

Figura 5 - Foto mostrando a disposição dos tensiômetros no estudo detalhado da extração de água na zona radicular de citros. As setas indicam as distâncias em relação ao tronco e as profundidades dos aparelhos. 
A partir dos mesmos conceitos utilizados no experimento de balanço hídrico para a comunidade de 40 plantas, utilizando a equação 2, e medindo-se todos os elementos desta equação, pode-se, variando o valor da profundidade z, estudar a retirada de água da cultura por ET, para as camadas de solo de espessura arbitrária. Este procedimento, simples à primeira vista, é difícil, principalmente no que se refere às medidas do fluxo de água no solo, por depender do conhecimento detalhado das propriedades hídricas do perfil de solo. Estas propriedades hídricas foram medidas segundo procedimento já citado nos itens 3.2.1 e 3.2.2, resultando nas equações apresentadas nas Tabelas 1 e 2. O armazenamento de água por camada foi quantificado utilizando as equações constadas na Tabela 1, a partir das medidas obtidas pelos tensiômetros. Os fluxos de drenagem ou ascensão capilar foram medidos utilizando as equações apresentadas na Tabela 2 e os gradientes medidos.

As profundidades escolhidas para a totalização do armazenamento foram $0,40,0,60,0,80,1,00$ e $1,10 \mathrm{~m}$. Os fluxos por camada foram obtidos utilizando-se a equação 7. Para a profundidade $0,40 \mathrm{~m} \circ$ gradiente foi determinado pelos potenciais totais das profundidades de 0,20 e 0,60 m. Para a profundidade $0,60 \mathrm{~m}$, pelos potenciais das profundidades 0,80 e 0,40 m. Para a profundidade de 0,80 , das profundidades 1,00 e 0,60 m. Para a profundidade 1,00 , das profundidades 1,10 e $0,80 \mathrm{~m}$. E para a profundidade 1,10 , pelos potenciais obtidos para as profundidades de 1,20 e 1,00 m. Conforme citado acima, as condutividades hidráulicas adotadas foram obtidas em experimento adjacente a área em estudo pelo método do perfil instantâneo (Tabela 2).

A precipitação pluviométrica foi obtida pelo uso de um pluviômetro instalado à cerca de $5 \mathrm{~m}$ do experimento (item 3.5.1)

Foram escolhidos dois períodos para o monitoramento da extração de água por uma planta de citros. O primeiro, realizado entre os dias 09/02/2002 e 20/03/2002 (considerado período úmido) e o segundo entre os dias 01/04/2002 e 07/05/2002 (considerado período seco). 


\subsubsection{Medidas de Posição e Dispersão}

Quando falamos de dispersão, procuramos uma indicação de como estão concentrados os dados.

Dispersão dos quartos $=$ Quarto superior - Quarto inferior

$\mathrm{d}_{\mathrm{F}} \quad=\quad \mathrm{F}_{\mathrm{S}} \quad-\quad \mathrm{F}_{\mathrm{I}}$

Esta amplitude também reflete a dispersão, mas valores estranhos influenciam a amplitude. A identificação de "outliers" necessita de uma medida de dispersão que seja insensível a eles. A dispersão-F fornece tal medida. Utilizamos a dispersão do quarto, $d_{F}$, como uma medida de distância e posição de um múltiplo, especificamente $11 / 2$, de seu ascendente de $F_{S}$ e descendente de $F_{1}$. Estabelecemos assim os limites críticos da amostra. Examinamos com atenção os "fora dos limites", merecedores de um exame mais minuncioso.

\subsection{3 "Boxplots"}

É um dispositivo gráfico do resumo de 5-números de um grupo de dados, e mostra muito da estrutura do grupo. Deste gráfico podemos tomar as seguintes características deste grupo:

- posição;

- dispersão;

- assimetria;

- distribuição;

- "outliers".

O "boxplot" mostra a posição, dispersão, assimetria, comprimento da cauda e "outliers". A posição do grupo é resumida pela mediana, a faixa no interior da caixa. O comprimento da cauda mostra a dispersão dos dados, dada pela dispersão-F. Das posições da mediana e dos quartos vemos um pouco de assimetria: a mediana estando muito mais próxima do quarto inferior que do quarto superior, indica que o grupo é positivamente assimétrico.

As propriedades de resistência do "boxplot" o tornam atrativo para uso em análise exploratória. Uma plotagem análoga poderia ser baseada na média 
e no desvio padrão amostrais, mas estas medidas falhariam na resitência a um único valor estranho.

Dessa modo, foi extraído um "boxplot" para cada período de leitura (14) arranjando-os paralelamente, de modo a podermos comparar os grupos quanto às suas características. A observação deste gráfico antes do estudo de verificação de "outliers", e depois desta, nos mostra o quanto os dados dos diferentes grupos não estão ajustados dentro da mesma escala. A posição do grupo é resumida pela mediana, a faixa no interior da caixa. O comprimento da caixa mostra a dispersão dos dados e das posições da mediana e dos quartos vemos um pouco de assimetria.

A eliminação ou não dos candidatos a "outliers" foi baseada na análise do reflexo desta eliminação na média e mediana dos dados do período considerado. Estas plantas também foram analisadas quanto a seu comportamento fisiológico ao longo do ano bem como sua produção e sua conseqüente eficiência de uso da água.

Para a realização das análises foi utilizado o programa estatístico Statística for Windows - Release 4.3 - Copyright StatSoft, Inc. 1993. 


\section{RESULTADOS E DISCUSSÃO}

Com o objetivo de organizar e melhorar a compreensão da análise e discussão dos resultados obtidos, separou-se a apresentação em dois experimentos distintos mas complementares: experimento 1, referente ao balanço hídrico realizado para as 40 plantas da transeção monitoradas; e experimento 2, referente ao balanço hídrico realizado em uma planta, distinguindo a contribuição por profundidade, bem como por distância em relação ao tronco e sentido em relação à linha de plantio.

No Experimento 1, foi realizada a análise estatística exploratória com o intuito da obtenção de um padrão de comportamento no que diz respeito ao consumo de água para toda a comunidade das 40 plantas monitoradas. Neste experimento trabalhou-se com o conceito de "outliers", verificando-se a existência de valores periféricos que poderiam estar prejudicando a obtenção deste procurado comportamento médio da transeção. Os efeitos da identificação dos "outliers" na análise de um conjunto de dados e os procedimentos para tratá-los de forma adequada foram descritos pela primeira vez no século dezenove. Recomenda-se a aplicação de procedimentos para identificar a existência de dados discrepantes antes de ser testada qualquer outra hipótese, pois a sua presença afetará os resultados de todos os testes estatísticos formais que utilizam resíduos, incluindo os de avaliação da variabilidade e normalidade (Ribeiro Junior, 1995). Dentre os diversos métodos e critérios para detecção de "outliers" (Czermainski, 1986), escolhemos aquele descrito por Libardi et al. (1996).

No Experimento 2, foi realizada a distinção da contribuição para o 
consumo de água pela cultura, por profundidade de exploração radicular bem como por distância do tronco, tanto em direção à linha como em direção à entrelinha. Nesta parte do experimento procurou-se apresentar em quais profundidades o sistema radicular da cultura de citros extrai mais água, bem como, sugerir por meio de uma análise espacial (pelo comportamento médio da umidade) em dois períodos de 37 dias (um úmido e outro menos úmido), em quais profundidades ocorre maior extração de água.

\subsection{Experimento do balanço hídrico no campo}

A coleta e tabulação dos dados foi realizada ao longo dos anos 2001 e 2002, de agosto à agosto, a fim de obter-se o comportamento do consumo de água pela cultura de citros desde a colheita do ano de 2001 até o término da colheita do ano de 2002, explicando suas variações ao longo do ciclo por suas mudanças de estágio fenológico. A totalização da ET foi realizada pela aplicação da equação 2, calculando-se a drenagem diariamente, a armazenagem a cada 7 dias (em média) e a precipitação pluvial também diariamente. Optou-se pela análise estatística descritiva dos valores de ET por períodos que variam de 21 a 63 dias, com o objetivo da obtenção de um comportamento médio da comunidade de plantas. O comportamento médio obtido foi então comparado com aqueles apresentados pela bibliografia disponível.

\subsubsection{Análise exploratória dos dados}

A análise do conjunto de dados foi realizada pela estatística descritiva, com o intuito de se ter uma idéia sobre o comportamento do fenômeno estudado. Este procedimento foi realizado tendo como base os princípios da estatística clássica, cujo resumo estatístico fornece as informações das medidas de posição, dispersão e forma da distribuição de freqüência para 
verificação da normalidade dos dados. Considerando que os parâmetros que definem as principais características de um conjunto de dados estão sujeitos a perturbações por valores atípicos, Libardi et al. (1996) propõem o uso de técnicas complementares para a verificação da adequação das medidas anteriores por meio da identificação de candidatos a "outliers" e descrição do comportamento das variáveis que formam o conjunto de dados.

A proximidade entre os valores da média e mediana sinaliza que a ET apresenta distribuição aproximadamente simétrica para todos os períodos. Em se tratando de medidas de posição e de dispersão, é recomendado, para sua correta definição, que se observe mais de um parâmetro de estatística descritiva (Libardi et al., 1996). Desse modo, seguindo os critérios definidos por Jones (1969), ao nível de $5 \%$ de probabilidade, os coeficientes de assimetria e curtose indicam que a evapotranspiração seguiu uma distribuição normal para os quatorze períodos de tempo avaliados. Para complementar esta avaliação, observou-se o formato da distribuição dos dados por meio dos gráficos de dispersão e reta de Henry (Figuras 6 e 7).

Tabela 3. Análise estatística descritiva dos resultados de ET por período de avaliação, antes da verificação de valores periféricos.

\begin{tabular}{llcccccccccc}
\hline & & & & \multicolumn{7}{c}{ Quartil } & Quartil \\
Períodos & $N$ & Média & Mediana & Mínimo & Máximo & Inferior & Superior & Variância & Des.P & Assimetria & Curtose \\
\hline Per. 1 & 40 & 37.42 & 38.25 & 18.74 & 52.89 & 30.90 & 42.10 & 72.73 & 8.53 & 0.01 & -0.42 \\
Per. 2 & 40 & 32.91 & 32.16 & 23.24 & 47.68 & 28.64 & 36.49 & 31.22 & 5.59 & 0.67 & 0.01 \\
Per. 3 & 40 & 116.84 & 117.16 & 97.39 & 128.76 & 112.93 & 122.52 & 56.63 & 7.53 & -0.57 & 0.30 \\
Per. 4 & 40 & 58.98 & 57.53 & 41.36 & 77.46 & 54.28 & 63.19 & 51.13 & 7.15 & 0.19 & 0.35 \\
Per. 5 & 40 & 73.27 & 74.34 & 39.69 & 104.75 & 64.27 & 81.61 & 166.20 & 12.89 & -0.22 & 0.39 \\
Per. 6 & 40 & 108.98 & 112.02 & 82.93 & 128.20 & 101.56 & 116.36 & 123.16 & 11.10 & -0.60 & -0.33 \\
Per. 7 & 40 & 157.61 & 161.32 & 99.85 & 187.76 & 149.61 & 168.68 & 318.88 & 17.86 & -1.32 & 2.98 \\
Per. 8 & 40 & 256.60 & 260.86 & 214.26 & 278.72 & 252.80 & 263.80 & 159.28 & 12.62 & -1.37 & 2.31 \\
Per. 9 & 40 & 69.47 & 70.68 & 56.23 & 84.09 & 62.05 & 75.41 & 60.80 & 7.80 & -0.21 & -0.96 \\
Per.10 & 40 & 187.08 & 189.13 & 164.89 & 209.87 & 179.59 & 193.98 & 115.20 & 10.73 & -0.12 & -0.09 \\
Per.11 & 40 & 51.53 & 52.07 & 32.30 & 69.76 & 45.46 & 56.77 & 72.35 & 8.51 & -0.25 & -0.20 \\
Per.12 & 40 & 31.91 & 30.38 & 8.74 & 79.86 & 21.28 & 43.59 & 217.36 & 14.74 & 0.77 & 1.28 \\
Per.13 & 40 & 54.87 & 54.06 & 22.28 & 79.92 & 48.95 & 61.91 & 144.19 & 12.01 & -0.25 & 0.53 \\
Per.14 & 40 & 30.38 & 28.40 & 18.15 & 54.01 & 24.29 & 35.41 & 64.95 & 8.06 & 0.92 & 0.85 \\
\hline
\end{tabular}


A Tabela 3 apresenta a análise estatística preliminar dos resultados de ET por período de avaliação. As observações preliminares dos coeficientes de assimetria e curtose indicam que a curva é aproximadamente normal, levemente achatada e tendendo para a esquerda nos períodos 7,8 e 12, períodos em que os valores na reta de Henry parecem mais dispersos.
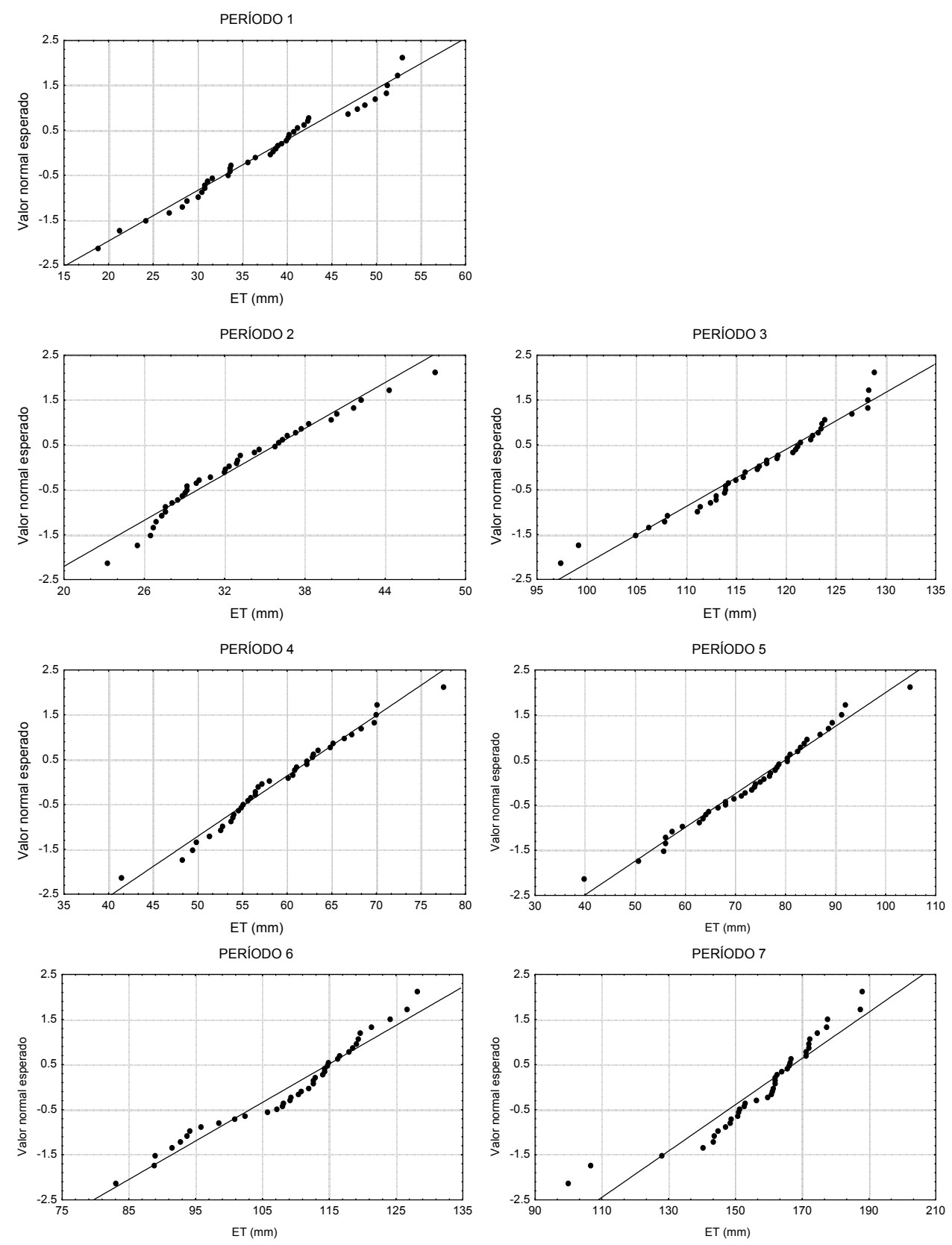

Figura 6 - Retas de probabilidade de Henry, para ET $(\mathrm{mm})$, dos períodos de análise 1 a 7. 

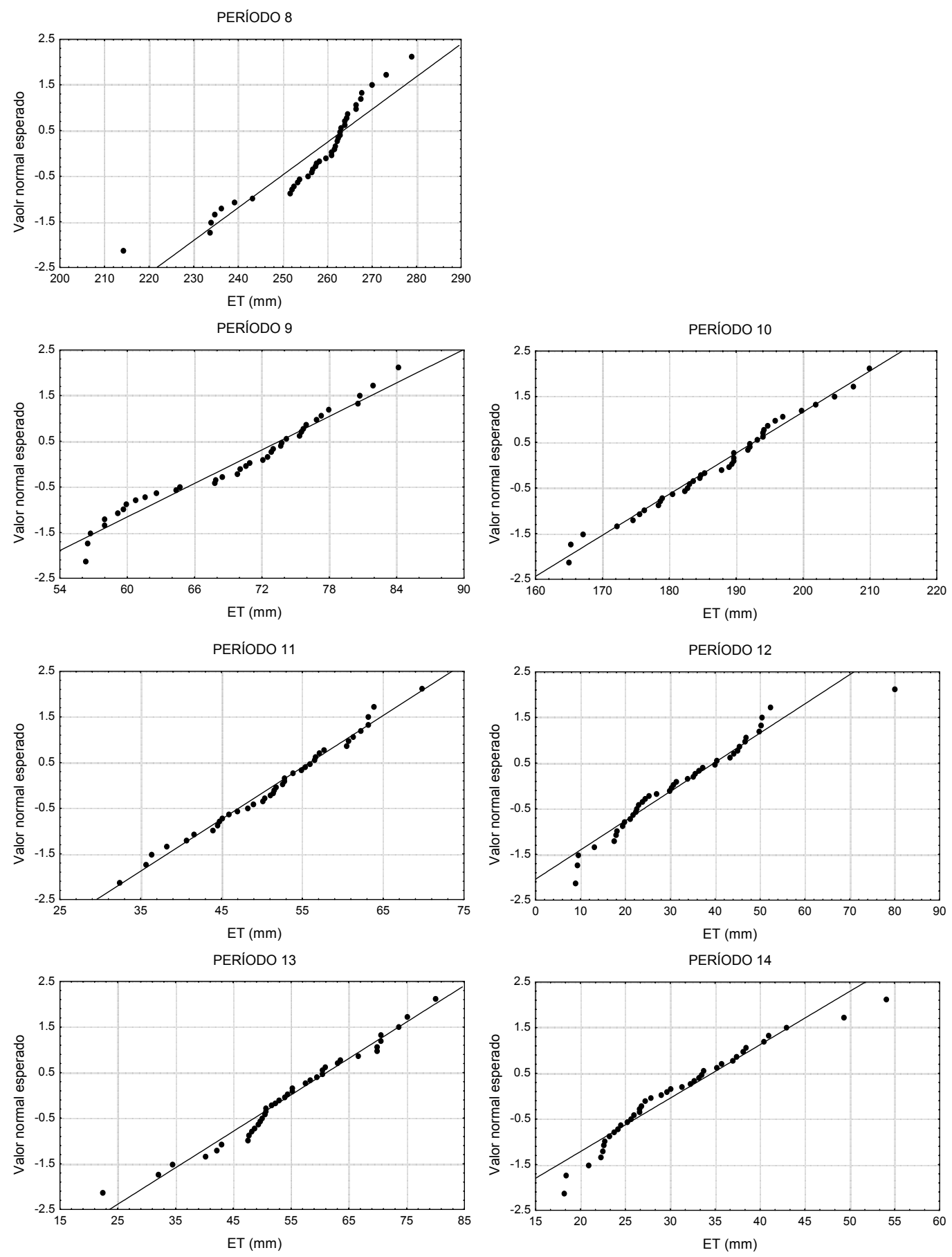

Figura 7 - Retas de probabilidade de Henry, para ET $(\mathrm{mm})$, dos períodos de análise 8 a 14.

O procedimento posterior da análise, a partir das suposições sobre possíveis valores periféricos candidatos a "outliers", originadas pelos resultados apresentados na Tabela 3, bem como suas influências sobre as medidas de 
posição e dispersão, foi a elaboração do resumo de 5 números (Figuras 9 e 10) e, com ele, a obtenção dos limites críticos. A vantagem deste dispositivo de análise foi obter o número de valores periféricos em cada período, bem como a identificação dos "outliers" que correspondem a valores com um comportamento diferente do apresentado pela maioria dos dados (Hoaglin, 1992).

De acordo com o que já havia sido concluído pelas retas de Henry e também pelo resumo estatístico preliminar, o resumo de 5 números para cada um dos 14 períodos de avaliação, mostra que os períodos 7,8 e 12 foram aqueles em que os limites críticos calculados eliminaram mais pontos de avaliação. Este dispositivo estatístico também verificou possível existência de valores periféricos nos períodos 3, 4 e 14. Eliminados sem restrições todos os possíveis candidatos a "outliers", foi elaborado um novo resumo estatístico para a verificação da influência destas eliminações na média dos períodos.

Tabela 4. Análise estatística descritiva dos resultados de ET por período de avaliação, após eliminação de valores periféricos.

\begin{tabular}{|c|c|c|c|c|c|c|c|c|c|c|c|}
\hline Períodos & $\mathrm{N}$ & Média & Mediana & Mínimo & Máximo & $\begin{array}{l}\text { Quartil } \\
\text { Inferior }\end{array}$ & $\begin{array}{l}\text { Quartil } \\
\text { Superior }\end{array}$ & Variância & Des.P & Assimetria & Curtose \\
\hline Per. 1 & 40 & 37.42 & 38.25 & 18.74 & 52.89 & 30.90 & 42.10 & 72.73 & 8.53 & 0.01 & -0.42 \\
\hline Per. 2 & 40 & 32.91 & 32.16 & 23.24 & 47.68 & 28.64 & 36.49 & 31.22 & 5.59 & 0.67 & 0.01 \\
\hline Per. 3 & 39 & 117.34 & 117.27 & 99.16 & 128.76 & 112.94 & 122.59 & 47.91 & 6.92 & -0.37 & 0.01 \\
\hline Per. 4 & 39 & 58.50 & 57.09 & 41.36 & 70.08 & 54.03 & 62.92 & 43.25 & 6.58 & -0.14 & -0.08 \\
\hline Per. 5 & 40 & 73.27 & 74.34 & 39.69 & 104.75 & 64.27 & 81.61 & 166.20 & 12.89 & -0.22 & 0.39 \\
\hline Per. 6 & 40 & 108.98 & 112.02 & 82.93 & 128.20 & 101.56 & 116.36 & 123.16 & 11.10 & -0.60 & -0.33 \\
\hline Per. 7 & 38 & 160.48 & 161.55 & 127.81 & 187.76 & 150.49 & 168.68 & 167.02 & 12.92 & -0.10 & 0.15 \\
\hline Per. 8 & 35 & 260.33 & 261.63 & 239.16 & 278.72 & 256.31 & 264.22 & 58.17 & 7.63 & -0.46 & 1.54 \\
\hline Per. 9 & 40 & 69.47 & 70.68 & 56.23 & 84.09 & 62.05 & 75.41 & 60.80 & 7.80 & -0.21 & -0.96 \\
\hline Per.10 & 40 & 187.08 & 189.13 & 164.89 & 209.87 & 179.59 & 193.98 & 115.20 & 10.73 & -0.12 & -0.09 \\
\hline Per.11 & 40 & 51.53 & 52.07 & 32.30 & 69.76 & 45.46 & 56.77 & 72.35 & 8.51 & -0.25 & -0.20 \\
\hline Per.12 & 37 & 33.75 & 31.18 & 12.94 & 79.86 & 22.32 & 43.59 & 188.79 & 13.74 & 1.01 & 1.84 \\
\hline Per.13 & 40 & 54.87 & 54.06 & 22.28 & 79.92 & 48.95 & 61.91 & 144.19 & 12.01 & -0.25 & 0.53 \\
\hline Per.14 & 40 & 30.38 & 28.40 & 18.15 & 54.01 & 24.29 & 35.41 & 64.95 & 8.06 & 0.92 & 0.85 \\
\hline
\end{tabular}

A Tabela 4 acima apresenta os valores de ET por período de avaliação. A atitude extrema tomada, rejeitando-se todos os candidatos a "outliers", refletiu-se apenas na média de ET nos períodos 7, 8 e 12. As variâncias, dentro de cada período de avaliação, diminuíram após a retirada dos valores 
periféricos, mas apresentaram a mesma tendência nas duas tabelas, isto é, aumentando nos períodos do ano em que o estágio fenológico da cultura exigiu maior quantidade de água e diminuindo à medida que a necessidade hídrica da cultura reduziu em função do termino de seu ciclo anual.

\begin{tabular}{|c|c|c|c|c|c|c|}
\hline \multirow{3}{*}{$\begin{array}{l}\# 40 \\
\text { M } 20.5 \\
F \quad 11\end{array}$} & \multicolumn{2}{|r|}{ Período 1} & \multirow{3}{*}{$\begin{array}{l}\# 40 \\
M \quad 20.5 \\
F \quad 11\end{array}$} & $\mathrm{ET}(\mathrm{mm})$ & \multicolumn{2}{|l|}{ Período 2} \\
\hline & \multicolumn{2}{|r|}{38.25} & & \multicolumn{3}{|c|}{32.16} \\
\hline & 30.90 & 42.09 & & 28.64 & \multicolumn{2}{|r|}{36.49} \\
\hline & 18.73 & 52.89 & & 23.24 & & 47.68 \\
\hline & & $1.5 \mathrm{dF}=$ & & \multirow{3}{*}{$\begin{array}{l}d F= \\
d F=\end{array}$} & $1.5 \mathrm{dF}=$ & \multirow[t]{3}{*}{11.77} \\
\hline & $\mathrm{dF}=$ & \multirow{2}{*}{$42.09-30.90$} & & & \multirow{2}{*}{$\begin{array}{l}36.49-28.64 \\
7.85\end{array}$} & \\
\hline & $\mathrm{dF}=$ & & & & & \\
\hline & \multicolumn{2}{|c|}{ Limites críticos: } & & \multicolumn{3}{|c|}{ Limites críticos: } \\
\hline & Inferior: & 14.11 & & \multicolumn{3}{|c|}{ Inferior: $\quad 16.87$} \\
\hline & Superior: & 58.88 & & Superior: & \multicolumn{2}{|l|}{48.26} \\
\hline & \multicolumn{2}{|c|}{ "O utliers" : - } & & \multicolumn{3}{|c|}{ "O utliers" : - } \\
\hline & $\mathrm{ET}(\mathrm{mm})$ & Período 3 & & $\mathrm{ET}(\mathrm{mm})$ & Período 4 & \\
\hline \# 40 & & 117.16 & \# 40 & & 57.53 & \\
\hline $\begin{array}{l}\text { M } 20.5 \\
F\end{array}$ & 11203 & & M 20.5 & & & \\
\hline & 112.93 & 122.52 & F 11 & 54.28 & & 63.19 \\
\hline & 97.39 & 128.76 & & 41.36 & & 77.46 \\
\hline & & $1.5 \mathrm{dF}=14.39$ & & & $1.5 \mathrm{dF}=$ & 13.36 \\
\hline & $\mathrm{dF}=$ & $122.52-112.93$ & & $\mathrm{dF}=$ & $63.19-54.28$ & \\
\hline & $\mathrm{dF}=$ & 9.59 & & $\mathrm{dF}=$ & 8.91 & \\
\hline & Limites crí & icos: & & Limites $\mathrm{cr}$ & cos: & \\
\hline & Inferior: & 98.54 & & Inferior: & 40.92 & \\
\hline & Superior: & 136.91 & & Superior: & 76.55 & \\
\hline & "O utliers" : & Ponto 24 & & "O utliers" & Ponto 27 & \\
\hline & $\mathrm{ET}(\mathrm{mm})$ & Período 5 & & $\mathrm{ET}(\mathrm{mm})$ & Período 6 & \\
\hline \# 40 & & 74.34 & \# 40 & & 112.02 & \\
\hline M 20.5 & & & M 20.5 & & & \\
\hline F 11 & 64.26 & 81.61 & F 11 & 101.56 & & 116.36 \\
\hline & 39.69 & 104.75 & & 82.93 & & 128.19 \\
\hline & & $1.5 \mathrm{dF}=$ & & & $1.5 \mathrm{dF}=$ & 22.20 \\
\hline & $\mathrm{dF}=$ & $81.61-64.26$ & & $\mathrm{dF}=$ & $116.36-101$. & 56 \\
\hline & $\mathrm{dF}=$ & 17.35 & & $\mathrm{dF}=$ & 14.80 & \\
\hline & Limites crí & icos: & & Limites cr & cos: & \\
\hline & Inferior: & 38.24 & & Inferior: & 79.36 & \\
\hline & Superior: & 107.63 & & Superior: & 138.56 & \\
\hline & "O utliers" : & - & & "O utliers" & & \\
\hline & $\mathrm{ET}(\mathrm{mm})$ & Período 7 & & $\mathrm{ET}(\mathrm{mm})$ & Período 8 & \\
\hline \# 40 & & 161.31 & \# 40 & & 260.86 & \\
\hline M 20.5 & & & M 20.5 & & & \\
\hline F 11 & & & F 11 & 252.80 & & 263.80 \\
\hline & 99.85 & 187.76 & & 214.25 & & 278.72 \\
\hline & & $1.5 \mathrm{dF}=28.62$ & & & $1.5 \mathrm{dF}=$ & 16.50 \\
\hline & $\mathrm{dF}=$ & $168.69-149.61$ & & $\mathrm{dF}=$ & $263.8-252.8$ & \\
\hline & $\mathrm{dF}=$ & 19.08 & & $\mathrm{dF}=$ & 11.00 & \\
\hline & Limites crí & icos: & & Limites $\mathrm{cr}$ & cos: & \\
\hline & Inferior: & 120.99 & & Inferior: & 236.3 & \\
\hline & Superior: & 197.31 & & Superior: & 280.3 & \\
\hline & "Outliers" : & Pontos 3 e 4 & & "O utliers" & Pontos $1,3,4$, & 5 e 12 \\
\hline
\end{tabular}

Figura 9 - Resumo de 5 números para os períodos 1, 2, 3, 4, 5, 6, 7 e 8, com respectivo estudo de candidatos 'a "outliers". 


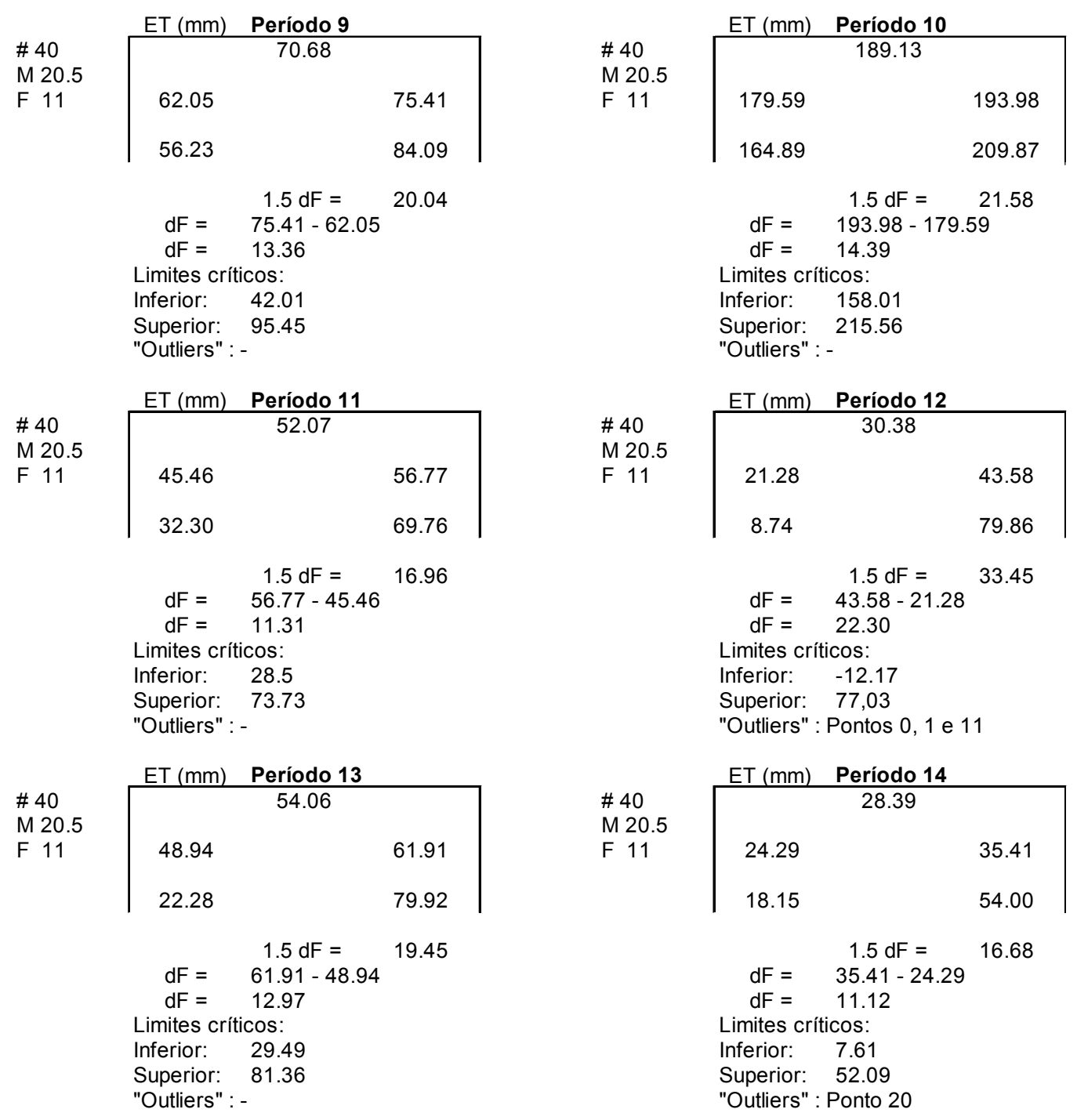

Figura 10 - Resumo de 5 números para os períodos 9 , 10,11, 12, 13 e 14, com respectivo estudo de candidatos 'a "outliers".

No período 12, quando a análise verificou o maior números de valores periféricos, a redução do desvio padrão após a eliminação destes valores foi acentuada, confirmando como correta esta atitude.

Os gráficos "Box-Plot" elaborados para cada período de avaliação, antes e depois da verificação e eliminação dos valores periféricos (Gráficos 1 e 2) mostram também o reflexo acentuado na redução do afastamento entre os quartis e a mediana. Estes gráficos também apresentam a variação da ET ao 
longo do ano e sua alteração conforme a necessidade hídrica da cultura. A observação atenta do Gráfico 1 evidencia elevado afastamento entre os quartis inferiores e a mediana nos períodos 7 e 8 , períodos coincidente com o estágio fenológico de pegamento e início do crescimento do fruto. No período 12 , o quartil superior é o mais afastado da mediana, fato acontecido somente neste período, quando nos demais períodos os valores periféricos concentram-se abaixo da mediana.

Outra evidência interessante e que foi levada em consideração na eliminação de valores periféricos é que todos os pontos (plantas) eliminados estão entre os 10 de menor produtividade e eficiência de uso da água. Os valores periféricos de ET obtidos nestes pontos ocorrem nos períodos 7 e 8 , períodos de maior consumo de água (pegamento e início do crescimento do fruto) e estão abaixo e distantes da mediana, evidenciando possíveis fatores da planta que diminuem o consumo de água da cultura. Este fato será novamente abordado mais adiante.

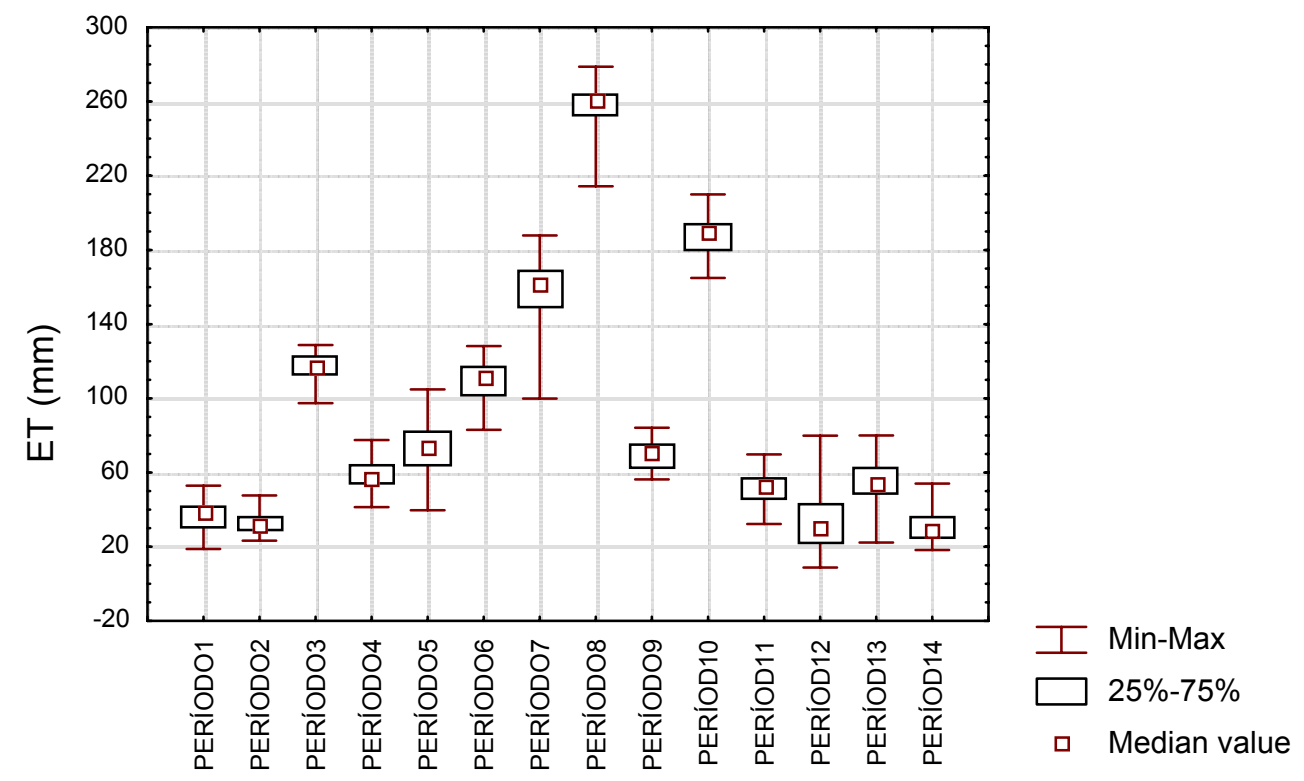

Gráfico 1 - Gráfico da ET por período, com os dispositivos "BoxPlot", antes da eliminação de "outliers".

Obtido o comportamento médio da comunidade de plantas (40 plantas 
nas duas transeções), a partir da análise exploratória dos resultados partiu-se para a avaliação do comportamento da cultura em termos de consumo hídrico total do ciclo nos estágios fenológicos da cultura mostrados no Gráfico 2.

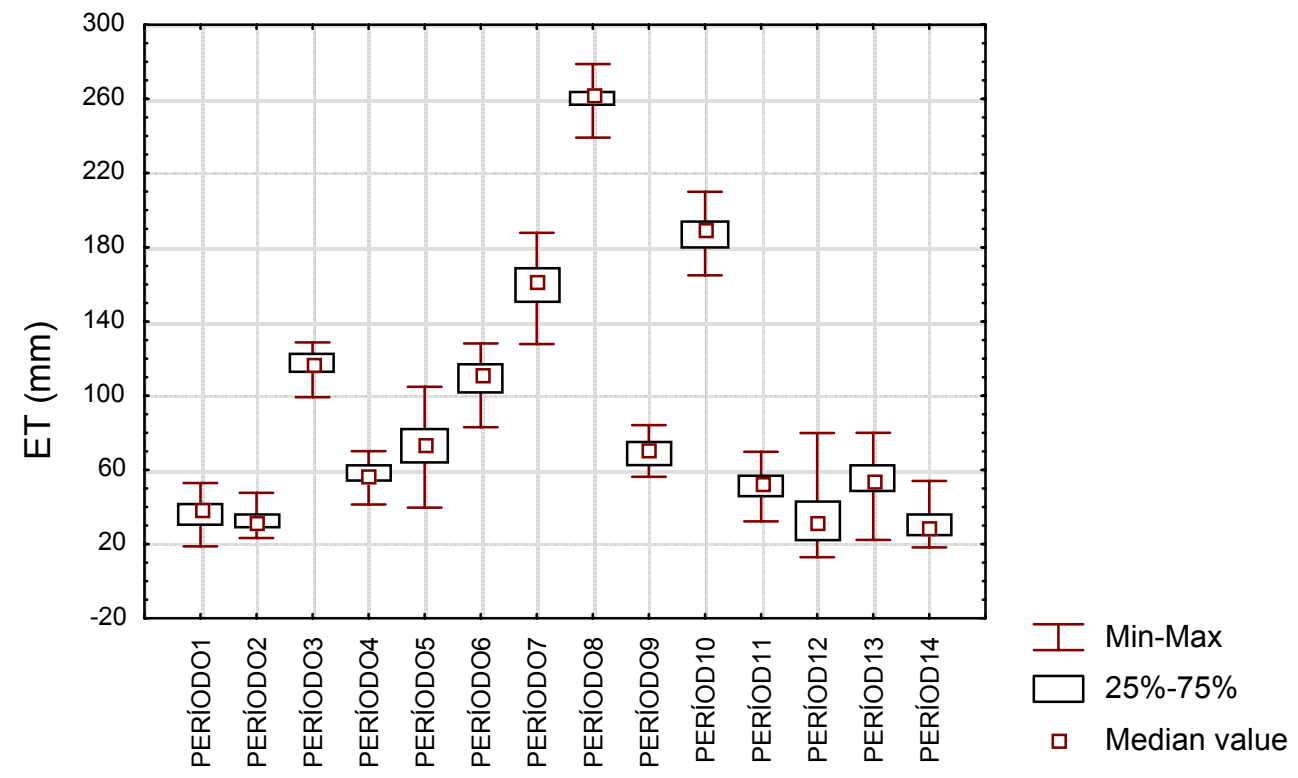

\footnotetext{
A S O N D J F M A M J J

Pré-florescimento Pegamento Crescimento Maturaçăo

Gráfico 2 - Gráfico da ET por período, com os dispositivos "BoxPlot" e distinção dos estágios fenológicos da cultura de citros, depois da eliminação de "outliers".
}

\subsubsection{Os processos do balanço hídrico}

$\mathrm{Na}$ totalização da ET para o ciclo anual da cultura de citros houve a necessidade de realizar um pequeno ajuste. Como o monitoramento iniciou no dia 09/08/2001 e o término das avaliações ocorreram no dia 21/08/2002, calculou-se a ET diária do último período, descontando-se o valor referente aos 12 dias sobrepostos. O valor total encontrado foi de $1271,45 \mathrm{~mm}$. Feito o ajuste no valor total de consumo de água pela cultura de citros, verifica-se que o comportamento médio das 40 plantas monitoradas é bastante semelhante àquele encontrado por Rogers et al. (1983) e também por Koo \& Hurner (1969), para as condições da Florida em solo de textura média como o estudado neste 
trabalho. Hoffman et al. (1982), no Arizona, local de clima semi-árido, encontraram valores de ET da ordem de $1470 \mathrm{~mm}$, bem superior à média encontrada.

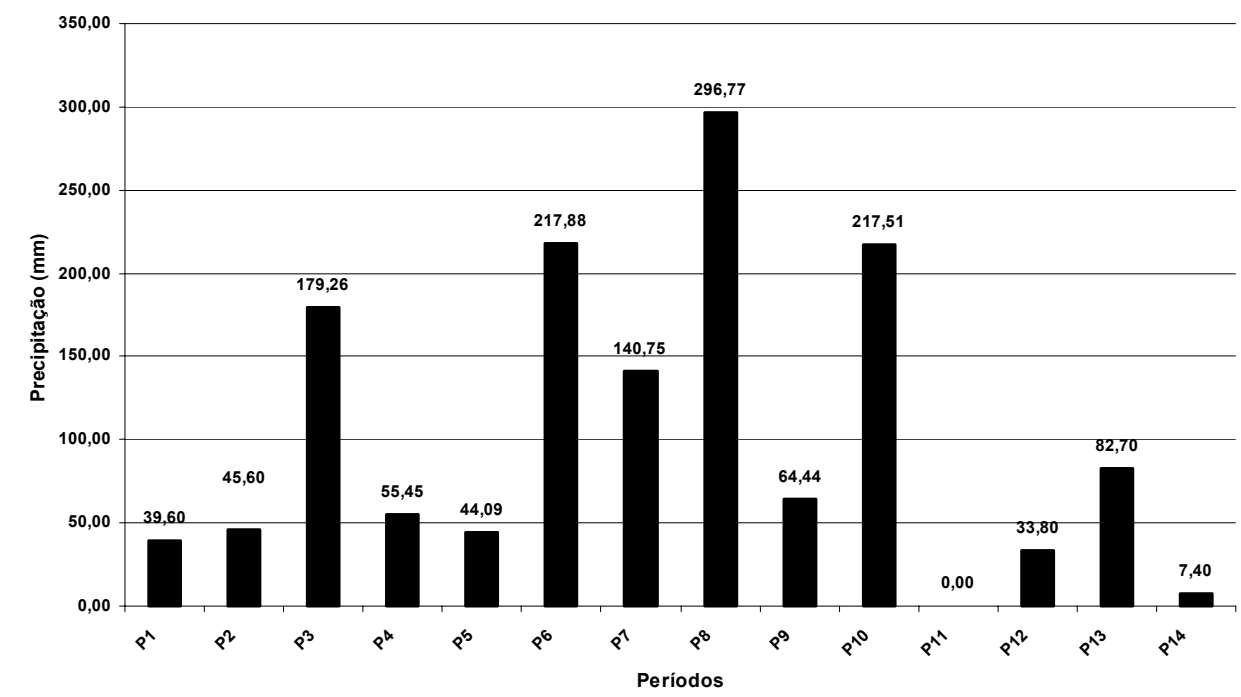

Gráfico 3 - Precipitação pluvial ocorrida ao longo dos 14 períodos de monitoramento, medida em pluviôgrafo instalado em área adjacente.

O Gráfico 3 apresenta a precipitação ocorrida durante o período de monitoramento. A quantidade total de chuva foi de $1429,25 \mathrm{~mm}$, bem próximo da média dos últimos anos, durante o período de monitoramento (agosto a agosto). A Tabela 5 apresenta a precipitação ocorrida nos últimos 9 anos, período de agosto a agosto, medida no Posto Meteorológico da ESALQ/USP.

Tabela 5. Precipitação pluviométrica ocorrida nos últimos 9 anos, durante o período de monitoramento.

\begin{tabular}{lccc}
\hline Anos & Ago - Dez $^{*}$ & ${\text { Jan }- \text { Jul }^{*}}^{*}$ & Total \\
\hline $1993-94$ & 517,60 & 744,40 & 1262,00 \\
$1994-95$ & 637,30 & 1040,00 & 1677,30 \\
$1995-96$ & 607,50 & 793,50 & 1401,00 \\
$1996-97$ & 797,70 & 729,30 & 1527,00 \\
$1997-98$ & 629,80 & 816,00 & 1445,80 \\
$1998-99$ & 613,40 & 1003,50 & 1616,90 \\
$1999-2000$ & 436,40 & 616,90 & 1053,30 \\
$2000-01$ & 725,20 & 618,30 & 1343,50 \\
$2001-02$ & 622,50 & 945,70 & 1568,20 \\
Média & - & - & 1432,78 \\
\hline
\end{tabular}

"Dados do Posto Meteorológico da ESALQ/USP. 
Observa-se que a precipitação ocorrida no último ano foi normal e bem próxima da média dos últimos 9 anos, para o período do ano monitorado. Conforme observado, o período mais seco ocorre entre os meses de abril e setembro, sendo abril o mês mais seco. Os meses mais chuvosos foram dezembro, janeiro, fevereiro e março, e o total das chuvas do mês mais seco não ultrapassou $30 \mathrm{~mm}$ (P11, P12, P13, P14 e P1). A ET total medida correspondeu a cerca de $89 \%$, em média, da precipitação fato também observado nos estudos realizados nos Estados Unidos.

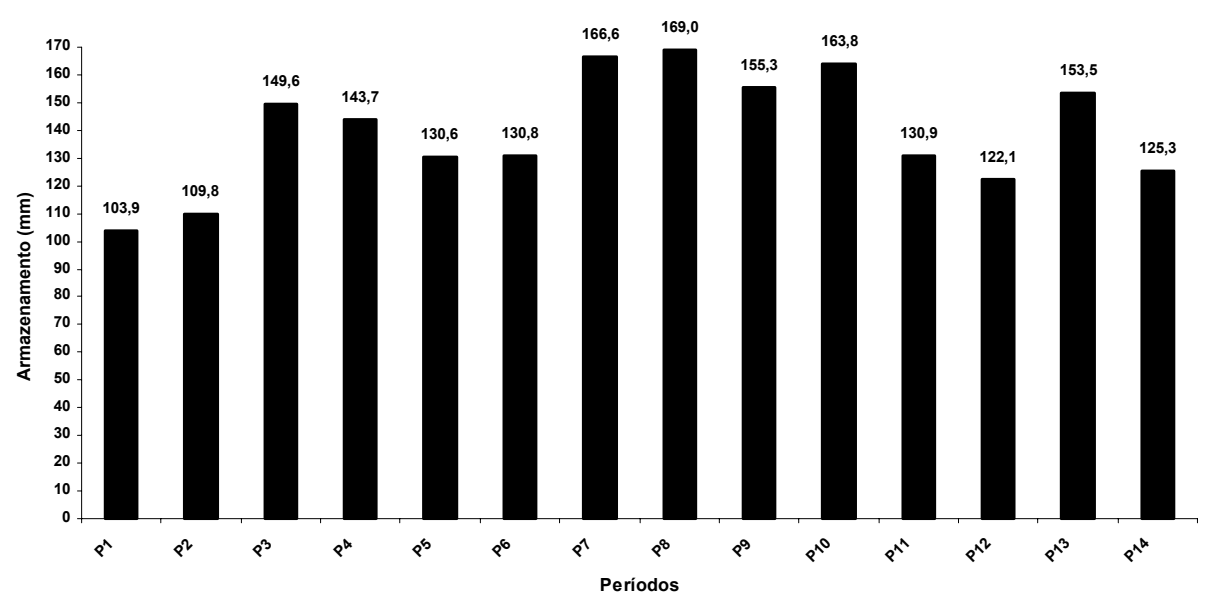

Gráfico 4 - Armazenamento médio de água no solo para a camada de solo de $1,10 \mathrm{~m}$, durante o período do monitoramento.

O Gráfico 4 apresenta o armazenamento médio para a camada de $1,10 \mathrm{~m}$, durante os 14 períodos estudados. A armazenagem de água no solo reflete as variações da precipitação pluviométrica ao longo do ano monitorado.

O mesmo gráfico foi construído para os oito pontos considerados "outliers" no estudo estatístico dos resultados de ET (Figura 11); neles observase que também não houve diferenças importantes no armazenamento de água no solo ao longo do ciclo, que justifique o menor consumo de água e o conseqüente comportamento discrepante no grupo de dados. Esta observação reforça a desconfiança de que fatores de planta foram os causadores da discrepância. 

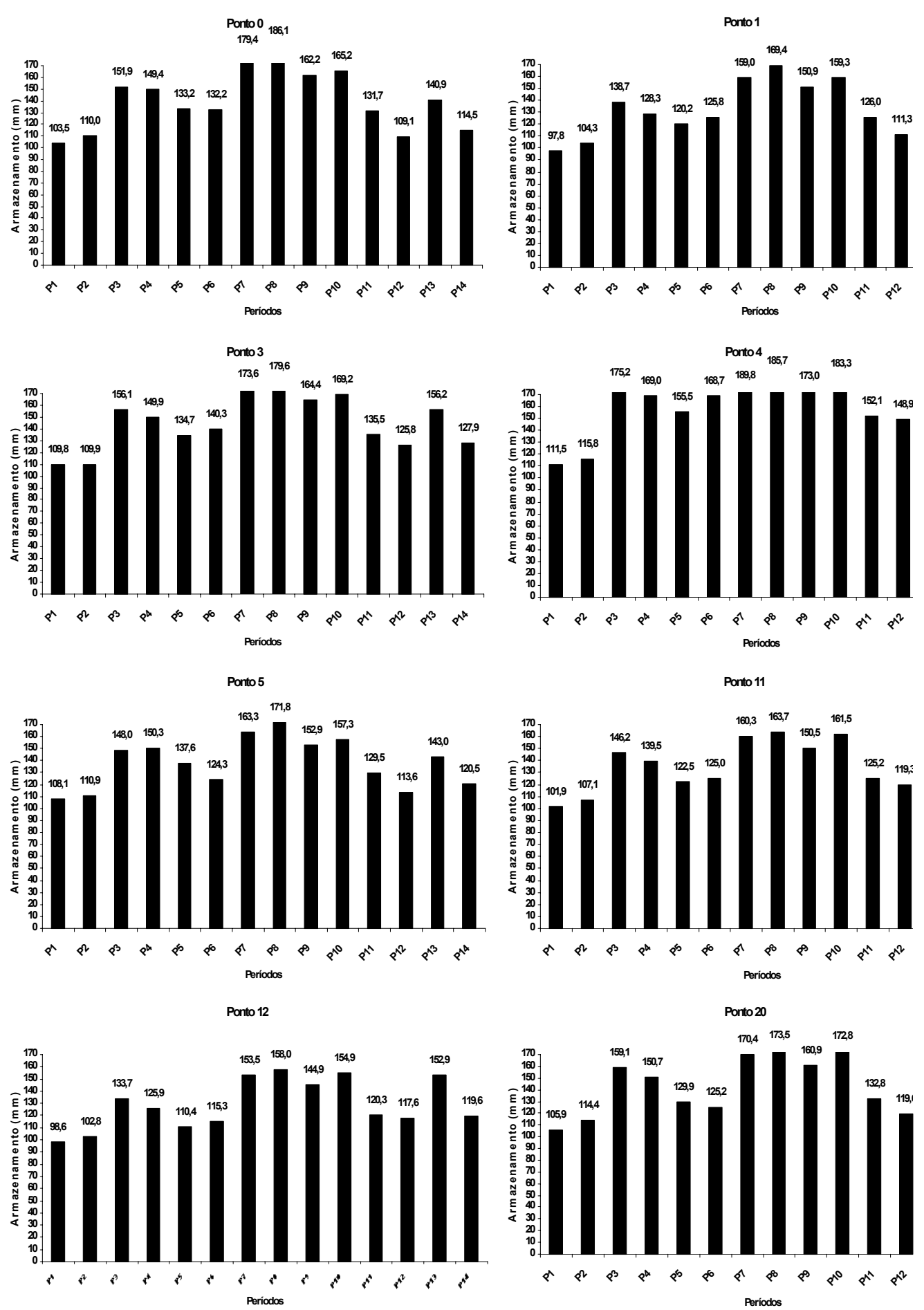

Figura 11 - Gráficos do armazenamento da água no solo para a camada de 0,0 m a 1,10 $\mathrm{m}$ de profundidade dos oito pontos eliminados devido a valores periféricos de ET. 
Prof. $\mathbf{0 , 6 0} \mathrm{m}$

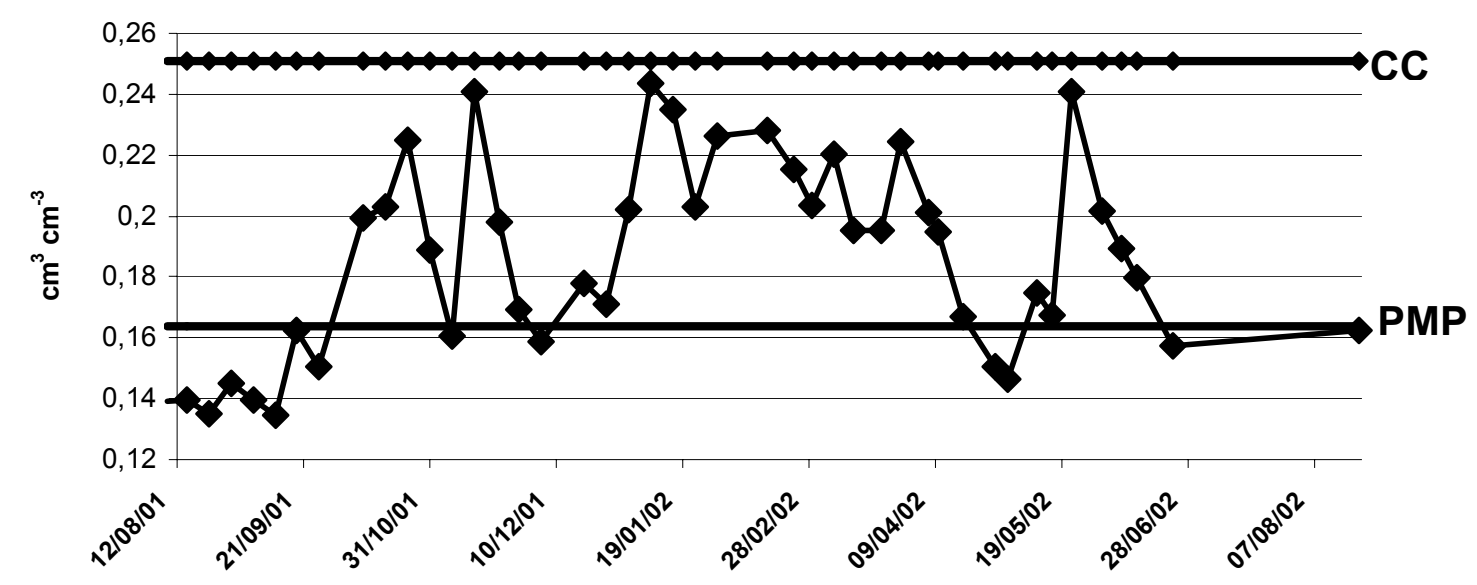

Gráfico 5 - Umidade média em função do tempo para a camada de $0-0,60 \mathrm{~m}$ durante o ciclo da cultura. As linhas horizontais indicam a umidade no Ponto de Murcha Permanente (PMP) e na Capacidade de Campo (CC).

Embora contendo todas as restrições aos conceitos de água disponível, principalmente no que diz respeito aos limites considerados, (ao ponto de murcha permanente, muitas vezes a planta já manifesta sintomas de deficiência hídrica mesmo antes de ser atingido o potencial de 150 m.c.a., e à capacidade de campo que pode não ser limitante se não houver restrição de oxigenação para as raízes, ou o inverso), muito bem discutidos em van Lier (2000), em Pereira et al.(1974), foi considerada como água disponível aquela retida a potenciais acima de 150 m.c.a. O Gráfico 5 nos dá uma boa idéia das respostas do solo às condições atmosféricas. É importante assinalar que a cultura de citros tem necessidade da ocorrência de pequeno déficit hídrico para sua adequada floração e frutificação pois não havendo um inverno rigoroso como acontece no hemisfério norte a indução floral dá-se pelo déficit hídrico. A relação entre o grau de floração e de crescimento vegetativo posterior depende da intensidade da deficiência no período de repouso (Angelocci, 2000; 
Doorenbos \& Kassan, 1979; Reuther, 1973). Neste ciclo monitorado, os períodos de déficit ocorrem nos meses de setembro de 2001 e maio de 2002 . O déficit de maio acontece em pré-florescimento justamente no momento da indução floral e o déficit de setembro ocorre em fase de colheita sem reflexos na produção final. A comparação entre os Gráficos 4 e 5 mostra que a deficiência hídrica ocorre nos períodos 1 e 2 (pré-florescimento), 11 e 12 (maturação).

A Tabela 6 apresenta um resumo da análise estatística dos dados de fluxo monitorados durante os 14 períodos. Observa-se que o coeficiente de variação é elevado, chegando a $112 \%$ no período 1 , com média de $56 \%$. Segundo classificação de Warrick \& Nielsen (1980) este coeficiente é considerado médio e justificável dado às restrições observadas por outros autores em relação ao uso da equação de Darcy.

Tabela 6. Análise estatística dos valores de drenagem de água $(\mathrm{mm})$ nos 14 períodos monitorados.

\begin{tabular}{lccccc}
\hline Períodos & Média & Mínimo & Máximo & $\begin{array}{c}\text { Desv. } \\
\text { Padrão }\end{array}$ & CV \% \\
\hline Período 1 & $-0,76$ & $-15,49$ & 16,19 & 0,85 & $-112,40$ \\
Período 2 & $-0,38$ & $-6,15$ & 8,46 & 0,37 & $-97,84$ \\
Período 3 & 0,00 & 0,00 & 0,00 & 0,00 & 0,00 \\
Período 4 & $-7,01$ & $-24,46$ & 20,37 & 0,92 & $-13,20$ \\
Período 5 & $-14,96$ & $-45,19$ & 7,45 & 11,94 & $-79,80$ \\
Período 6 & $-17,68$ & $-35,98$ & $-1,21$ & 8,45 & $-47,78$ \\
Período 7 & $-31,47$ & $-99,00$ & $-11,64$ & 16,36 & $-51,98$ \\
Período 8 & $-11,00$ & $-45,38$ & $-1,21$ & 7,66 & $-69,63$ \\
Período 9 & $-13,68$ & $-32,79$ & 1,89 & 8,55 & $-62,48$ \\
Período 10 & $-29,03$ & $-53,16$ & $-8,06$ & 10,47 & $-36,06$ \\
Período 11 & $-3,60$ & $-20,87$ & 24,82 & 0,91 & $-25,32$ \\
Período 12 & $-0,24$ & $-32,78$ & 34,91 & 0,14 & $-56,52$ \\
Período 13 & $-12,04$ & $-31,79$ & 15,85 & 9,71 & $-80,62$ \\
Período 14 & $-2,99$ & $-6,70$ & 1,13 & 1,74 & $-58,20$ \\
Total & $-144,84 \mathrm{~mm}$ & & & & \\
\hline
\end{tabular}




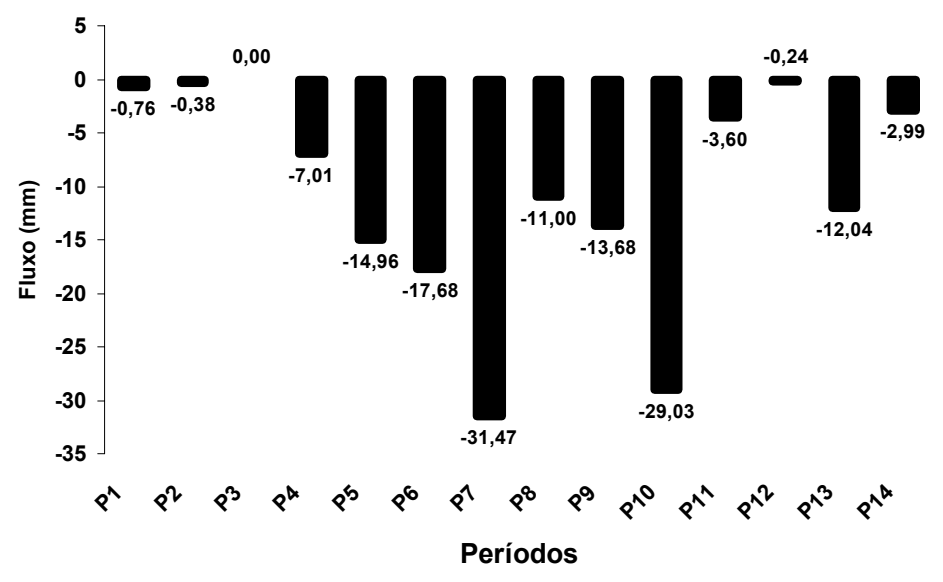

Gráfico 6 - Drenagem média ao longo dos 14 períodos monitorados.

O comportamento médio da drenagem de água abaixo da profundidade de $1,10 \mathrm{~m}$ para as 40 plantas de citros monitoradas é apresentado no Gráfico 6 . Observa-se que ao longo do ciclo não ocorre ascensão de água, havendo sempre drenagem de água não retida e não consumida pela evaporação do solo ou transpiração da cultura. O período de maior drenagem foi o período 7 , quando a precipitação foi elevada $(141 \mathrm{~mm})$, após um período também de elevada precipitação, tendo ocorrido, possivelmente, defasagem no tempo de drenagem de um período para o outro. No período 8 verifica-se a ocorrência de drenagem menor que o período anterior, quando neste período a precipitação também foi alta. Este período é aquele em que ocorre o maior consumo de água do ciclo, coincidindo com o estágio de pegamento e início de crescimento do fruto.

É interessante ressaltar que os trabalhos referidos de Rogers et al. (1983), Koo \& Hurner (1969) e Hoffman et al. (1982) foram realizados com a utilização de lisímetros, aparelhos que não são sensíveis a detecção da ocorrência de ascensão capilar. Embora a formação da média dos fluxos de drenagem contenha momentos de fluxos de ascensão capilar, o comportamento médio da comunidade de 40 plantas é da ocorrência de drenagem ao longo de todo o ciclo. Fato este que parece tornar adequada a comparação dos resultados de experimentos conduzidos com o uso de lisímetros com os agora obtidos.

Do mesmo modo que foi feito para a totalização da ET, houve necessidade de ajustar o total do fluxo, em função dos 12 dias sobrepostos no 
monitoramento. O total de $144,84 \mathrm{~mm}$ foi reduzido para $144,36 \mathrm{~mm}$ de água drenado ao longo do ciclo da cultura representando cerca de $10 \%$ do total adicionado pelas chuvas, o que revela a importância da medida, muitas vezes considerada desprezível em outros experimentos (Rose, 1966). Estes fluxos de drenagem são considerados os de mais difícil determinação motivo alegado para seu desprezo. Vachaud et al. (1973) e Stone et al.(1973), consideraram que esta componente do balanço hídrico não deveria ser desprezada podendo constituir $30 \%$ ou mais do total, principalmente quando realizado em regiões de clima tropical, como no caso em questão.

$\mathrm{Na}$ Tabela 7 são apresentados os resultados de ET anual $\left(\mathrm{em} \mathrm{m}^{3}\right.$.ha $\left.{ }^{-1}\right)$, produção de frutos (em kg.ha-1 $\mathrm{ano}^{-1}$ ) e Eficiência de Uso da Água para as 40 plantas monitoradas. Os resultados obtidos são coerentes com aqueles obtidos e sugeridos por Doorenbos \& Kassan (1979) em levantamento realizado para FAO. Segundo seu trabalho os índices de E.U.A. para citros situam-se entre 2 e 5 , enquanto que neste estudo os índices obtidos variam entre 1,57 e 4,52, bastante próximos aos sugeridos pelos autores.

Tabela 7. Resultados de ET, produção e E.U.A. por planta monitorada, classificados em ordem crescente.

\begin{tabular}{cccccccccc}
\hline Ordem & $N^{\circ}$ planta & $\begin{array}{c}\text { ET } \\
\left(\mathrm{m}^{3} \cdot \mathrm{ha}^{-1}\right)\end{array}$ & $\begin{array}{c}\text { Prod. } \\
\left(\mathrm{kg} \cdot \mathrm{ha}^{-1}\right)\end{array}$ & $\begin{array}{c}\text { E.U.A. } \\
\left(\mathrm{kg} \cdot \mathrm{m}^{-3}\right)\end{array}$ & Ordem & $\mathrm{N}^{\circ}$ planta & $\begin{array}{c}\text { ET } \\
\left(\mathrm{m}^{3} \cdot \mathrm{ha}^{-1}\right)\end{array}$ & $\begin{array}{c}\text { Prod. } \\
\left(\mathrm{kg} \cdot \mathrm{ha}^{-1}\right)\end{array}$ & $\begin{array}{c}\text { E.U.A. } \\
\left(\mathrm{kg} \cdot \mathrm{m}^{-3}\right)\end{array}$ \\
\hline $1^{\circ}$ & 3 & 11433,28 & 18214,29 & 1,57 & $21^{\circ}$ & 2 & 12564,68 & 41157,14 & 3,22 \\
$2^{\circ}$ & 0 & 11599,77 & 24217,86 & 1,88 & $22^{\circ}$ & 22 & 11902,14 & 40625,00 & 3,29 \\
$3^{\circ}$ & 4 & 11986,39 & 21735,71 & 1,93 & $23^{\circ}$ & 28 & 11503,51 & 43853,57 & 3,45 \\
$4^{\circ}$ & 12 & 10672,28 & 25528,57 & 2,00 & $24^{\circ}$ & 8 & 11764,58 & 44471,43 & 3,58 \\
$5^{\circ}$ & 11 & 10434,94 & 25528,57 & 2,03 & $25^{\circ}$ & 29 & 11635,96 & 45825,00 & 3,63 \\
$6^{\circ}$ & 1 & 11634,88 & 26392,86 & 2,13 & $26^{\circ}$ & 20 & 12132,24 & 49650,00 & 3,77 \\
$7^{\circ}$ & 5 & 12025,32 & 28978,57 & 2,35 & $27^{\circ}$ & 37 & 11741,53 & 49664,29 & 3,85 \\
$8^{\circ}$ & 16 & 12603,31 & 31346,43 & 2,45 & $28^{\circ}$ & 19 & 12776,48 & 49410,71 & 3,88 \\
$9^{\circ}$ & 26 & 11540,39 & 30878,57 & 2,55 & $29^{\circ}$ & 36 & 12019,99 & 48567,86 & 3,90 \\
$10^{\circ}$ & 18 & 11752,57 & 32528,57 & 2,64 & $30^{\circ}$ & 30 & 11858,47 & 48675,00 & 3,91 \\
$11^{\circ}$ & 21 & 12710,27 & 33089,29 & 2,65 & $31^{\circ}$ & 31 & 11726,32 & 49914,29 & 3,93 \\
$12^{\circ}$ & 25 & 11294,37 & 34178,57 & 2,68 & $32^{\circ}$ & 39 & 11858,58 & 47535,71 & 3,95 \\
$13^{\circ}$ & 23 & 11867,83 & 34703,57 & 2,78 & $33^{\circ}$ & 33 & 12423,85 & 53517,86 & 4,01 \\
$14^{\circ}$ & 13 & 11854,79 & 35882,14 & 2,83 & $34^{\circ}$ & 32 & 12405,37 & 53946,43 & 4,03 \\
$15^{\circ}$ & 24 & 11519,31 & 35957,14 & 2,90 & $35^{\circ}$ & 15 & 11903,20 & 54007,14 & 4,04 \\
$16^{\circ}$ & 38 & 12401,72 & 36310,71 & 2,97 & $36^{\circ}$ & 35 & 12577,89 & 54092,86 & 4,06 \\
$17^{\circ}$ & 6 & 12152,65 & 38282,14 & 2,99 & $37^{\circ}$ & 7 & 11783,98 & 57885,71 & 4,24 \\
$18^{\circ}$ & 14 & 12758,43 & 37482,14 & 3,01 & $38^{\circ}$ & 17 & 12176,90 & 59253,57 & 4,38 \\
$19^{\circ}$ & 9 & 11533,17 & 38207,14 & 3,08 & $39^{\circ}$ & 10 & 11174,11 & 61775,00 & 4,50 \\
$20^{\circ}$ & 34 & 11953,76 & 38739,29 & 3,20 & $40^{\circ}$ & 27 & 11452,15 & 61617,86 & 4,52 \\
\hline
\end{tabular}


O Gráfico 7 apresenta a correlação entre os resultados de ET por planta avaliada e sua produção final obtida. Observa-se que, ao nível de $5 \%$ de probabilidade, existe boa relação entre as variáveis. As plantas que obtiveram maior produção estavam entre aquelas que apresentaram maior consumo de água. Um coeficiente de correlação de 0,74 corrobora as conclusões retiradas.

Conforme já previamente comentado, as plantas que obtiveram menor consumo de água (ET) estavam entre as 10 plantas de menor produtividade (Tabela 7), fato que contribuiu para a eliminação de seus resultados da construção da média comportamental da comunidade de 40 plantas monitoradas. O motivo considerado foi a possibilidade de fatores de planta (agente fitopatológico) terem prejudicado a produção destas plantas e com isso diminuindo o consumo de água por elas. No que diz respeito ao tratamento de valores discrepantes num conjunto de dados, a avaliação pontual dos resultados, observando atentamente o comportamento da planta ao longo do ciclo é mais adequada que a adoção de artifícios matemáticos de análise. $\mathrm{O}$ controle e o conhecimento do pesquisador do estudo nesses casos, deve sempre ser o fator mais importante em tomada de decisões.

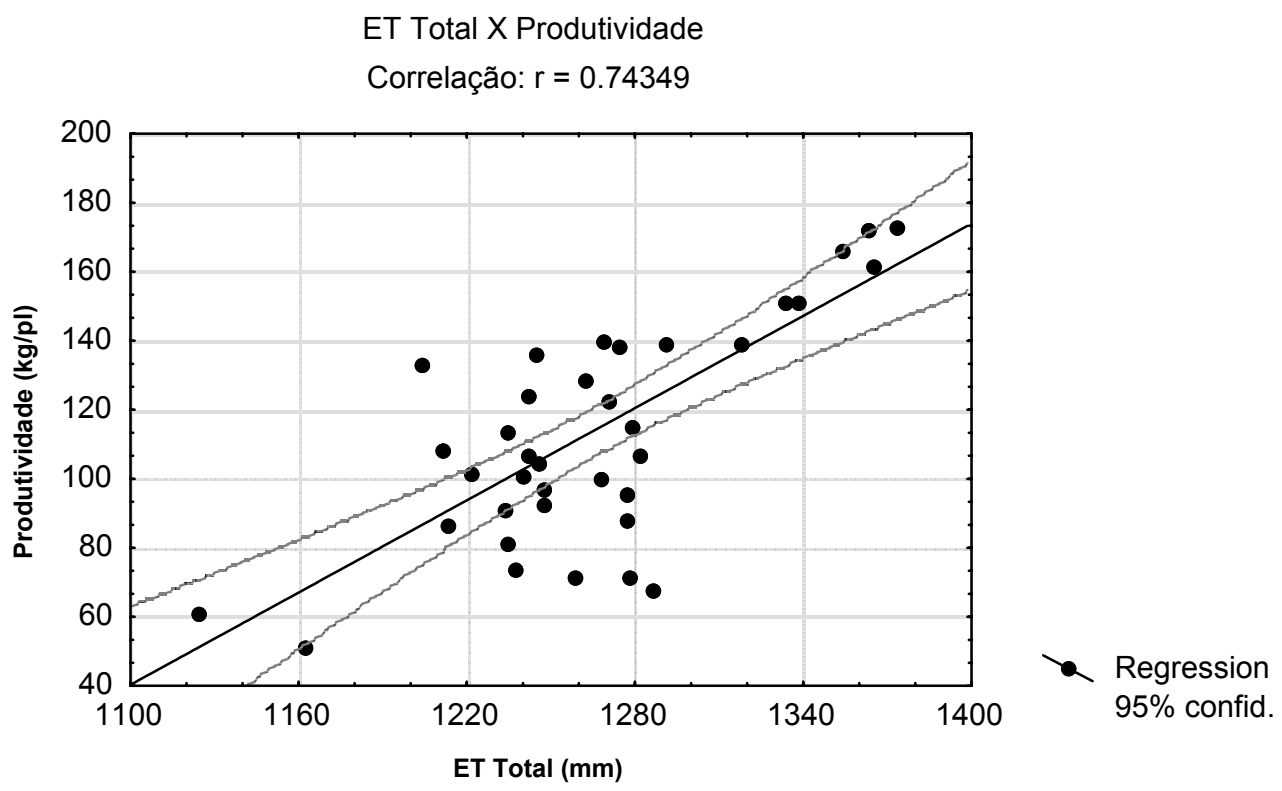

Gráfico 7 - Correlação entre resultados de ET e produtividade por planta ao nível de $5 \%$ de probabilidade. 
A Tabela 8 apresenta os resultados de ETc (evapotranspiração medida), ECA (evaporação medida no Tanque Classe A) e a relação ETc/ECA para os 14 períodos moniotrados. A preferência pela expressão dos resultados de consumo de água pela cultura citros pela relação entre esta ETc e a evaporação medida pelo Tanque Classe $A(E C A)$ foi em função da maior facilidade de obtenção dos dados de ECA quando comparada com as estimativas de ET pelos métodos de Penman (1948) ou de Thornthwaite \& Mather (1955) que envolvem a medida de índices climatológicos não tão simples de medida.

Verifica-se que, para as condições climáticas ocorridas durante o ciclo monitorado (2001-2002), em solo de características arenosas como o Latossolo Vermelho Amarelo estudado os valores da relação entre a ETc medida e a ECA são bastante diferentes daqueles obtidos em estudos realizados nos EUA, tanto em pomares do Arizona como em pomares da Flórida. Nos meses de maior demanda hídrica motivada pelo estágio fenológico da cultura de maior necessidade, a relação é superior a 1 (P7, P8 e P10), enquanto que nos trabalhos de Hilgeman \& Van Horn (1954), Reeve \& Furr (1941), Kalma (1972) e Van Bavel et al. (1966) a relação não ultrapassava 0,66, sendo o menor valor encontrado de 0,25 para os meses de menor necessidade hídrica.

Tabela 8. Relação $E T_{d} / E C A$ para todos os períodos monitorados em $\mathrm{mm} \mathrm{dia}^{-1}$.

\begin{tabular}{cccc}
\hline Período & $\begin{array}{c}\text { ETc } \\
\left(\mathrm{mm} \mathrm{dia}^{-1}\right)\end{array}$ & $\begin{array}{c}\text { ECA } \\
\left(\mathrm{mm} \mathrm{dia}^{-1}\right)\end{array}$ & ETc/ECA \\
\hline P1 & 1,8 & 3,9 & 0,5 \\
P2 & 1,6 & 4,6 & 0,3 \\
P3 & 4,2 & 4,8 & 0,9 \\
P4 & 2,1 & 6,4 & 0,3 \\
P5 & 3,5 & 6,4 & 0,5 \\
P6 & 4,0 & 5,6 & 0,7 \\
P7 & 7,5 & 5,1 & 1,5 \\
P8 & 8,3 & 5,6 & 1,5 \\
P9 & 3,7 & 5,9 & 0,6 \\
P10 & 6,7 & 5,5 & 1,2 \\
P11 & 2,5 & 5,0 & 0,5 \\
P12 & 1,8 & 3,5 & 0,5 \\
P13 & 2,5 & 2,9 & 0,9 \\
P14 & 0,4 & 3,2 & 0,1 \\
\hline
\end{tabular}




\subsection{Experimento de extração de água por uma planta de citros}

Os estudos realizados com distribuição de raízes em citros são bastante variados e tem apresentado resultados nem sempre concordantes. As dificuldades de extrapolação dos resultados destes estudos a partir de amostras de solo têm sido grandes e sucitado discussões. As novas técnicas de tratamento de imagens obtidas a partir de fotografias tem contribuído para a melhoria destes trabalhos de descrição espacial da distribuição radicular em citros. Gardner (1964) relacionou a distribuição radicular de sorgo medida com a estimada por modelo matemático, neste trabalho o autor já comentava a dificuldade de obter-se uma boa estimativa da distribuição radicular a partir de amostras de solo.

Os trabalhos realizados por Montenegro (1960) e Moreira (1983), com diferentes tipos de laranjeiras e sobre diferentes porta-enxertos são os mais detalhados. Cintra (1997) utilizando a técnica de tratamento de imagens obtidas por fotografia, em solo do ecossitema dos Tabuleiros Costeiros contribuiu também para o melhor entendimento da formação de raízes para a cultura de citros e sua distribuição espacial em relação à copa, embora seja específico para perfis com características especiais.

As Tabelas 9, 10, 11 e 12 apresentam os resultados do balanço hídrico realizado para os dois períodos escolhidos e nas duas direções avaliadas. As Tabelas 9 e 10 correspondem aos balanços realizados em período úmido. Nestes balanços observa-se que a contribuição é maior nas camadas superficiais até a profundidade de $0,60 \mathrm{~m}$, sendo maior de 0 a 0,40 m. Não é observada nenhuma ascensão capilar em função da grande precipitação pluviométrica ocorrida neste período. A ocorrência de drenagem profunda é grande pelo mesmo motivo.

Comparando-se as Tabelas 9 e 10 verifica-se não haver diferenças nas duas direções avaliadas. Esperava-se que, em função da maior liberdade de crescimento das raízes em direção à entrelinha e também devido a possível sobreposição de raízes em direção à linha, ocorresse maiores diferenças de 
comportamento, fato não verificado. Devido ao cultivo de grama-seda nas entrelinhas a contribuição das camadas superficiais é também acentuada neste balanço.

Tabela 9. Balanço hídrico $(\mathrm{mm})$ por camada e por distância do troco para o período úmido (37 dias) em direção à linha.

\begin{tabular}{|c|c|c|c|c|c|c|c|}
\hline Distância & Profundidade & $\begin{array}{l}\text { Var. } \\
\text { Arm. }\end{array}$ & Drenagem & Asc. & Precipitação & ET & ET/dia \\
\hline \multirow{5}{*}{$0,4 \mathrm{~m}$} & $0,0-0,4 \mathrm{~m}$ & 29,70 & 100,00 & 0,00 & 153,34 & 83,04 & 2,24 \\
\hline & $0,4-0,6 \mathrm{~m}$ & 23,70 & 75,00 & 0,00 & 153,34 & 48,70 & 1,32 \\
\hline & $0,6-0,8 \mathrm{~m}$ & 22,61 & 70,00 & 0,00 & 153,34 & 27,61 & 0,75 \\
\hline & $0,8-1,0 \mathrm{~m}$ & 18,00 & 62,00 & 0,00 & 153,34 & 26,00 & 0,70 \\
\hline & $1,0-1,1 \mathrm{~m}$ & 15,00 & 55,00 & 0,00 & 153,34 & 22,00 & 0,59 \\
\hline \multirow[t]{5}{*}{$0,8 \mathrm{~m}$} & $0,0-0,4 \mathrm{~m}$ & 35,78 & 104,00 & 0,00 & 153,34 & 85,12 & 2,30 \\
\hline & $0,4-0,6 \mathrm{~m}$ & 23,02 & 80,00 & 0,00 & 153,34 & 47,02 & 1,27 \\
\hline & $0,6-0,8 \mathrm{~m}$ & 24,26 & 76,00 & 0,00 & 153,34 & 28,26 & 0,76 \\
\hline & $0,8-1,0 \mathrm{~m}$ & 18,00 & 64,00 & 0,00 & 153,34 & 30,00 & 0,81 \\
\hline & $1,0-1,1 \mathrm{~m}$ & 15,00 & 56,00 & 0,00 & 153,34 & 23,00 & 0,62 \\
\hline \multirow[t]{5}{*}{$1,2 \mathrm{~m}$} & $0,0-0,4 \mathrm{~m}$ & 28,02 & 102,00 & 0,00 & 153,34 & 79,36 & 2,14 \\
\hline & $0,4-0,6 \mathrm{~m}$ & 28,76 & 80,00 & 0,00 & 153,34 & 50,76 & 1,37 \\
\hline & $0,6-0,8 \mathrm{~m}$ & 33,45 & 76,00 & 0,00 & 153,34 & 37,45 & 1,01 \\
\hline & $0,8-1,0 \mathrm{~m}$ & 18,00 & 61,00 & 0,00 & 153,34 & 33,00 & 0,89 \\
\hline & $1,0-1,1 \mathrm{~m}$ & 15,00 & 51,00 & 0,00 & 153,34 & 25,00 & 0,68 \\
\hline \multirow[t]{5}{*}{$1,6 \mathrm{~m}$} & $0,0-0,4 \mathrm{~m}$ & 28,13 & 105,00 & 0,00 & 153,34 & 76,47 & 2,07 \\
\hline & $0,4-0,6 \mathrm{~m}$ & 30,44 & 84,00 & 0,00 & 153,34 & 51,44 & 1,39 \\
\hline & $0,6-0,8 \mathrm{~m}$ & 30,88 & 79,00 & 0,00 & 153,34 & 35,88 & 0,97 \\
\hline & $0,8-1,0 \mathrm{~m}$ & 18,00 & 63,00 & 0,00 & 153,34 & 34,00 & 0,92 \\
\hline & $1,0-1,1 \mathrm{~m}$ & 15,00 & 56,00 & 0,00 & 153,34 & 22,00 & 0,59 \\
\hline \multirow[t]{5}{*}{$2,0 \mathrm{~m}$} & $0,0-0,4 \mathrm{~m}$ & 20,59 & 106,00 & 0,00 & 153,34 & 67,93 & 1,84 \\
\hline & $0,4-0,6 \mathrm{~m}$ & 23,47 & 83,00 & 0,00 & 153,34 & 46,47 & 1,26 \\
\hline & $0,6-0,8 \mathrm{~m}$ & 29,63 & 79,00 & 0,00 & 153,34 & 33,63 & 0,91 \\
\hline & $0,8-1,0 \mathrm{~m}$ & 18,00 & 64,00 & 0,00 & 153,34 & 33,00 & 0,89 \\
\hline & $1,0-1,1 \mathrm{~m}$ & 15,00 & 57,00 & 0,00 & 153,34 & 22,00 & 0,59 \\
\hline
\end{tabular}

Outra constatação importante é que devido a grande contribuição das chuvas ocorridas no período, existem também fortes indícios de que a evaporação do solo esteja contribuindo bastante para estes resultados pois não foi distinguida esta da evapotranspiração medida.

Neste período, embora com pequenas diferenças, em média $70 \%$ da água evapotranspirada é proveniente das camadas superficiais de 0 à 0,60 $\mathrm{m}$. Os $30 \%$ restantes são divididos entre as outras três camadas, com quase $20 \%$ sendo proveniente da camada de 0,0-0,80 m. 
Tabela 10. Balanço hídrico $(\mathrm{mm})$ por camada e por distância do troco para o período úmido (37 dias) em direção à entrelinha.

\begin{tabular}{|c|c|c|c|c|c|c|c|}
\hline Distância & Profundidade & $\begin{array}{l}\text { Var. } \\
\text { Arm. }\end{array}$ & Drenagem & Asc. & Precipitação & ET & ET/dia \\
\hline \multirow[t]{5}{*}{$0,4 \mathrm{~m}$} & $0,0-0,4 \mathrm{~m}$ & 32,00 & 102,00 & 0,00 & 153,34 & 83,34 & 2,25 \\
\hline & $0,4-0,6 \mathrm{~m}$ & 24,44 & 75,00 & 0,00 & 153,34 & 51,44 & 1,39 \\
\hline & $0,6-0,8 \mathrm{~m}$ & 34,36 & 70,00 & 0,00 & 153,34 & 39,36 & 1,06 \\
\hline & $0,8-1,0 \mathrm{~m}$ & 18,00 & 62,00 & 0,00 & 153,34 & 26,00 & 0,70 \\
\hline & $1,0-1,1 \mathrm{~m}$ & 15,00 & 55,00 & 0,00 & 153,34 & 22,00 & 0,59 \\
\hline \multirow{5}{*}{$0,8 \mathrm{~m}$} & $0,0-0,4 \mathrm{~m}$ & 30,00 & 105,00 & 0,00 & 153,34 & 78,34 & 2,12 \\
\hline & $0,4-0,6 \mathrm{~m}$ & 10,78 & 80,00 & 0,00 & 153,34 & 35,78 & 0,97 \\
\hline & $0,6-0,8 \mathrm{~m}$ & 22,03 & 70,00 & 0,00 & 153,34 & 32,03 & 0,87 \\
\hline & $0,8-1,0 \mathrm{~m}$ & 18,00 & 62,00 & 0,00 & 153,34 & 26,00 & 0,70 \\
\hline & $1,0-1,1 \mathrm{~m}$ & 15,00 & 55,00 & 0,00 & 153,34 & 22,00 & 0,59 \\
\hline \multirow[t]{5}{*}{$1,2 \mathrm{~m}$} & $0,0-0,4 \mathrm{~m}$ & 31,00 & 103,00 & 0,00 & 153,34 & 81,34 & 2,20 \\
\hline & $0,4-0,6 \mathrm{~m}$ & 25,04 & 80,00 & 0,00 & 153,34 & 48,04 & 1,30 \\
\hline & $0,6-0,8 \mathrm{~m}$ & 29,92 & 76,00 & 0,00 & 153,34 & 33,92 & 0,92 \\
\hline & $0,8-1,0 \mathrm{~m}$ & 18,00 & 62,00 & 0,00 & 153,34 & 32,00 & 0,86 \\
\hline & $1,0-1,1 \mathrm{~m}$ & 15,00 & 55,00 & 0,00 & 153,34 & 22,00 & 0,59 \\
\hline \multirow[t]{5}{*}{$1,6 \mathrm{~m}$} & $0,0-0,4 \mathrm{~m}$ & 33,00 & 101,00 & 0,00 & 153,34 & 85,34 & 2,31 \\
\hline & $0,4-0,6 \mathrm{~m}$ & 22,70 & 84,00 & 0,00 & 153,34 & 39,70 & 1,07 \\
\hline & $0,6-0,8 \mathrm{~m}$ & 23,14 & 75,00 & 0,00 & 153,34 & 32,14 & 0,87 \\
\hline & $0,8-1,0 \mathrm{~m}$ & 18,00 & 62,00 & 0,00 & 153,34 & 31,00 & 0,84 \\
\hline & $1,0-1,1 \mathrm{~m}$ & 15,00 & 55,00 & 0,00 & 153,34 & 22,00 & 0,59 \\
\hline \multirow[t]{5}{*}{$2,0 \mathrm{~m}$} & $0,0-0,4 \mathrm{~m}$ & 30,00 & 102,00 & 0,00 & 153,34 & 81,34 & 2,20 \\
\hline & $0,4-0,6 \mathrm{~m}$ & 22,00 & 83,00 & 0,00 & 153,34 & 41,00 & 1,11 \\
\hline & $0,6-0,8 \mathrm{~m}$ & 21,00 & 79,00 & 0,00 & 153,34 & 25,00 & 0,68 \\
\hline & $0,8-1,0 \mathrm{~m}$ & 18,00 & 75,00 & 0,00 & 153,34 & 22,00 & 0,59 \\
\hline & $1,0-1,1 \mathrm{~m}$ & 15,00 & 55,00 & 0,00 & 153,34 & 35,00 & 0,95 \\
\hline
\end{tabular}

As Tabelas 11 e 12 são referentes ao período considerado seco e apresentaram resultados diferentes em relação ao período úmido. A ocorrência de ascensão capilar é verificada, assinalando para possível pequena contribuição do lençol freático em períodos de menor precipitação nesta classe de solo. Observa-se agora, maior contribuição da camada de 0,40 a 0,60 m no total do balanço hídrico acenando para a ocorrência de maior volume de raízes nesta camada de solo como já observado nos trabalhos de Montenegro (1960), Moreira (1983) e Nooling (1992). Para Ford (1954) a camada de maior volume de raízes foi de 0,75 a 1,50 m o que não foi observado neste estudo. Durante este período mais seco, ocorre uma contribuição maior das camadas de 0 à 0,60 que contribuem com 70 à $80 \%$ do total de água evapotranspirada. $A$ camada de 1,00 - 1,10 m tem contribuição bem menor do aquela verificada 
durante o período úmido. Enquanto que no período úmido esta camada contribui com $10 \%$ do total, no período seco esta contribuição reduz-se para 3 $4 \%$ em média, sendo que em algumas posições nem houve contribuição.

A adoção de $1,10 \mathrm{~m}$ como profundidade limite para o cálculo do balanço, sugerida pelos estudos realizados por Montenegro (1960), Kolesnikov (1971), Jones \& Embleton (1973), Moreira (1983) e Nooling (1992) foi adequada e pode estimar com segurança o consumo hídrico da cultura. As sugestões de 2 m para o raio máximo de crescimento em relação ao tronco encontradas em Montenegro (1960), Kolesnikov (1971) e Moreira (1983) também foram corroboradas pelos resultados deste estudo.

Os tensiômetros instalados em direção à entrelinha durante o período seco mediram potenciais matricos que resultaram em consumo de água superior na camada que vai de 0 à $0,60 \mathrm{~m}$ com maior consumo ocorrendo na camada de 0,40 à $0,60 \mathrm{~m}$. Em relação à distancia do tronco não foi observada diferenças marcantes, somente na distância de 2,00 m houve sensível superioridade da camada de 0,40 à $0,60 \mathrm{~m}$, diferente do encontrado nas outras distâncias avaliadas. Em função da entrelinha ser cultivada com grama, a contribuição da camada de 0 à $0,40 \mathrm{~m}$ pode sofrer influência das raízes superficiais desta planta.

Neste último período monitorado verifica-se a ocorrência de pequena ascensão capilar, em média de $3 \mathrm{~mm}$ durante todo o período de 37 dias, o que não foi observado durante o período úmido. 
Tabela 11. Balanço hídrico $(\mathrm{mm})$ por camada e por distância do troco para o período seco (37 dias) em direção à linha.

\begin{tabular}{cccccccc}
\hline \multirow{2}{*}{ Distância } & Profundidade & Arm. & Drenagem & Asc. & Precipitação & ET & ET/dia \\
\hline \multirow{2}{*}{$0,4 \mathrm{~m}$} & $0,0-0,4 \mathrm{~m}$ & $-21,00$ & 26,00 & 0,00 & 53,50 & 6,50 & 0,18 \\
& $0,4-0,6 \mathrm{~m}$ & $-15,00$ & 4,00 & 0,00 & 53,50 & 7,00 & 0,19 \\
& $0,6-0,8 \mathrm{~m}$ & $-3,00$ & 1,00 & 0,00 & 53,50 & 0,00 & 0,00 \\
& $0,8-1,0 \mathrm{~m}$ & $-2,00$ & 1,00 & 3,00 & 53,50 & 1,00 & 0,03 \\
\multirow{3}{*}{$0,8 \mathrm{~m}$} & $1,0-1,1 \mathrm{~m}$ & $-2,00$ & 2,00 & 3,10 & 53,50 & 0,10 & 0,00 \\
& $0,0-0,4 \mathrm{~m}$ & $-20,00$ & 25,00 & 0,00 & 53,50 & 8,50 & 0,23 \\
& $0,4-0,6 \mathrm{~m}$ & $-10,00$ & 7,00 & 0,00 & 53,50 & 8,00 & 0,22 \\
& $0,6-0,8 \mathrm{~m}$ & $-2,00$ & 6,00 & 3,60 & 53,50 & 2,60 & 0,07 \\
& $0,8-1,0 \mathrm{~m}$ & $-2,10$ & 5,00 & 3,80 & 53,50 & 2,70 & 0,07 \\
\multirow{3}{*}{$1,2 \mathrm{~m}$} & $1,0-1,1 \mathrm{~m}$ & $-1,80$ & 5,00 & 3,60 & 53,50 & 1,80 & 0,05 \\
& $0,0-0,4 \mathrm{~m}$ & $-19,00$ & 25,00 & 1,00 & 53,50 & 9,50 & 0,26 \\
& $0,4-0,6 \mathrm{~m}$ & $-9,00$ & 5,00 & 3,00 & 53,50 & 14,00 & 0,38 \\
& $0,6-0,8 \mathrm{~m}$ & $-4,00$ & 4,00 & 3,20 & 53,50 & 0,20 & 0,01 \\
& $0,8-1,0 \mathrm{~m}$ & $-5,20$ & 1,00 & 3,10 & 53,50 & 0,90 & 0,02 \\
\multirow{3}{*}{$\mathrm{m} \mathrm{m}$} & $1,0-1,1 \mathrm{~m}$ & $-3,00$ & 0,00 & 2,50 & 53,50 & 0,50 & 0,01 \\
& $0,0-0,4 \mathrm{~m}$ & $-23,00$ & 25,00 & 0,00 & 53,50 & 5,50 & 0,15 \\
& $0,4-0,6 \mathrm{~m}$ & $-5,00$ & 6,00 & 0,00 & 53,50 & 14,00 & 0,38 \\
& $0,6-0,8 \mathrm{~m}$ & $-3,50$ & 2,00 & 1,70 & 53,50 & 2,20 & 0,06 \\
& $0,8-1,0 \mathrm{~m}$ & $-1,80$ & 3,80 & 3,80 & 53,50 & 0,20 & 0,01 \\
\multirow{3}{*}{$2,0 \mathrm{~m}$} & $1,0-1,1 \mathrm{~m}$ & $-5,00$ & 2,60 & 3,80 & 53,50 & 0,00 & 0,00 \\
& $0,0-0,4 \mathrm{~m}$ & $-22,00$ & 25,00 & 0,00 & 53,50 & 6,50 & 0,18 \\
& $0,4-0,6 \mathrm{~m}$ & $-14,00$ & 5,00 & 1,20 & 53,50 & 7,20 & 0,19 \\
& $0,6-0,8 \mathrm{~m}$ & $-5,00$ & 1,00 & 1,90 & 53,50 & 0,90 & 0,02 \\
& $0,8-1,0 \mathrm{~m}$ & $-1,00$ & 2,00 & 2,70 & 53,50 & 0,70 & 0,02 \\
& $1,0-1,1 \mathrm{~m}$ & $-1,00$ & 3,00 & 2,80 & 53,50 & 0,80 & 0,02 \\
\hline
\end{tabular}

A ET total dos dois períodos foi coerente com a ET calculada para esta planta pelo experimento 1. No primeiro experimento verificou-se um consumo de cerca de $110 \mathrm{~mm}$ durante o período úmido e $40 \mathrm{~mm}$ no período seco, bastante próximo dos resultados obtidos durante o experimento 2 . 
Tabela 12. Balanço hídrico $(\mathrm{mm})$ por camada e por distância do troco para o período seco (37 dias) em direção à entrelinha.

\begin{tabular}{cccccccc}
\hline \multirow{2}{*}{ Distância } & Profundidade & Arm. & Drenagem & Asc. & Precipitação & ET & ET/dia \\
\hline \multirow{2}{*}{$0,4 \mathrm{~m}$} & $0,0-0,4 \mathrm{~m}$ & $-20,00$ & 25,00 & 0,00 & 53,50 & 8,50 & 0,23 \\
& $0,4-0,6 \mathrm{~m}$ & $-7,00$ & 9,00 & 0,00 & 53,50 & 9,00 & 0,24 \\
& $0,6-0,8 \mathrm{~m}$ & $-1,00$ & 3,00 & 0,00 & 53,50 & 5,00 & 0,14 \\
& $0,8-1,0 \mathrm{~m}$ & $-2,00$ & 1,00 & 4,00 & 53,50 & 4,00 & 0,11 \\
\multirow{3}{*}{$0,8 \mathrm{~m}$} & $1,0-1,1 \mathrm{~m}$ & 2,00 & 1,00 & 3,00 & 53,50 & 1,00 & 0,03 \\
& $0,0-0,4 \mathrm{~m}$ & $-21,00$ & 25,00 & 0,00 & 53,50 & 7,50 & 0,20 \\
& $0,4-0,6 \mathrm{~m}$ & $-8,00$ & 10,00 & 0,00 & 53,50 & 7,00 & 0,19 \\
& $0,6-0,8 \mathrm{~m}$ & $-4,00$ & 5,00 & 4,00 & 53,50 & 5,00 & 0,14 \\
& $0,8-1,0 \mathrm{~m}$ & 1,00 & 5,00 & 4,00 & 53,50 & 1,00 & 0,03 \\
\multirow{3}{*}{$1,2 \mathrm{~m}$} & $1,0-1,1 \mathrm{~m}$ & 1,00 & 5,00 & 4,00 & 53,50 & 1,00 & 0,03 \\
& $0,0-0,4 \mathrm{~m}$ & $-23,00$ & 22,00 & 1,00 & 53,50 & 8,50 & 0,23 \\
& $0,4-0,6 \mathrm{~m}$ & $-9,00$ & 10,00 & 4,00 & 53,50 & 6,00 & 0,16 \\
& $0,6-0,8 \mathrm{~m}$ & $-3,00$ & 4,00 & 3,00 & 53,50 & 2,00 & 0,05 \\
& $0,8-1,0 \mathrm{~m}$ & $-1,50$ & 1,00 & 3,00 & 53,50 & 1,50 & 0,04 \\
\multirow{3}{*}{$\mathrm{m} \mathrm{m}$} & $1,0-1,1 \mathrm{~m}$ & 0,50 & 0,00 & 1,50 & 53,50 & 0,00 & 0,00 \\
& $0,0-0,4 \mathrm{~m}$ & $-24,00$ & 25,00 & 0,00 & 53,50 & 4,50 & 0,12 \\
& $0,4-0,6 \mathrm{~m}$ & $-8,50$ & 11,00 & 0,00 & 53,50 & 5,50 & 0,15 \\
& $0,6-0,8 \mathrm{~m}$ & $-5,00$ & 5,00 & 2,00 & 53,50 & 3,00 & 0,08 \\
& $0,8-1,0 \mathrm{~m}$ & $-4,00$ & 3,00 & 3,00 & 53,50 & 1,00 & 0,03 \\
\multirow{3}{*}{$2,0 \mathrm{~m}$} & $1,0-1,1 \mathrm{~m}$ & $-1,00$ & 3,00 & 3,00 & 53,50 & 1,00 & 0,03 \\
& $0,0-0,4 \mathrm{~m}$ & $-22,00$ & 24,00 & 0,00 & 53,50 & 7,50 & 0,20 \\
& $0,4-0,6 \mathrm{~m}$ & $-3,10$ & 11,00 & 1,00 & 53,50 & 10,90 & 0,29 \\
& $0,6-0,8 \mathrm{~m}$ & $-2,00$ & 3,00 & 2,00 & 53,50 & 7,00 & 0,19 \\
& $0,8-1,0 \mathrm{~m}$ & $-1,40$ & 1,00 & 3,00 & 53,50 & 1,60 & 0,04 \\
& $1,0-1,1 \mathrm{~m}$ & $-2,00$ & 0,00 & 4,00 & 53,50 & 0,00 & 0,00 \\
\hline
\end{tabular}

Em adição ao balanço por camadas realizado a partir do monitoramento dos potenciais mátricos em diferentes profundidades $\mathrm{e}$ distâncias do tronco, calculou-se a umidade média (pela curva característica da água no solo) para os 37 dias nos dois períodos monitorados. Com estas médias obtidas foram identificados o maior e o menor valor de umidade para cada período. A partir deste intervalo obtido dividimo-lo em três faixas de umidade identificando com cores cada intervalo. O resultado está mostrado nas Figuras 12 e 13. Esta forma de expressão dos resultados reflete os resultados observados pelo balanço por camadas e tem o objetivo de ilustrar as conclusões anteriormente obtidas. 


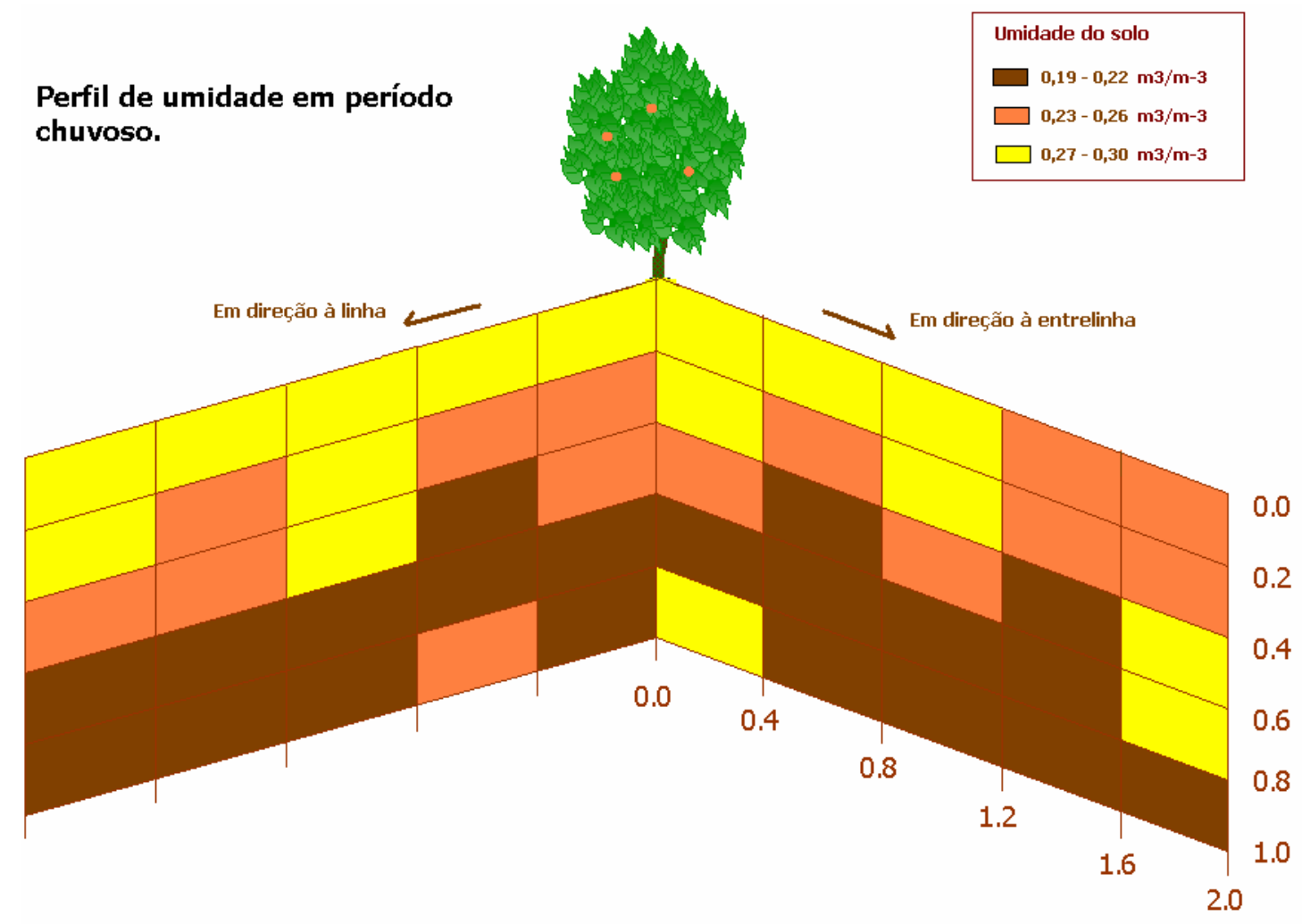

Figura 12 - Perfil de umidade para as várias distâncias do tronco, em direção à linha e em direção à entrelinha durante período úmido.

Durante o período úmido (Figura 12) verifica-se maior umidade nas camadas superficiais do solo, o que corrobora a desconfiança da possível significativa contribuição da evaporação do solo nos resultados de consumo de água. Neste período observa-se também maior extração (menor umidade média) em profundidade, nas camadas a partir de 0,60 $\mathrm{m}$ até 1,0 $\mathrm{m}$. A distância de 0,40 à $0,80 \mathrm{~m}$ do tronco mantém a menor umidade média, sugerindo ser esta a distância mais significativa no que diz respeito ao volume de raízes e conseqüentemente na extração de água. Concordando com os resultados apresentados no balanço hídrico por camadas, não foram observadas diferenças significativas nos dois sentidos avaliados (linha e entrelinha). 


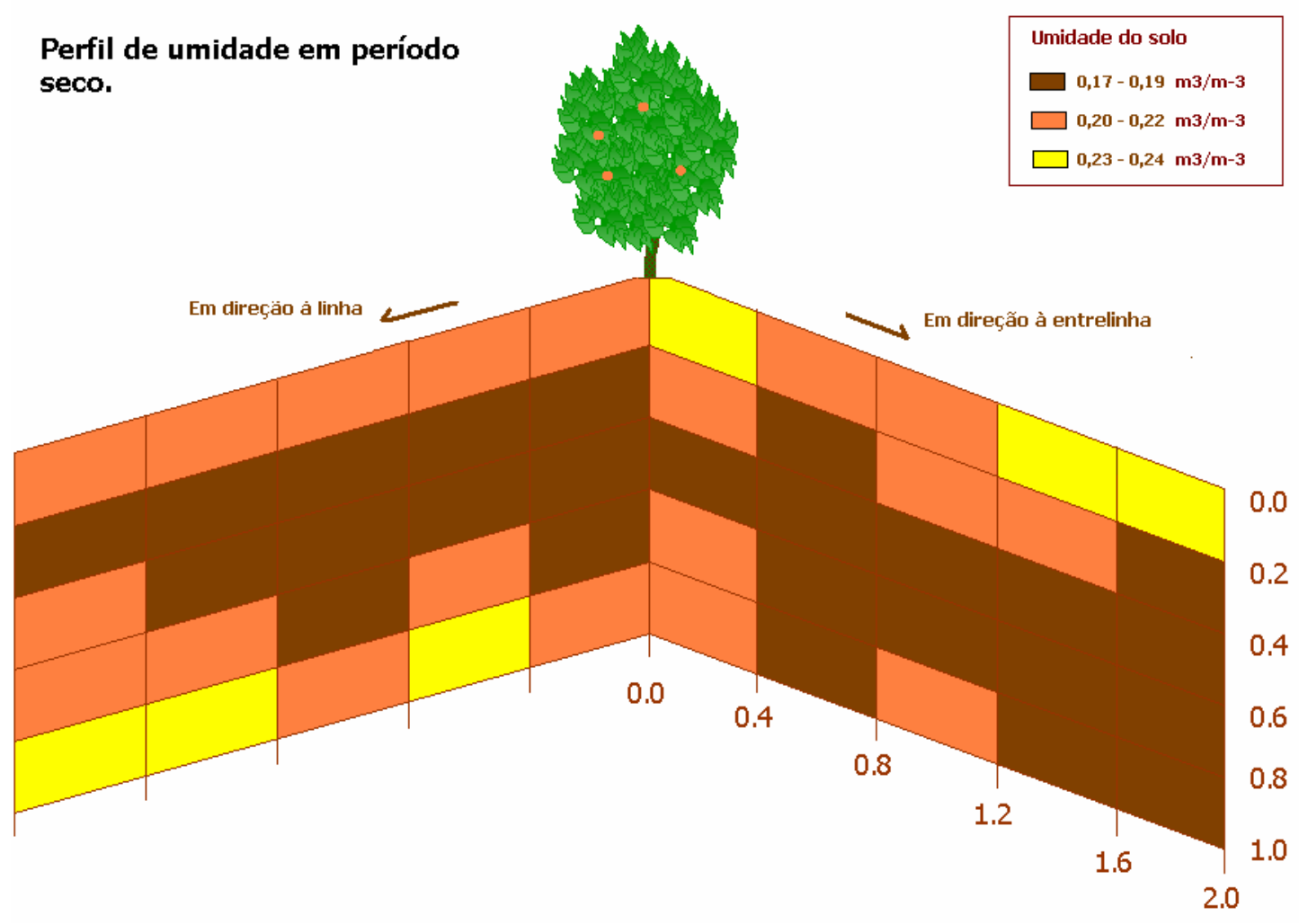

Figura 13 - Perfil de umidade para as várias distâncias do tronco, em direção à linha e em direção à entrelinha durante período seco.

No período considerado seco (Figura 13) evidencia-se a maior contribuição da camada de 0,20 à $0,40 \mathrm{~m}$, com resultados mais consistentes no sentido da linha. No sentido da entrelinha a menor umidade média foi obtida nas camadas de 0,20 à $0,60 \mathrm{~m}$, havendo boa contribuição em maior profundidade $(0,60$ à $1,00 \mathrm{~m})$ das distâncias de 0,40 à 2,00 $\mathrm{m}$.

Este artifício ilustrativo de análise, monitorando-se a umidade média de cada camada de solo e em várias distâncias do tronco da planta de citros parece ser bastante interessante pois dá uma idéia espacial dos locais onde a ação radicular mantém o solo menos úmido em função de sua extração maior de água. Para estudos de irrigação localizada por microaspersores ou gotejadores, este tipo de apresentação de resultados pode ter importante papel na tomada de decisão quanto à colocação dos aparelhos. No interesse de uma maior distinção destas informações bastaria a instalação de tensiômetros num 
maior número de profundidades e distâncias do tronco ou caule da cultura de interesse.

\subsection{Outras considerações}

A idéia de realizar um monitoramento do consumo hídrico de uma cultura a partir de medidas de entradas e saídas de água de uma camada controle de solo caracterizando o comportamento de determinada classe de solos, antes de tornar-se apenas uma caracterização, é fundamental para o completo conhecimento da cultura em estudo bem como para futuros projetos de irrigação.

Previsões mais catastróficas feitas por alguns ambientalistas nos alertam que dentro de 25 anos algumas regiões do globo terrestre podem manifestar escassez de água. Não sendo tão drástico podemos afirmar que dentro de 50 anos alguns países estarão sofrendo de falta de água, muito provavelmente alguns de nós estaremos vivenciando esta realidade.

Somando-se a importância econômica do consumo de água para a cultura de citros, sob o ponto de vista de um projeto de custos de irrigação, a importância ambiental futura do insumo água, pesquisas que envolvam estes dimensionamentos tendem a tornar-se cada vez mais preponderantes para a boa condução de um empreendimento agrícola.

Em função do exposto, este trabalho tem a intenção de contribuir para o entendimento do consumo hídrico da cultura de citros conduzida em classe Latossolo Vermelho-Amarelo e permitir que estes resultados possam servir de subsídio para o econômico uso da água, tanto agronomicamente quanto ecologicamente. 


\section{CONCLUSÕES}

Em face dos resultados obtidos e baseado nas discussões apresentadas, pode-se concluir que:

1. o balanço hídrico no solo é uma metodologia que estima com boa segurança o consumo de água numa comunidade de plantas;

2. a camada de 0,40 à $0,60 \mathrm{~m}$ de profundidade deve ser considerada como aquela em que a cultura de citros apresenta maior volume de raízes;

3. o consumo de água da cultura de citros, ao longo do ciclo, é variável à medida que muda seu estágio fenológico e sugestões de $\mathrm{kc}$ devem envolver sempre a ET da cultura e não somente dados climatológicos;

4. em futuros projetos de irrigação por gotejadores (irrigação localizada) para a cultura de citros, a distância de $0,40 \mathrm{~m}$ do tronco deve ser adotada para a obtenção de melhor eficiência;

5. a ET variou de 0,4 à $8,3 \mathrm{~mm} \mathrm{dia}^{-1}$ para os períodos de menor $\mathrm{e}$ maior necessidade hídrica, respectivamente;

6. a razão $E T c / E C A$ variou de 0,3 à 1,5 para os mesmos períodos acima citados;

7. a E.U.A. variou de 1,57 à $4,52 \mathrm{~kg} \cdot \mathrm{m}^{-3}$ para a menos e a mais eficiente planta avaliada, respectivamente. 


\section{REFERÊNCIAS BIBLIOGRÁFICAS}

ALLEN, R.G.; SMITH, M.; PEREIRA, L.S.; PRUIT, W.O. Proposed revision to the FAO procedure for estimating crop water requirements. In: SYMPOSIUM ON IRRIGATION OF HORTICULTURAL CROPS, 2., New York, 1997. Proceedings. New York, 1997.v.1, p.17-33.

ANDREATTA, J.A. Determinação da razão entre a evapotranspiração máxima de dois cultivares de milho (Zea mays L.) e a evapotranspiração potencial. Botucatu, 1990. 94 p. Dissertação (Mestrado) - Faculdade de Ciências Agrárias, Universidade Estadual Paulista "Júlio de Mesquita Filho".

ANGELOCCI, L.R. Necessidade hídrica de frutíferas. In: SEMINÁRIO SOBRE ÁGUA NA PRODUÇÃO DE FRUTíFERAS, Pelotas, 2000. Pelotas: Embrapa Clima Temperado, 2000. p.6-7. (Embrapa. Clima Temperado. Documentos $68)$.

BANTON, O. Field and laboratory determined hydraulic conductivities considering anisotropy and core surface area. Soil Science Society of America Journal, v.57, p.10-15, 1993.

BANZATTO, D.A.; KRONKA, S.N. Experimentação agrícola. 3.ed. Jaboticabal: FUNEP, 1995. $247 \mathrm{p}$.

BEIGUELMAN, B. Curso prático de bioestatística. 3.ed. Ribeirão Preto: Sociedade Brasileira de Genética, 1994. 244p.

BEM MECHLIA, N.; CARROL, J.J. Agroclimatic modeling for the simulation of phenology, yield and quality of crop production. II. Citrus model implementation and verification. International Journal of Biometeorology, v.33, p.52-65, 1989. 
BLAKE, G. R.; HARTGE, K. H. Particle density. In: KLUTE, A. Methods of soil analysis. Madison: American Society of Agronomy, 1986. p.377-382.

BLACK, T.A.; GARDNER, W.R.; TANNER, C.B. Water storage and drainage under a row crop on a sandy soil. Agronomy Journal, v.62, p.48-51, 1970.

BRUNINI, O.; GROHMANN, F.; SANTOS, J.M. dos. Balanço hídrico em condições de campo para dois cultivares de arroz sob duas densidades de plantio. Revista Brasileira de Ciência do Solo, v.22, n.5, p.1-6, 1981.

BRUNINI, O. Consumo hídrico e parâmetros ecológicos da cultura do milho. In: SIMPÓSIO SOBRE MANEJO DE ÁGUA NA AGRICULTURA, Campinas, 1987. Anais Campinas: Fundação Cargill, 1987. p.93-122.

CAHOON, G.A.; STOLZY, L.H. Estimating root density in citrus orchard by neutron moderation method. Journal of the American Society for Horticultural Science, v.74, p.322-326, 1960.

CAMARGO, A. P. de. Balanço hídrico, florescimento e necessidade de água para o cafeeiro. In: SIMPÓSIO SOBRE MANEJO DE ÁGUA NA AGRICULTURA, Campinas, 1987. Anais Campinas: Fundação Cargill, 1987. p.53-90.

CARVALHO, L.A. Condutividade hidráulica do solo no campo: as simplificações do método do perfil instantâneo. Piracicaba, 2003. 89p. Dissertação (Mestrado) - Escola Superior de Agricultura "Luiz de Queiroz", Universidade de São Paulo.

CASTEL, J.R. Evapotranspiration of a drip-irrigated clementine citrus tree a weighing lysimeter Acta Horticulturae, n.449, p. 91-98, 1997.

CINTRA, F. L. D.; LIBARDI, P. L.; SAAD, A. M. Balanço hídrico na solo para porta-enxertos de citros em ecossistema de Tabuleiro Costeiro. Revista Brasileira de Engenharia Agrícola e Ambiental, v.4, n.1, p.23-28, 2000.

CRUCIANI, D.E. Balanço hídrico em solo cultivado com cana-de-açúcar.

Piracicaba: CENA, 1972. 32p. (Boletim Científico, 6)

DAVIES, F.S.; ALBRIGO, L.G. Cítricos Zaragoza: Ed. Acribia, 1994. 284 p. 
DOORENBOS, J.; KASSAN, A.H. Yield response to water. Rome: FAO, 1979. 193 p. (FAO. Irrigation Drainage Paper, 33).

DOOREMBOS, J.; PRUIT, W.O. Las necessidades de água de los cultivos. Roma: FAO, 1977. 144p. (FAO. Boletin Irrigación y Drenage, 24).

FARES, A.; ALVA, A.K. Estimation of citrus evapotranspiration by soil water mass balance Soil Science, v.164, p.302-310, 1999.

FIGUEIREDO, J.O. Variedades de copa de valor comercial. In: RODRIGUES, O.; VIEGAS, F.C.P.(Coord.). Citricultura brasileira. Campinas: Fundação Cargill, 1991. v.1, p.228-264.

FNP CONSULTORIA \& COMÉRCIO. Agrianual 2002: anuário de agricultura brasileira. São Paulo, 2001. p. 281-309: Citros.

FORD, H.W. Root distribution in relation to the water table. Proceedings of the American Society for Horticultural Science, v.67, p.30-33, 1954.

GARDNER, W. R. Soil properties and efficient water use: na overview. In: TAYLOR, H. W. (Ed.). Limitations to efficient water use in crop production. Madison: American Society of Agronomy, 1983. p.45-64.

GARWOOD, E.A.; WILLIAMS, T.E. Soil water use anf growth of a grass sward. Journal of Agricultural Science, v.68, p.281-292, 1967.

GEE, G. W.; BAUDER, J. W. Particle-size analysis. In: KLUTE, A. Methods of soil analysis. Madison: American Society of Agronomy, 1986. p.383-412.

GOMES, F.P. Curso de estatística experimental. 3.ed. Piracicaba: POTAFOS, 1987a. 162p.

GOMES, F.P. A estatística moderna na pesquisa agropecuária. 12.ed. Piracicaba: Nobel, 1987b. 467p.

GUANDIQUE, M.E.G.; LIBARDI, P.L. Balanço hídrico no solo e consumo de água para a cultura de Feijão (Phaseolus vulgaris L.) In: CONGRESSO BRASILEIRO DE AGROMETEOROLOGIA, 10., Piracicaba, 1997. Anais. Piracicaba: Sociedade Brasileira de Agrometeorologia; ESALQ, 1997. p.638640. 
HILGEMAN, R.H.; VAN HORN, C.W. Citrus growing in Arizona. Tucson: Arizona Agricultural Experimental Station, 1954. 35p. (Bulletin, 258).

HILLEL, D. Solo e água: fenômenos e princípios físicos. Porto Alegre: UFRGS, Departamento de Solos, 1970. 231p.

HOFFMAN, G.J.; OSTER, J.D.; ALVES, W.J. Evapotranspiration of mature orange trees under drip irrigation in an arid climate. Transactions of the ASAE, v.25, p.992-996, 1982.

HOLMES, J.W.; JENQUINSON, A.F. Technique for using the neutron moisture meter. Journal of Agricultural Engineering Research, v.3, p.199-201, 1959.

JONES, T.A. Skewnessand kurtosis as criteria of normality in observed frequency distributions. Journal of Sedimentary Petrology, v.39, n.4, p.1322-1627, 1969.

JONES, W. W.; EMBLETON, T. W. Soil manegement and cover crops. In: REUTHER, W. (Ed.). The citrus industry. Berkeley: University of California, 1973. v.3, cap. 4, p.98-121.

JONG VAN LIER, Q. Índices da disponibilidade de agua para as plantas. In: NOVAIS, R.F.de; ALVAREZ, V.H.; SCHAEFER, C.E.G.R. Tópicos em ciência do solo. Viçosa: Sociedade Brasileira de Ciência do Solo, 2000. , p.95-106.

KALMA, J.D.; STANHILL, G. The climate of an orange orchard: physical characteristics and microclimate relationships. Agricultural Meteorology, v.10, p.185-201, 1972.

KOLESNIKOV, V. The root system of fruit plant. Moscow: Mir Publ., 1971. 255p.

KOO, R.C.J. Evapotranspiration and soil moisture determination as guides to citrus irrigation. Alachua: Florida Agricultural Experimental Station, 1958. 232 p. (Annual Report). 
KOO, R.C.J.; HURNER, G.T. Irrigation requirements of citrus grown on Lakewood fine sand. Proceedings of the Florida State for Horticultural Society, v.82, p.69-72, 1969.

LAL, R. The effect of soil texture and density on the nêutron and density probe calibration for tropical soils. Soil Science, v.177, p.183-190, 1974.

LEVINE, D.M.; BERENSON, M.; STEPHAN, D. Estatística: teoria e aplicações. Trad. de T.C.P. de Souza. Rio de Janeiro:LTC, 2000. 812p.

LIBARDI, P. L. Dinâmica da água no solo. Piracicaba: O autor, 2000. 509p.

LIBARDI, P.L.; MANFRON, P.A.; MORAES, S.O.; TUON, R.L. Variabilidade da umidade gravimétrica de um solo hidromórfico. Revista Brasileira de Ciência do Solo, v.20, p.1-12, 1996.

LIBARDI, P.L.; REICHARDT, K.; NIELSEN, D.R.; BIGGAR, J.W. Simplified field methods for estimating the unsatured hydraulic conductivity in a cultivated field at different times. Soil Science Society of America Journal, v.44, p.36, 1980.

LOGSDON, S.D.; JAYNES, D.B. Spatial variability of hydraulic conductivity in a cultived field at different times. Soil Science Society of America Journal, v.60, p.703-709, 1996.

MIYAZAKI, T. Water flow in soils. New York: Marcel Dekker, 1993. cap.9, p.255-283: Heterogeneity of soils in fields.

MORAES, S.O. Heterogeneidade hidráulica de uma terra roxa estruturada. Piracicaba, 1991. 141p. Tese (Doutorado) - Escola Superior de Agricultura "Luiz de Queiroz" , Universidade de São Paulo.

MONTENEGRO, H.W.S. Contribuição ao estudo do sistema radicular das plantas cítricas. Piracicaba, 1960. 143 p. Tese (Cátedra) - Escola Superior de Agricultura "Luiz de Queiroz" , Universidade de São Paulo.

MONTENEGRO, H.W.S. Clima e solo. In: RODRIGUES, O.; VIEGAS, F.; POMPEU JR., J.; AMARO, A.A. (Ed.). Citricultura brasileira. Campinas: Fundação Cargill, 1991. v.1, p.225-239. 
MOREIRA, C.S. Estudo da distribuição do sistema radicular da Laranja Pêra (Citrus sinensis Osbeck) com diferentes manejos de solo. Piracicaba, 1983. 143 p. Dissertação (Mestrado) - Escola Superior de Agricultura "Luiz de Queiroz", Universidade de São Paulo.

MUALEN, Y. A new model for predicting the hydraulic conductivity of unsaturated porous media. Water Resources Research, v.12, n.3, p.513522, 1976.

MULLA, D.J.; McBRARNEY, A.B. Soil spatial variability. In: SUMNER, M.E. (Ed.). Handbook of soil science. New York: CRC Press, 2000. cap.9, p.321352.

NEL, D.J. Soil requirements for citrus growing. Nelspruit: Citrus and Subtropical Fruit Research Institute, 1984. 3p. (Citrus, B.4).

NIELSEN, D.R.; BIGGAR, J.W.; ERH, K.T. Spatial variability of field measured soil water properties. Hilgardia, v.42, n.7, p.215-259, 1973.

NYE, P.H.; TINKER, P.B. Solute movement in the soil-root system. Oxford: Blackwell Scientific, 1977. v.4, 342 p.

NOOLING, J.W. Citrus root growth and soil pest management practices. Gainesville: University of Florida, Entomology and Nematology Department, Florida Cooperative Extension Service, Institute of Food and Agricultural Sciences, 1992. 37p.

OLIVEIRA, J.B. de. Solos para citros. In: RODRIGUES, O.; VIEGAS, F.; POMPEU Jr., J.; AMARO, A.A. (Ed.). Citricultura brasileira. Campinas: Fundação Cargill, 1991. v. 1. p.196-227.

OLIVEIRA, J. B.; VAN DEN BERG, M. Aptidão agrícola das terras do Estado de São Paulo: quadrículas de Araras. II Memorial descritivo. Campinas: Instituto Agronômico, 1985. 60 p. (IAC. Boletim Técnico, 102).

OLIVEIRA, Z.P. de. Variabilidade espacial dos componentes do balanço hídrico em uma cultura de milho (Zea mays L.). Piracicaba, 1991. 73 p. Dissertação (Mestrado) - Escola Superior de Agricultura "Luiz de Queiroz", Universidade de São Paulo 
ORTOLANI, A.A.; CAMARGO, M.B.P. Influência dos fatores climáticos na produção. In: CASTRO, P.R.C.; FERREIRA, S.O.; YAMADA, T. Ecofisiologia da produção agrícola. Piracicaba: Associação Brasileira para Pesquisa da Potassa e do Fosfato, 1987. p.71-81.

ORTOLANI, A.A.; PEDRO JÚNIOR, M.J.; ALFONSI, R.R. Agroclimatologia e o cultivo de citros. In: RODRIGUES, O.; VIÉGAS, F.; POMPEU JR., J.; AMARO, A.A. (Ed.). Citricultura brasileira. 2.ed. Campinas: Fundação Cargill, 1991. v.1, 153-188.

PACE, C.A.M. Estudo da distribuição do sistema radicular de porta-enxertos cítricos em solos podzolizados. Rio de Janeiro, 1979. 81 p. Dissertação (Mestrado) - Universidade Federal Rural do Rio de Janeiro

PAIVA, A. Q.; SOUZA, L. S.; RIBEIRO, A. C.; COSTA, L. M. Disponibilidade de água em uma topossequência de solos de tabuleiro do Estado da Bahia e sua relação com indicadores do crescimento da laranjeira. Revista Brasileira de Ciência do Solo, v.22, n.3, p.367-377, 1998.

PENMAN, H.L. Natural evaporation from open water, bare soil and grass.

Proceedings of the Royal Society of London. Series A, v.193, p.120-146, 1948.

PEREIRA, A.R.; FERRAZ, E.S.B.; REICHARDT, K.; LIBARDI, P.L. Estimativa da evapotranspiração e da drenagem profunda em cafezais cultivados em solos podzolizados Lins e Marília. Piracicaba: CENA, 1974. 28p. (Boletim Científico, 14).

PIRES, R.C.M. Manejo da água na irrigação dos citros. Laranja, v.13, n.1, p.37260, 1992.

REEVE, J.O.; FURR, J.R. Evaporation from a shallow black pan evaporimeter as an index of oil moisture extraction by mature citrus trees. Proceedings of the American Society for Horticultural Science, v.39, p. 125-132, 1941.

REICHARDT, K. A água na produção agrícola. São Paulo: McGraw-Hill do Brasil, 1978. 119 p. 
REICHARDT, K. Dinâmica da água em solo cultivado com milho. Revista Brasileira de Ciência do Solo, v.3, p.1-5, 1979.

REICHARDT, K.; LIBARDI, P.L. An analysis of soil water movement in the field. I. Hidrological field site characterization. Piracicaba: CENA, 1974. 45 p. (Boletim Técnico, 21).

REICHARDT, K.; VIEIRA, S.R.; LIBARDI, P.L. Variabilidade espacial de solos e experimentação de campo. Revista Brasileira de Ciência do Solo, v.10, n.1, p.1-6, 1986.

REUTHER, W. Climate and citrus behavior. In: REUTHER, W. (Ed.). The citrus industry. Berkeley: University of California, 1973. v.3, cap. 4, p.98-121.

RIBEIRO, L.P. Horizontes coesos em latossolos de tabuleiros. In: SEMANA DE GEOQUíMICA, 9.; CONGRESSO DE GEOQUÍMICA DOS PAÍSES DE LínguA PORTUGUESA, 2., Porto, 1993. Porto: Universidade do Porto, Faculdade de Ciências e Laboratório Mineralógico, 1993. p.496-500. (Memórias, 3).

RODRIGUES, O. Adubação dos citros: situação dos pomares paulistas. In: YAMADA, T. (Ed.). Nutrição mineral e adubação: citros. Piracicaba: POTAFOS, 1979. p.74-79.

ROGERS, J.S.; ALLEN, L.H.; CALVERT, D.V. Evapotranspiration from a humidregion developing citrus grove with grass cover. Transactions of the ASAE, v.26, n.6, p.1778-1783, 1983.

ROSE, C.W. Agricultural physics. London: Pergamon Press, 1966. 230 p.

ROSE, C.W.; STERN, W.R. The drainage component of the water balance equation. Australian Journal of Soil Research, v.3, p.95-100, 1965.

ROSE, C.W.; STERN, W.R. Determination of withdrawal of water from soil by crop roots as a function of depth and time. Australian Journal of Soil Research, v.5, p.11-19, 1967.

SLATIER, R.O. Plant-water relationships. New York: Academic Press, 1967. $366 \mathrm{p}$. 
SMALSTRLA, A.G.; KOO, R.C.J. Effects of trickle irrigation methods and amounts of water applied on citrus yields. Proceedings of the Florida State for Horticultural Society, v.4, p.3-7, 1984.

SOUZA, L.S. Variabilidade espacial do solo em sistemas de manejo. Porto Alegre, 1992. 162p. Tese (Doutorado) - Universidade Federal do Rio Grande do Sul.

SPIEGEL, M.R. Estatística: resumo da teoria. Trad. de P. Cosentino. Rio de Janeiro: Ao Livro Técnico, 1968. 580p.

STONE, L.R.; HORTON, M.L.; OLSON, T.C. Water loss from and irrigated sorghum field: I - Water flux within bellow root zone. Agronomy Journal v.65, p.492-495, 1973.

TEIXEIRA, C.F.A. Desempenho do tensiômetro com manômetro de mercúrio, reflectômetro no domínio do tempo e sonda de nêutrons no monitoramento do teor de água no solo. Piracicaba, 2001. 115 p. Tese (Doutorado) - Escola Superior de Agricultura "Luiz de Queiroz", Universidade de São Paulo).

THORNTHWAITE, C.W. An approach a rational classification of climate.

Geographical Review, v.38, p.55-94, 1948.

THORNTHWAITE, C.W.; MATHER, J.R. The water balance. Centerton: Laboratory of Climatology, 1955. 107 p. (Publications in Climatology, v.8, n.1).

TOPP, G.C.; DAVIS, J.L.; ANNAN, A.P. Electromagnetic determination of soil water content: measurements in coaxial transmission lines. Water Resources Research, v.16, p.574-582, 1980.

TURATTI, A.L.; VILLAGRA, M.M.; POMCE, J.E.; BACHI, O.O.S.; REICHARDT, K. Variabilidade espacial do solo e sua implicação na calibração de sondas de nêutrons. Revista Brasileira de Ciência do Solo, v.14, p.259-262, 1990. VACHAUD, G.; PASSERAT, D.; SILANS. A.; BALABANIS, P.; VAUCLIN, M. Temporal stability of spatially measured soil water probability density function. Soil Science Society of America Journal, v.49, p.822-828, 1985. 
VAN BAVEL, C.H.M.; BRUST, K.J.; STIRK, G.B. Hydraulic properties of a clay loam soil and the field measurement of water uptake by roots: II. The water balance of the root zone. Soil Science Society of America Proceedings, v.32, p.317-321, 1968.

VAN BAVEL, C.H.M.; NEWMAN, J.E.; HILGEMAN, R.H. Climate and estimated water use by an orange orchard. Agricultural Meteorology, v.126, p.1-13, 1966.

VAN GENUCHTEN, M. T. A closed-form equation for predicting the hydraulic conductivity of unsaturated soils. Soil Science Society of America Journal, v.44, p.892-898, 1980.

VAN GENUCHTEN, M. T.; NIELSEN, D.R. On describing and predicting the hydraulic properties of unsaturated soils. Annales Geophysicae, v.3, n.5, p.615-627, 1985.

VAUCLIN, M.; IMBERNON, J.; VACHAND, G. Analyse comparativa de differents methodes de determination de la condutivité hydraulique des sols non saturés de la zone centre-nord du Senegal. L'Agronomie Tropicale, v.38, p.186-197, 1982.

VILLA NOVA, N. A. Principais métodos climáticos de estimativa de aplicação de água de irrigação. Piracicaba: ESALQ, Departamento de Física e Meteorologia, 1982. 22p. 


\section{APÊNDICES}




\section{APÊNDICE 1}

\section{Histórico do Pomar de Citros (Laranja Valência)}

Data de plantio: março de 1991.

Espaçamento utilizado: $4 \times 8$.

Número de plantas no pomar (Valência): 196 plantas.

Porta-enxerto: Limão Cravo

Adubação de plantio: $300 \mathrm{~g}$ de Superfosfato Simples e $500 \mathrm{~g}$ de calcário/cova.

Adubações posteriores: $50 \mathrm{~g}$ de uréia/planta a partir do $4^{\circ}$ mês de idade, 4 vezes ao ano, nos meses de setembro, novembro, janeiro e março até os 2 anos de idade; $100 \mathrm{~g}$ de uréia $+50 \mathrm{~g}$ de Cloreto de potássio/planta até os 4 anos de idade; $500 \mathrm{~g}$ da fórmula 12:06:12 por planta até os 7 anos; atualmente 1,0 kg/planta da fórmula 12:06:12.

Tratamentos fitossanitários: Controle de ácaros, 2 vezes por ano.

Controle da mosca das frutas, 2 vezes por ano.

Controle de Invasoras: Capina até os 4 anos de idade e atualmente com aplicações de herbicida sistêmico na linha e roçagem com trator nas entrelinhas. Aplicação do herbicida em 3 vezes ao ano com roçagem.

Adubação foliar: por ocasião do controle de ácaros com micronutrientes: Zn, $\mathrm{Cu}, \mathrm{Mn}$ e B.

Também aplicação de uréia e cloreto de potássio. 


\section{APÊNDICE 2}

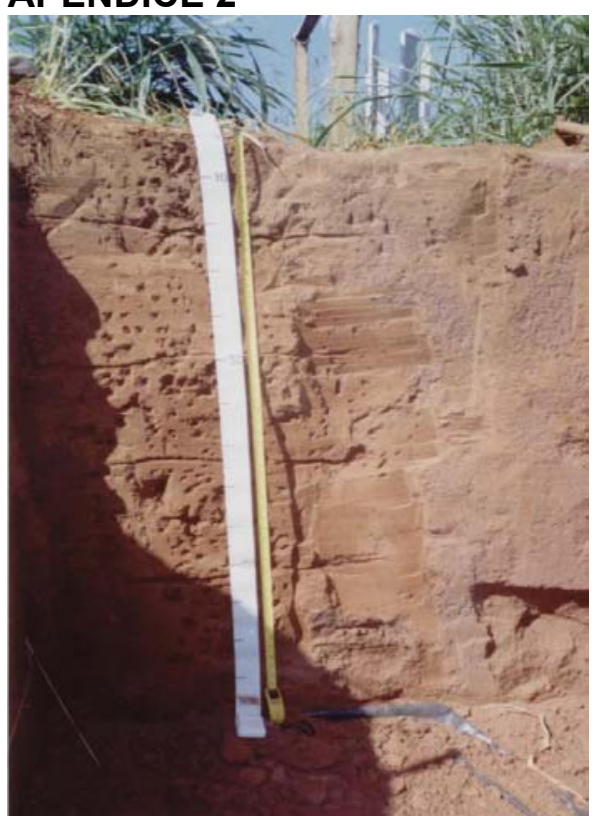

Fotografia do perfil classificado.

A caracterização morfológica do solo foi descrita em trincheira aberta na área próxima ao experimento e apresenta:

Ap 0-5 cm;

bruno avermelhado escuro(5YR 3/4, úmido); franco arenosa; estrutura modificada pelo uso agrícola, composto por blocos subangulares de tamanho variável; moderada a forte, não plástico e ligeiramente pegajoso; transição abrupta; plana.

$A_{2}$ 5-22 cm;

bruno avermelhado escuro(5YR 3/4, úmido); franco arenosa; estrutura modificada pelo uso agrícola composta por blocos subangulares de tamanho variável; moderada, ligeiramente plástico e ligeiramente pegajoso; transição clara; plana.

$\mathrm{Bw}_{1}$ 22-48 cm; vermelho escuro(2,5YR 3/6, úmido); franco argilo arenosa; blocos subangulares de tamanho variável; 
moderada, plástico e muito pegajoso; transição clara; plana.

$\mathrm{Bw}_{2}$ 48-72 cm; vermelho escuro(2,5YR 3/6, úmido); franco argiloso arenosa; moderada; blocos subangulares; plástico e pegajoso. carvões pequenos esparsos; transição gradual; plana.

$\mathrm{Bw}_{3} \mathbf{7 2 - 1 0 0} \mathrm{cm}$; vermelho escuro(2,5YR 3/6, úmido); franco argiloso arenosa; moderada a forte; blocos subangulares; plástico e ligeiramente pegajoso. carvões pequenos esparsos; transição gradual; plana.

$\mathrm{Bw}_{4}$ 100-135 cm; vermelho escuro(2,5YR 3/6, úmido); franco argiloso arenosa; moderada; blocos subangulares; plástico e pegajoso. carvões pequenos esparsos; transição gradual; plana.

$\mathrm{Bw}_{5} 135+\mathrm{cm}$; vermelho escuro(2,5YR 3/6, úmido); franco argiloso arenosa; moderada; blocos subangulares; plástico e pegajoso. carvões pequenos esparsos.

\section{Observações:}

1) Raízes: muitas, médias e finas no $A p$; comuns e finas no $B w_{1}$; raras e muito finas nos demais horizontes.

2) Porosidade: são encontrados poros muito pequenos, comuns nos horizontes Ap e Bw e poros pequenos médios, abundantes nos demais horizontes.

3) $O$ relevo local é levemente ondulado e o regional também. 
Descrição morfológica do perfil da trincheira amostrada.

Classificação: Latossolo Vermelho-Amarelo Distrófico argissólico textura média A moderado.

Uso atual: Pomar de citros, Clima: CW.

\begin{tabular}{|c|c|c|c|c|c|c|c|c|c|c|c|c|c|c|}
\hline \multirow[t]{2}{*}{ Hor } & \multirow{2}{*}{$\begin{array}{l}\text { Prof. } \\
\mathrm{cm}\end{array}$} & \multirow[t]{2}{*}{ Cor } & \multirow[t]{2}{*}{ Textura } & \multicolumn{3}{|c|}{ Estrutura } & \multicolumn{4}{|c|}{ Consistência } & \multicolumn{2}{|c|}{ Transição } & \multicolumn{2}{|c|}{ Cerosidade } \\
\hline & & & & Tipo & Classe & Grau & Seca & Úmida & Molhada & & Nitidez & Topog. & Grau & Quant. \\
\hline $\mathrm{Ap}$ & $0-5$ & $5 Y R$ 3/4 & $\begin{array}{l}\text { Franco } \\
\text { arenosa }\end{array}$ & $\begin{array}{l}\text { Blocos } \\
\text { Suban. }\end{array}$ & Média & $\begin{array}{l}\text { Moderada } \\
\text { a forte }\end{array}$ & $\begin{array}{l}\text { Lig. } \\
\text { dura }\end{array}$ & $\begin{array}{l}\text { Muito } \\
\text { friável }\end{array}$ & $\begin{array}{l}\text { Não } \\
\text { Plástico }\end{array}$ & $\begin{array}{l}\text { Lig. } \\
\text { Pegajosa }\end{array}$ & Abrupta & Plana & Ausente & ----- \\
\hline$A_{2}$ & $5-22$ & 5YR 3/4 & $\begin{array}{l}\text { Franco } \\
\text { arenosa }\end{array}$ & $\begin{array}{l}\text { Blocos } \\
\text { Suban. }\end{array}$ & $\begin{array}{l}\text { Média a } \\
\text { grande }\end{array}$ & Moderada & Dura & $\begin{array}{l}\text { Muito } \\
\text { friável }\end{array}$ & $\begin{array}{l}\text { Lig. } \\
\text { Plástico }\end{array}$ & $\begin{array}{l}\text { Lig. } \\
\text { pegajosa }\end{array}$ & Clara & Plana & Ausente & ----- \\
\hline $\mathrm{Bw}_{1}$ & $22-48$ & 2,5YR 3/6 & $\begin{array}{l}\text { Franco } \\
\text { argilo } \\
\text { arenosa }\end{array}$ & $\begin{array}{l}\text { Blocos } \\
\text { Suban. }\end{array}$ & $\begin{array}{l}\text { Média a } \\
\text { grande }\end{array}$ & Moderada & $\begin{array}{l}\text { Muito } \\
\text { dura }\end{array}$ & $\begin{array}{l}\text { Muito } \\
\text { friável }\end{array}$ & Plástico & $\begin{array}{l}\text { Muito } \\
\text { pegajosa }\end{array}$ & Clara & Plana & Ausente & ----- \\
\hline $\mathrm{Bw}_{2}$ & $48-72$ & 2,5YR 3/6 & $\begin{array}{l}\text { Franco } \\
\text { argilo } \\
\text { arenosa }\end{array}$ & $\begin{array}{l}\text { Blocos } \\
\text { Suban. }\end{array}$ & $\begin{array}{l}\text { Média a } \\
\text { Grande }\end{array}$ & Moderada & $\begin{array}{l}\text { Lig. a } \\
\text { Dura }\end{array}$ & $\begin{array}{l}\text { Muito } \\
\text { friável }\end{array}$ & Plástico & Pegajosa & Gradual & Plana & Ausente & $\ldots \ldots$. \\
\hline $\mathrm{Bw}_{3}$ & $72-100$ & 2,5YR 3/6 & $\begin{array}{l}\text { Franco } \\
\text { argilo } \\
\text { arenosa }\end{array}$ & $\begin{array}{l}\text { Blocos } \\
\text { Suban. }\end{array}$ & Média & $\begin{array}{l}\text { Moderada } \\
\text { a forte }\end{array}$ & $\begin{array}{l}\text { Lig. } \\
\text { dura }\end{array}$ & $\begin{array}{l}\text { Muito } \\
\text { friável }\end{array}$ & Plástico & $\begin{array}{l}\text { Lig. } \\
\text { pegajosa }\end{array}$ & Gradual & Plana & Ausente & $\ldots \ldots$. \\
\hline $\mathrm{Bw}_{4}$ & $100-135$ & 2,5YR 3/6 & $\begin{array}{l}\text { Franco } \\
\text { argilo } \\
\text { arenosa }\end{array}$ & $\begin{array}{l}\text { Blocos } \\
\text { Suban. }\end{array}$ & Pequena & Moderada & $\begin{array}{l}\text { Lig. } \\
\text { dura }\end{array}$ & $\begin{array}{l}\text { Muito } \\
\text { friável }\end{array}$ & Plástico & Pegajosa & Gradual & Plana & Ausente & $\ldots \ldots \ldots$ \\
\hline $\mathrm{Bw}_{5}$ & $135+$ & 2,5YR 3/6 & $\begin{array}{l}\text { Franco } \\
\text { argilo } \\
\text { arenosa }\end{array}$ & $\begin{array}{l}\text { Blocos } \\
\text { Suban. }\end{array}$ & Pequena & Moderada & $\begin{array}{l}\text { Lig. } \\
\text { dura }\end{array}$ & $\begin{array}{l}\text { Muito } \\
\text { friável }\end{array}$ & Plástico & Pegajosa & ----- & ----- & Ausente & $\ldots \ldots \ldots$ \\
\hline
\end{tabular}

Obs.: O relevo local é levemente ondulado e o regional também.

Drenagem boa. 
Resultado das Análises Químicas.

\begin{tabular}{llllllllllllll}
\hline Idendif. & $\mathrm{pH}$ & $\mathrm{M} . \mathrm{O}$. & $\mathrm{P}$ & $\mathrm{S}$ & $\mathrm{K}$ & $\mathrm{Ca}$ & $\mathrm{Mg}$ & $\mathrm{Al}$ & $\mathrm{H}+\mathrm{Al}$ & $\mathrm{SB}$ & $\mathrm{T}$ & $\mathrm{V}$ & $\mathrm{m}$ \\
\cline { 2 - 12 } & $\mathrm{CaCl}_{2}$ & $\mathrm{~g} \mathrm{dm}^{-3}$ & $\mathrm{mg} \mathrm{dm}^{-3}$ & & \multicolumn{2}{c}{$\mathrm{mmol}_{\mathrm{c}} \mathrm{dm}^{-3}$} & & & & & & & \\
\hline $\mathrm{A}_{\mathrm{P}}$ & 5.3 & 24 & 12 & 63 & 1.1 & 23 & 9 & 0 & 20 & 33.1 & 53.1 & 62 & 0 \\
$\mathrm{~A}_{2}$ & 4.5 & 15 & 5 & 10 & 1.1 & 10 & 4 & 3 & 22 & 15.1 & 37.1 & 41 & 17 \\
$\mathrm{Bw}_{1}$ & 4.3 & 7 & 3 & 12 & 0.4 & 5 & 4 & 3 & 18 & 9.4 & 27.4 & 34 & 24 \\
$\mathrm{Bw}_{2}$ & 4.4 & 7 & 3 & 22 & 0.3 & 6 & 4 & 3 & 18 & 10.3 & 28.3 & 36 & 23 \\
$\mathrm{Bw}_{3}$ & 4.6 & 7 & 2 & 24 & 0.2 & 5 & 3 & 0 & 15 & 8.2 & 23.2 & 35 & 0 \\
$\mathrm{Bw}_{4}$ & 4.8 & 7 & 2 & 19 & 0.4 & 6 & 2 & 0 & 15 & 8.4 & 23.4 & 36 & 0 \\
$\mathrm{Bw}_{5}$ & 5.2 & 8 & 2 & 30 & 0.2 & 8 & 1 & 0 & 12 & 9.2 & 21.2 & 43 & 0 \\
\hline
\end{tabular}

Resultado da Análise Ataque Sulfúrico

\begin{tabular}{|c|c|c|c|c|c|c|c|}
\hline \multirow[t]{2}{*}{ Identific. } & $\mathrm{SiO}_{2}$ & $\mathrm{Al}_{2} \mathrm{O}_{3}$ & $\mathrm{Fe}_{2} \mathrm{O}_{3}$ & $\mathrm{TiO}_{2}$ & $\mathrm{MnO}$ & \multirow[t]{2}{*}{$\mathrm{Ki}$} & \multirow[t]{2}{*}{$\mathrm{Kr}$} \\
\hline & $\%$ & & & & & & \\
\hline$A_{P}$ & 5.1 & 3.62 & 2.31 & 0.65 & 0.03 & 2.4 & 1.70 \\
\hline$A_{2}$ & 5.8 & 4.28 & 2.85 & 0.77 & 0.03 & 2.3 & 1.62 \\
\hline $\mathrm{Bw}_{1}$ & 7.5 & 7.09 & 3.61 & 0.78 & 0.03 & 1.8 & 1.36 \\
\hline $\mathrm{Bw}_{2}$ & 7.8 & 6.88 & 3.70 & 0.88 & 0.02 & 1.93 & 1.43 \\
\hline $\mathrm{Bw}_{3}$ & 9.9 & 7.08 & 3.86 & 0.88 & 0.02 & 2.38 & 1.76 \\
\hline $\mathrm{Bw}_{4}$ & 7.7 & 6.80 & 3.58 & 0.82 & 0.01 & 1.93 & 1.44 \\
\hline $\mathrm{BW}_{5}$ & 8.9 & 6.84 & 3.72 & 0.80 & 0.01 & 2.21 & 1.64 \\
\hline
\end{tabular}




\section{APÊNDICE 3}

Croqui da disposição das plantas de citros nas duas transeções monitoradas. A seta indica a localização da planta em que o balanço foi realizado por profundidade e distância do tronco.

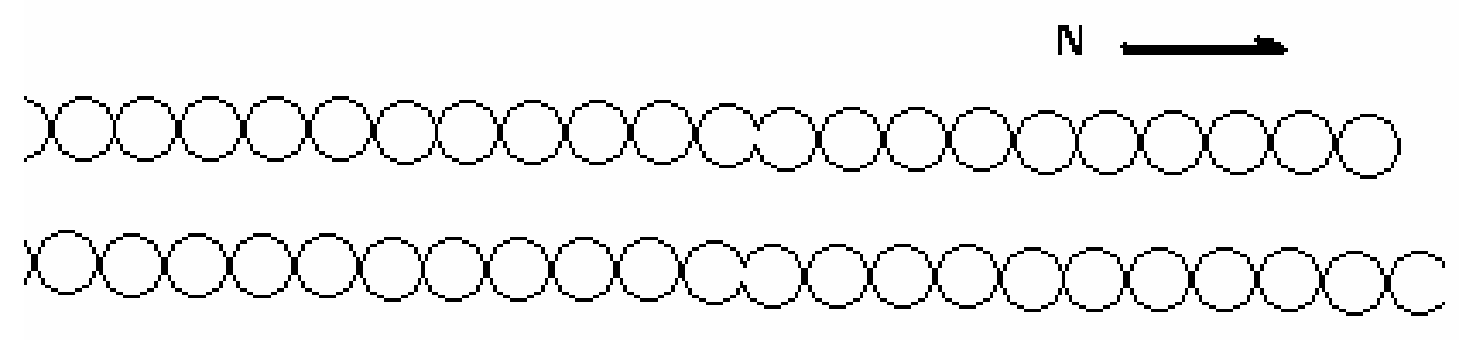

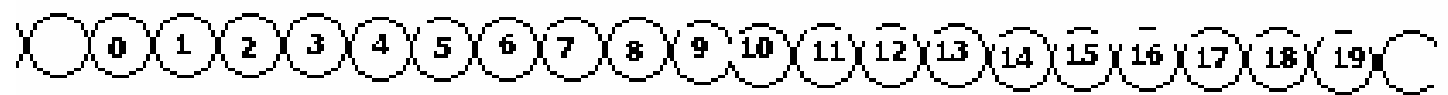

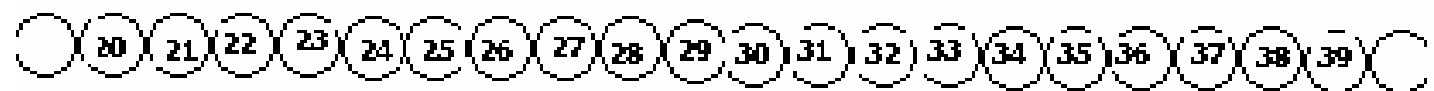

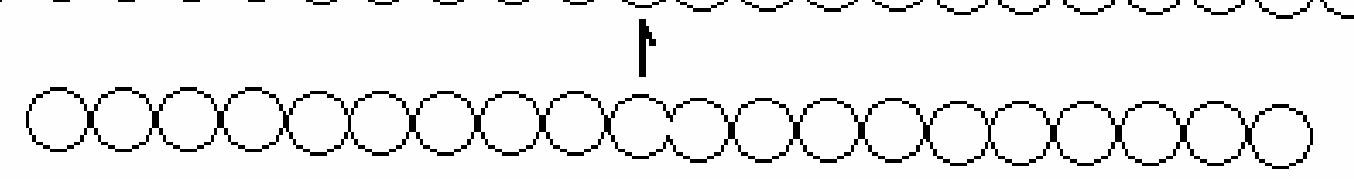

0000000

\section{AEROPORTO}




\section{APÊNDICE 4}

Curvas características da água no solo para as profundidades avaliadas.
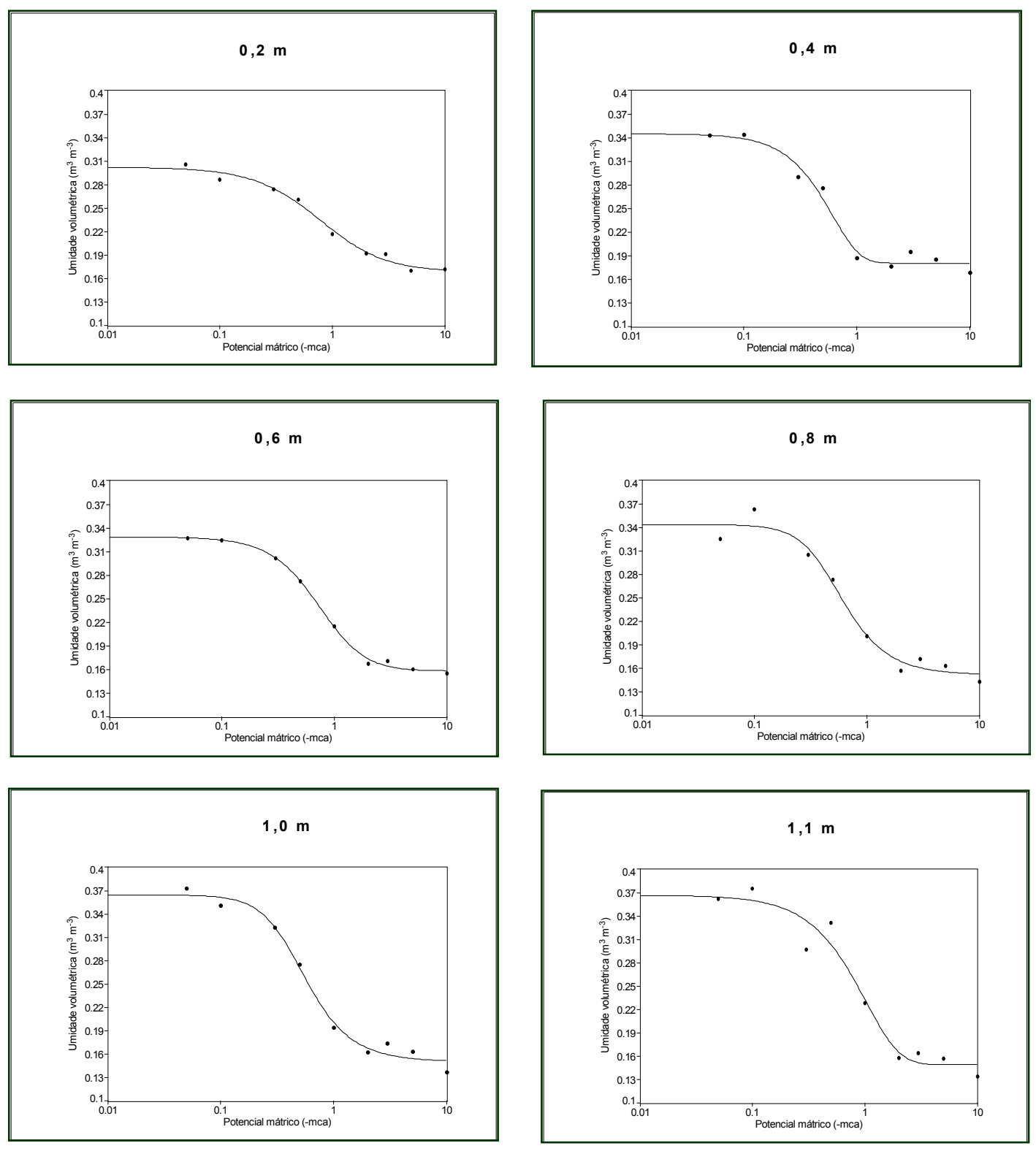


\section{APÊNDICE 5}

Umidade volumétrica obtida durante o período seco em direção à entrelinha.


Distância de 2,00 $\mathrm{m}$ do tronco em direção à linha

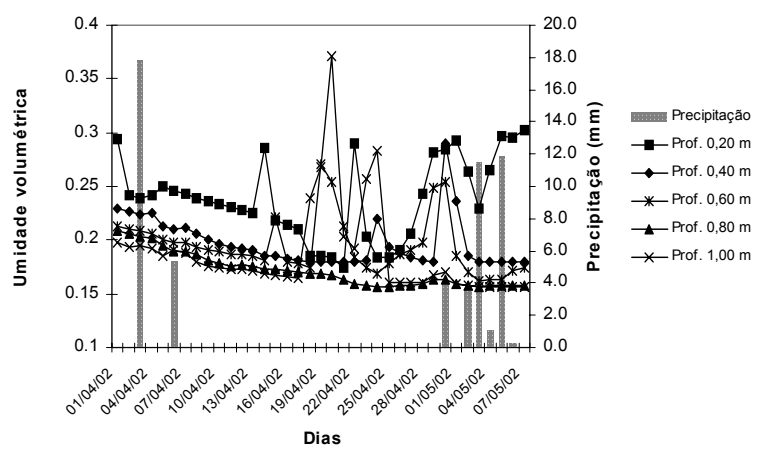




\section{APÊNDICE 6}

Umidade volumétrica obtida durante o período úmido em direção à entrelinha.

Distância de $0,40 \mathrm{~m}$ do tronco em dire ção à entre linha

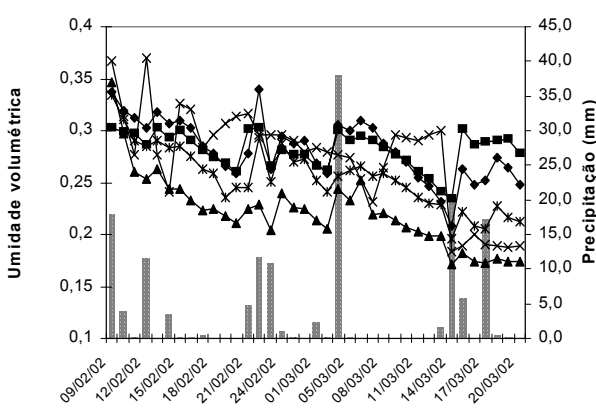

Distância de $1,20 \mathrm{~m}$ do tronco em dire ção à entrelinha

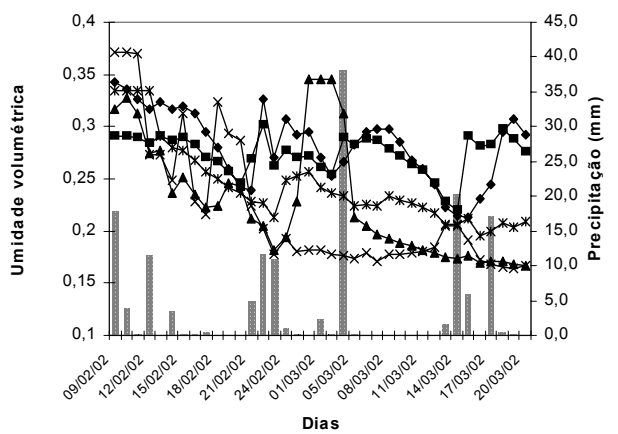

Distância de 2,00 m do tronco em direção à entre linha

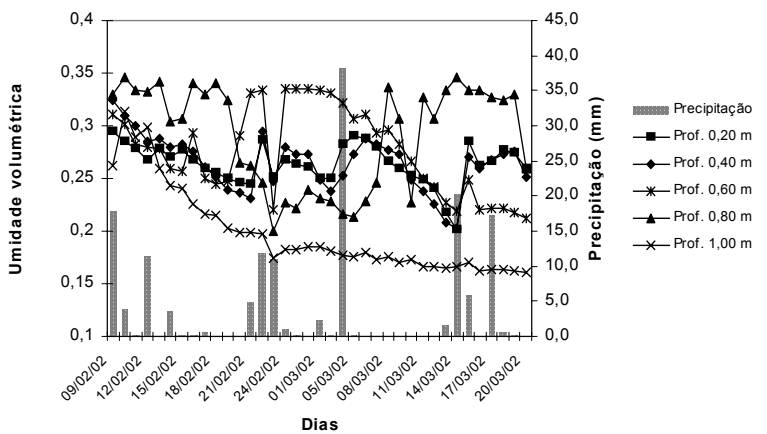

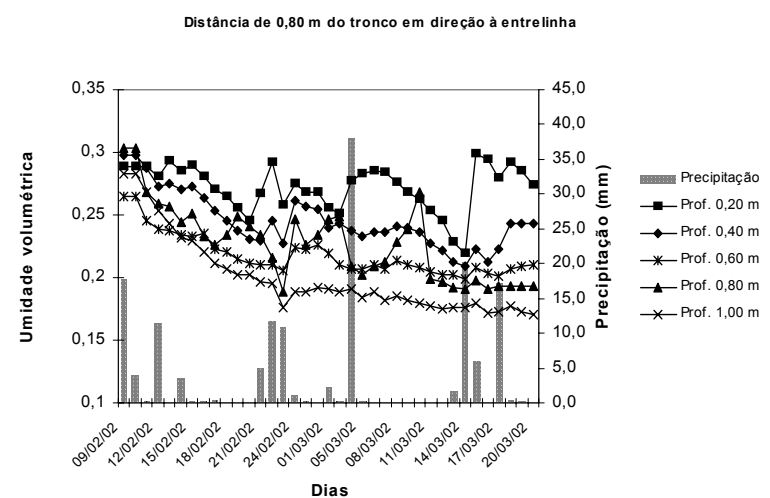

Distância de 1,60 m do tronco em direção à entre linha

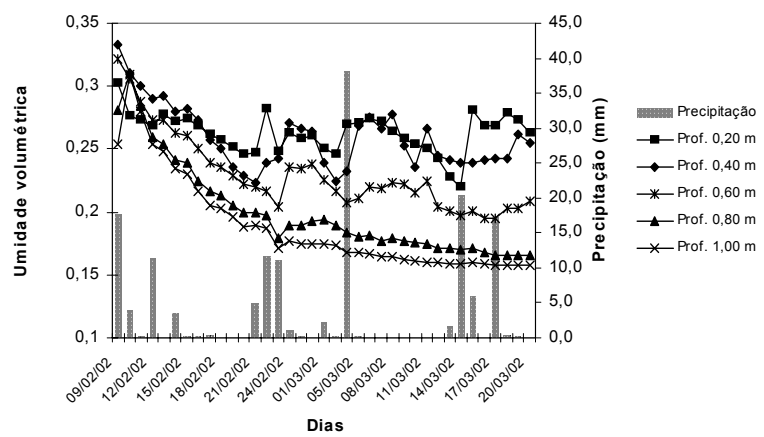




\section{APÊNDICE 7}

Umidade volumétrica obtida durante o período úmido em direção à linha.
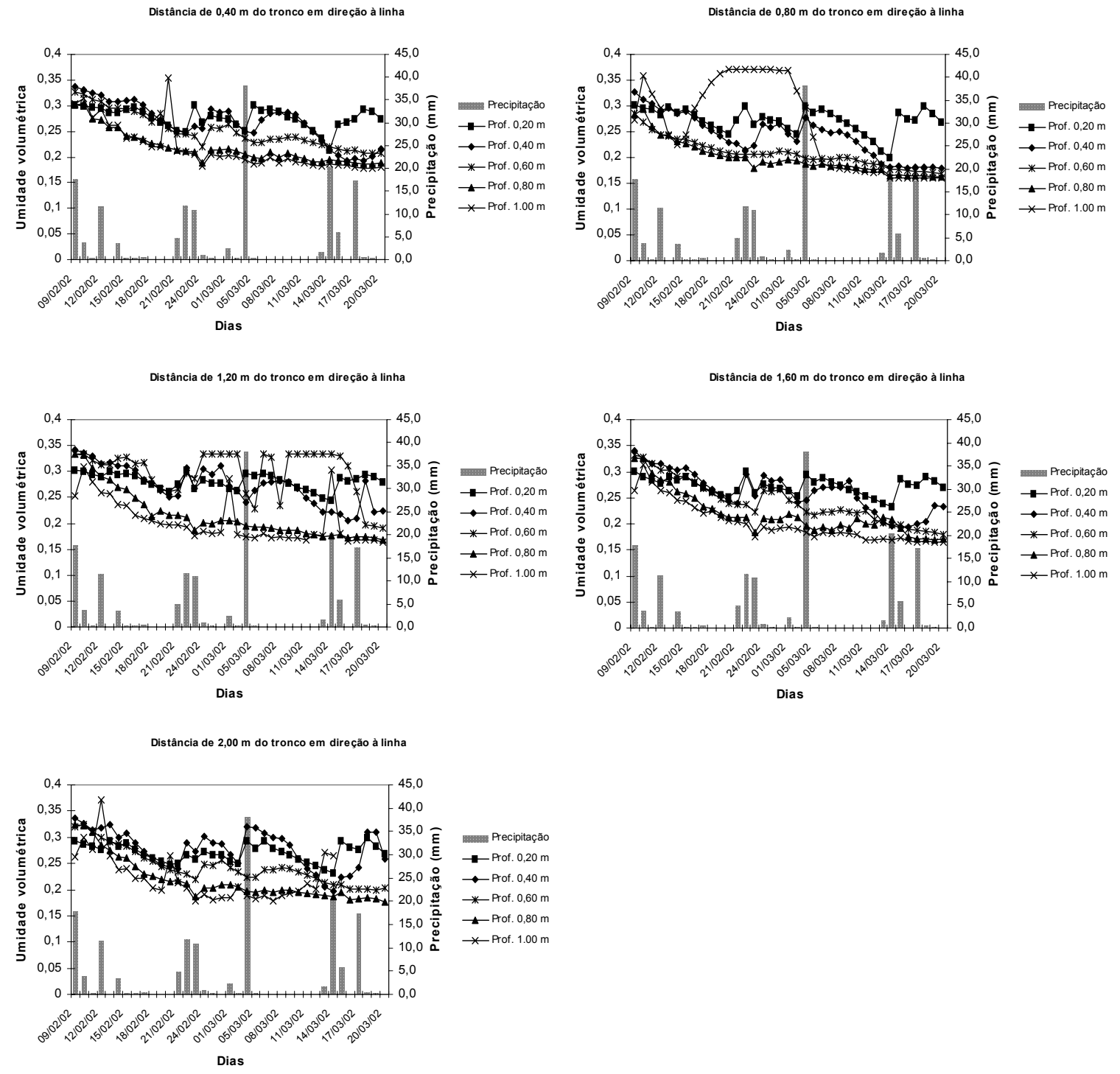


\section{APÊNDICE 8}

Umidade volumétrica obtida durante o período seco em direção à linha.

Distância de $0,40 \mathrm{~m}$ do tronco em dire çăo à linha

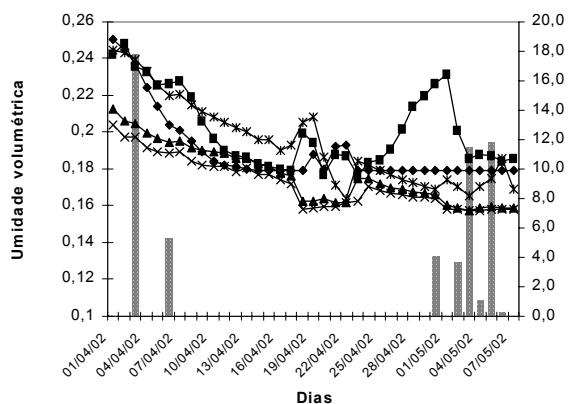

Distância de $1,20 \mathrm{~m}$ do tronco em dire ção à linha

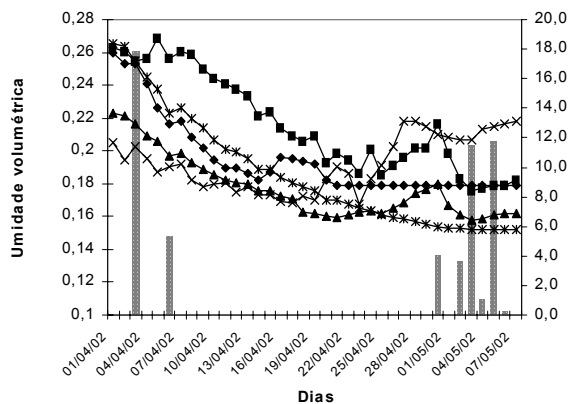

Distância de $2,00 \mathrm{~m}$ do tronco em dire ção à linha

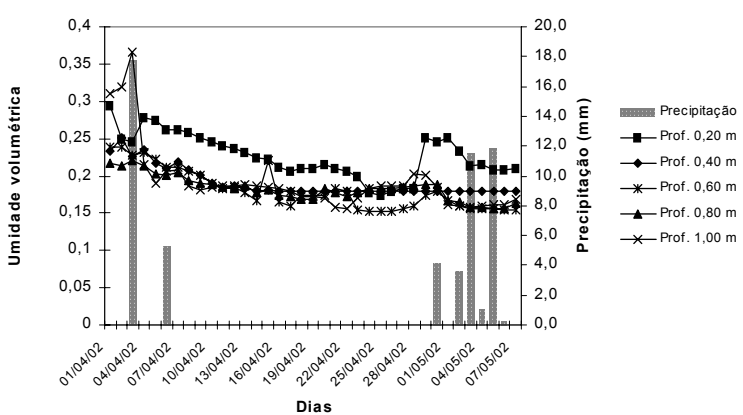

Distância de $0,80 \mathrm{~m}$ do tronco em direçăo à linha
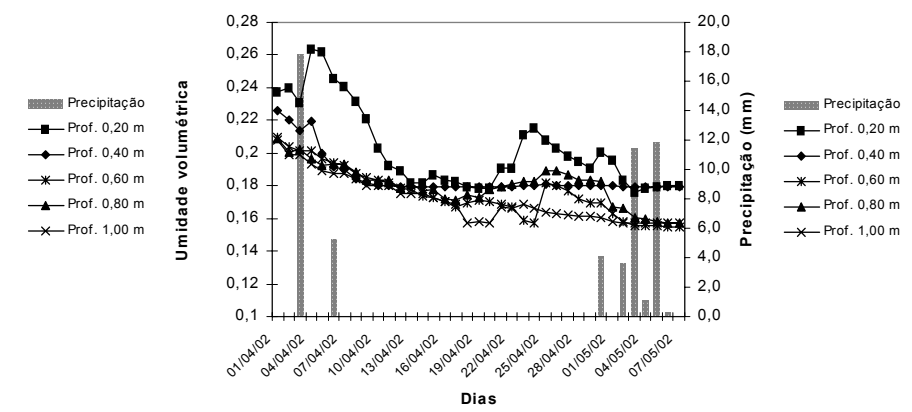

Distância de $1,60 \mathrm{~m}$ do tronco em direção à linha

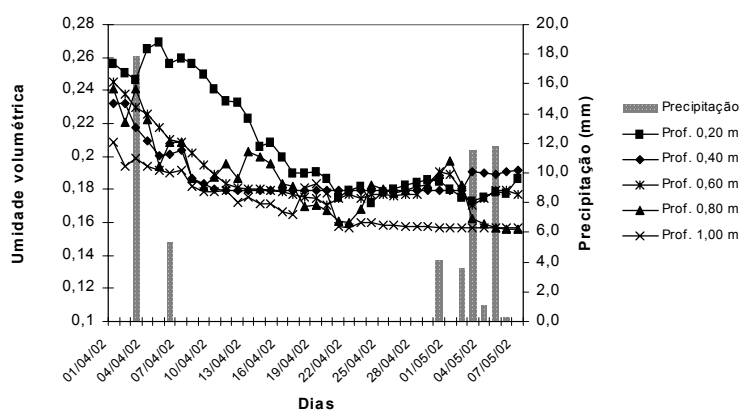




\section{APÊNDICE 9}

Curva de calibração da Sonda de Nêutrons obtida pela relação entre 223 pares de dados, $\mathbf{x} \rightarrow$ contagem relativa $\mathbf{x} \mathbf{y} \rightarrow$ umidade gravimétrica.

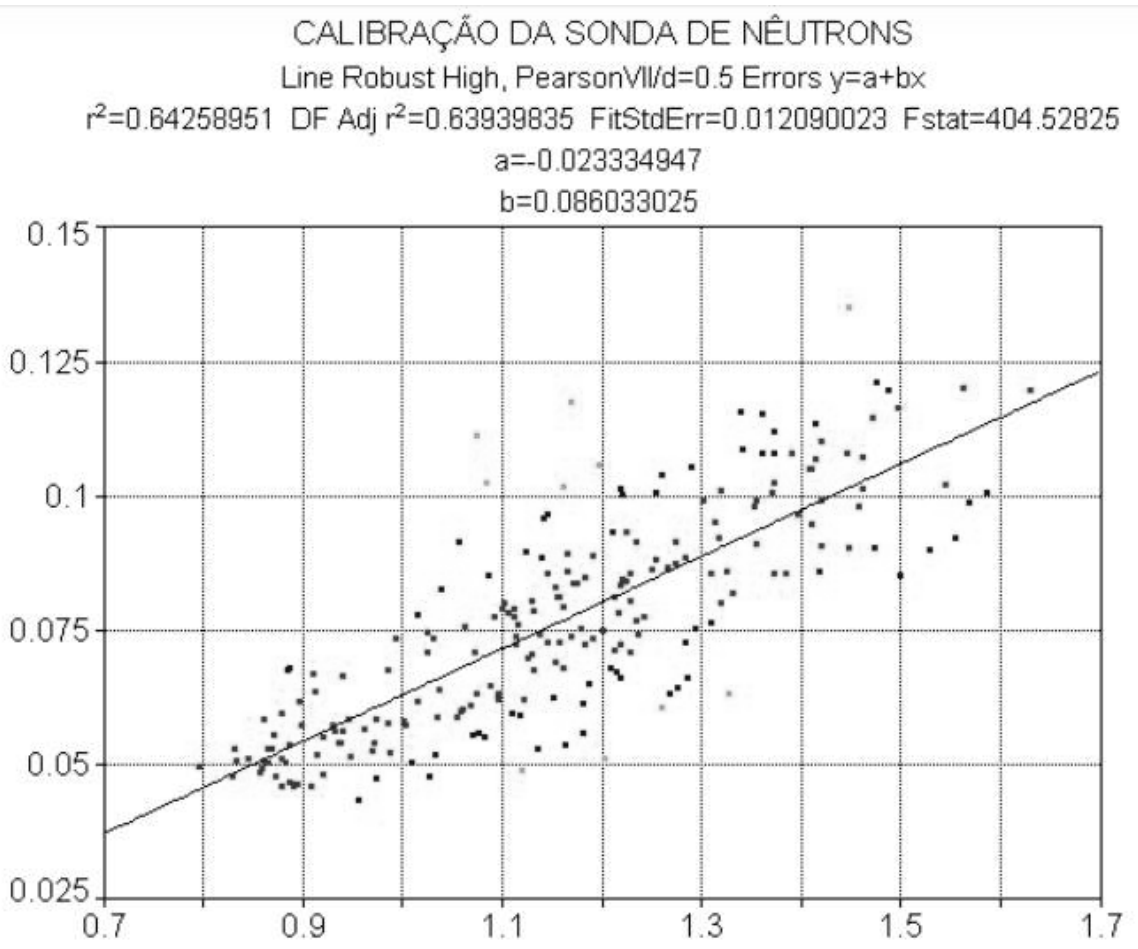




\section{APÊNDICE 10}

Resultados da análise granulométrica realizada em amostras de solo coletadas em 8 pontos* $^{*}$ das transeções.

\begin{tabular}{|c|c|c|c|c|c|c|c|c|}
\hline Profundidade & $\begin{array}{c}\text { Areia } \\
\text { total } \%\end{array}$ & Silte \% & Argila \% & $\% A M G$ & $\% A G$ & $\%$ AM & $\% A F$ & $\%$ AMF \\
\hline $0-10$ & 79,40 & 5,20 & 15,40 & 0,72 & 2,86 & 22,30 & 40,94 & 12,58 \\
\hline $10-20$ & 77,60 & 4,20 & 18,20 & 0,50 & 2,07 & 20,59 & 41,56 & 12,87 \\
\hline $20-30$ & 74,57 & 4,71 & 20,71 & 0,39 & 1,90 & 19,11 & 40,50 & 12,68 \\
\hline $30-40$ & 71,14 & 4,29 & 24,57 & 0,33 & 1,94 & 17,28 & 38,47 & 13,12 \\
\hline $40-50$ & 69,57 & 4,57 & 25,86 & 0,34 & 1,69 & 16,60 & 37,75 & 13,20 \\
\hline $50-60$ & 68,86 & 4,57 & 26,57 & 0,39 & 1,81 & 16,85 & 37,17 & 12,65 \\
\hline $60-70$ & 69,00 & 5,00 & 26,00 & 0,35 & 1,85 & 16,66 & 37,67 & 12,46 \\
\hline $70-80$ & 69,00 & 5,00 & 26,00 & 0,38 & 1,85 & 16,78 & 37,64 & 12,35 \\
\hline $80-90$ & 70,14 & 4,43 & 25,43 & 0,39 & 1,89 & 16,80 & 37,65 & 13,41 \\
\hline $90-100$ & 69,38 & 4,25 & 26,38 & 0,41 & 1,89 & 16,50 & 37,14 & 13,45 \\
\hline $100-110$ & 68,75 & 4,88 & 26,38 & 0,40 & 1,81 & 16,77 & 35,67 & 14,09 \\
\hline
\end{tabular}

${ }^{*}$ Pontos coletados: 0, 20, 29, 33, 34, 36, 37 e 38. 